University of Rhode Island

DigitalCommons@URI

Open Access Master's Theses

1997

\title{
LOCAL EFFORTS FOR GROUNDWATER PROTECTION: AN ASSESSMENT OF STRATEGIES WITHIN THE STATE AND FEDERAL CONTEXT SOUTH KINGSTOWN, RHODE ISLAND
}

Kathleen M. Murray

University of Rhode Island

Follow this and additional works at: https://digitalcommons.uri.edu/theses

\section{Recommended Citation}

Murray, Kathleen M., "LOCAL EFFORTS FOR GROUNDWATER PROTECTION: AN ASSESSMENT OF

STRATEGIES WITHIN THE STATE AND FEDERAL CONTEXT SOUTH KINGSTOWN, RHODE ISLAND" (1997). Open Access Master's Theses. Paper 564.

https://digitalcommons.uri.edu/theses/564

This Thesis is brought to you for free and open access by DigitalCommons@URI. It has been accepted for inclusion in Open Access Master's Theses by an authorized administrator of DigitalCommons@URI. For more information, please contact digitalcommons-group@uri.edu. 
LOCAL EFFORTS FOR GROUNDWATER PROTECTION:

An Assessment of Strategies within the State and Federal ConteXt

SOUTH KINGSTOWN, RHODE ISLAND

BY

KATHLEEN M. MURRAY

A Research Project Submitted In

Partial Fulfillment of the Requirements for the

Degree of

Master of Community Planning

UNIVERSITY OF RHODE ISLAND

MAY 1997 
MASTER OF COMMUNITY PLANNING

RESEARCH PROJECT

OF

KATHLEEN M. MURRAY

Approved:

Major Professor

Acknowledged:

Director
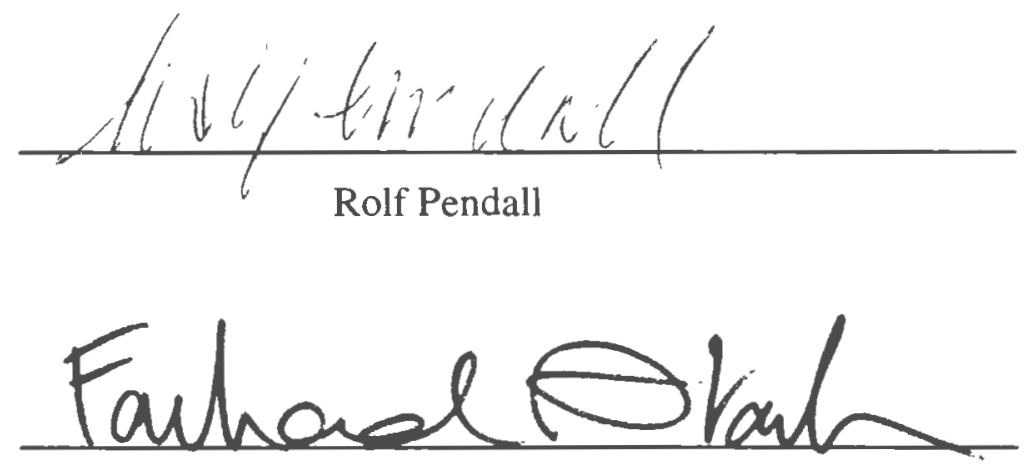

Farhad Atash 


\section{ACKNOWLEDGEMENTS}

Sincere thanks go to several individuals who were influential in this project. First and foremost my thanks to Professor Rolf Pendall who initially encouraged me to pursue a topic on groundwater protection. I especially appreciate his interest in my work and his continuous availability for questions at any time. Many thanks to Professor Howard Foster for his input and efforts in seeing this project to completion. Finally, I am most indebted to Raymond Nickerson of the South Kingstown Planning Department. In addition to reading and re-reading this project and many others, my days spent sharing his office supplemented my academic education in ways invaluable.

Thanks to my family and my many good friends who tolerated me, encouraged me, and helped me immensely during these two years at URI. 


\section{Table of Contents}

I. INTRODUCTION ................................................................................................................. 1

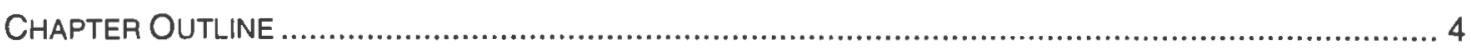

II: LITERATURE REVIEW: WELLHEAD PROTECTION IN CONTEXT...................................... 6

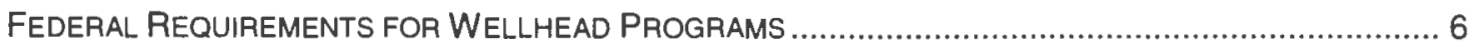

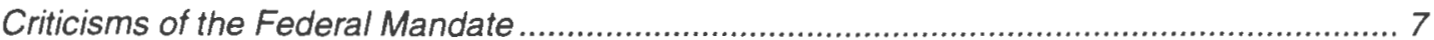

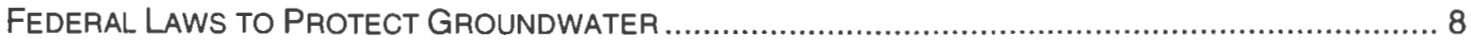

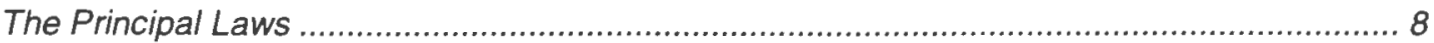

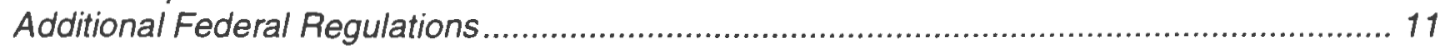

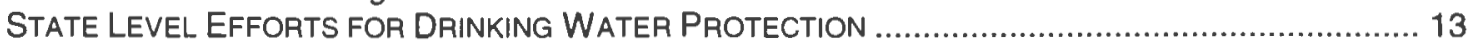

The Rhode Island Wellhead Protection Program ............................................................ 13

State Laws for Groundwater Protection .............................................................................. 19

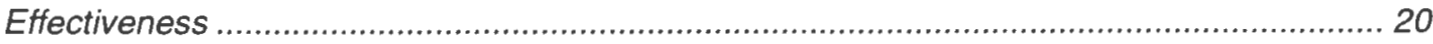

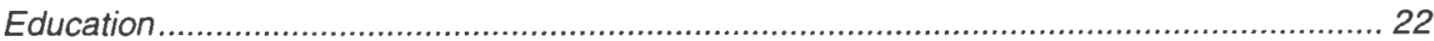

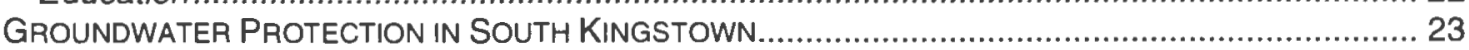

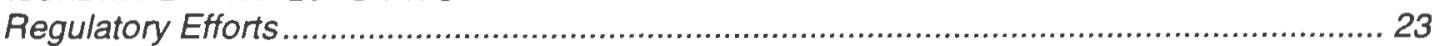

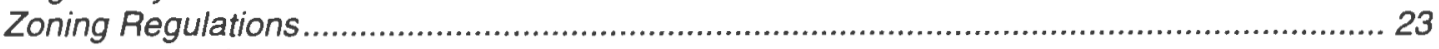

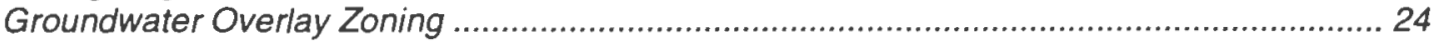

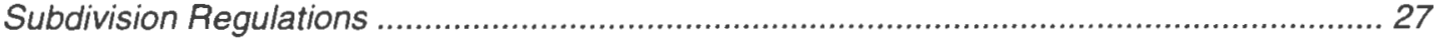

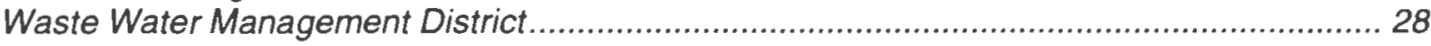

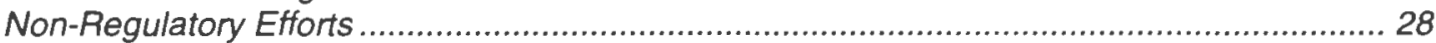

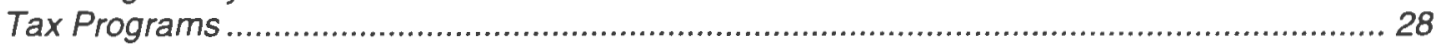

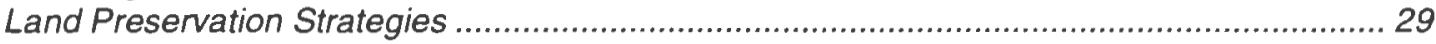

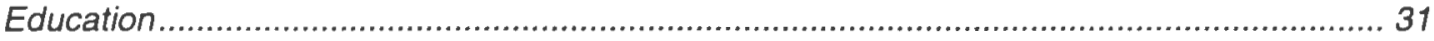

III: SUMMARY OF THE SOUTH KINGSTOWN WELLHEAD PROTECTION PLAN.................. 33

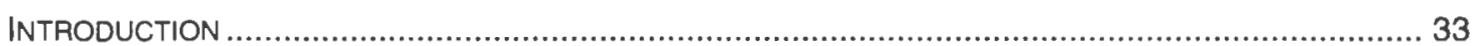

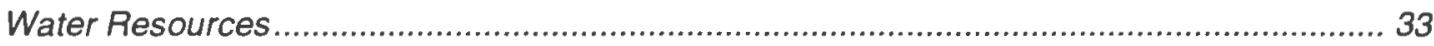

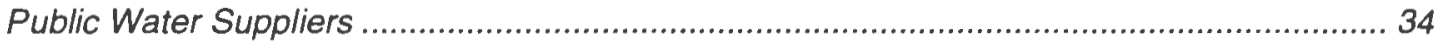

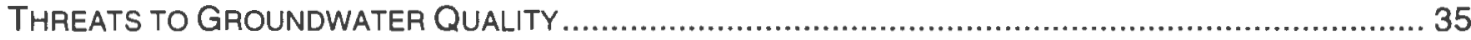

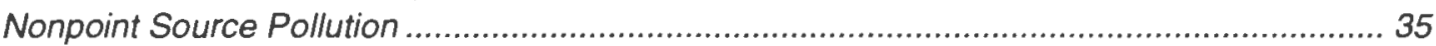

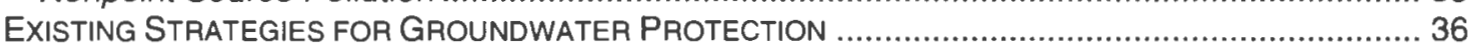

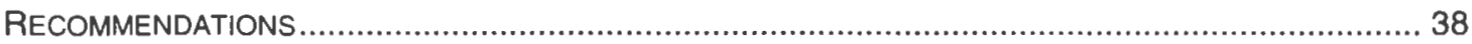

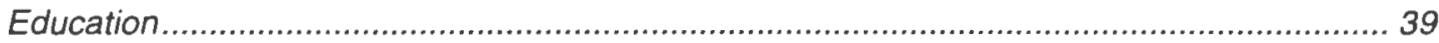

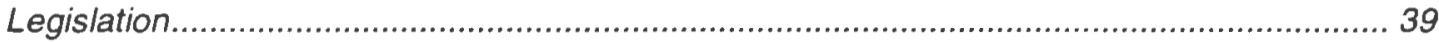

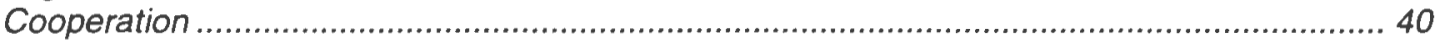

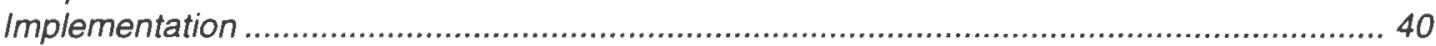

IV: LOCAL IMPLEMENTATION OF GROUNDWATER PROTECTION ................................... 42

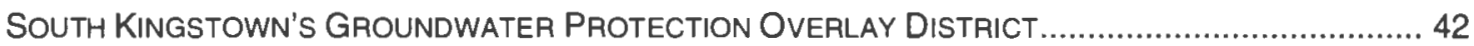

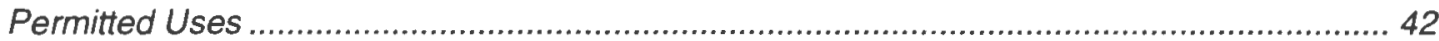

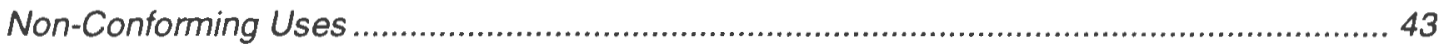

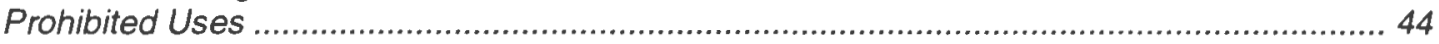

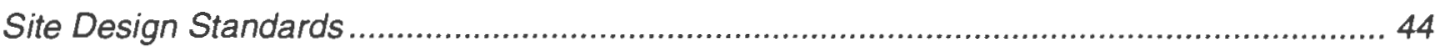

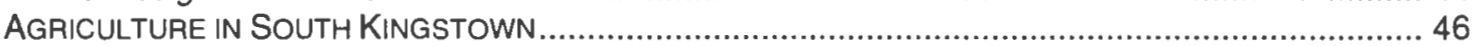

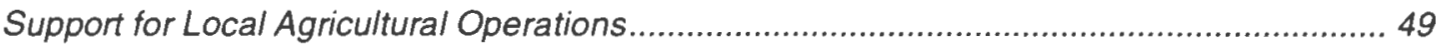

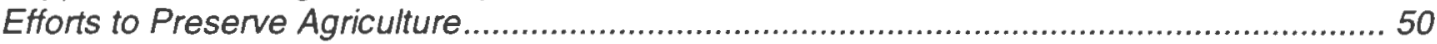

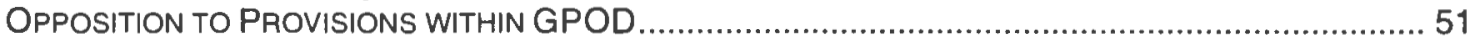

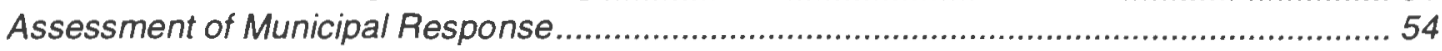

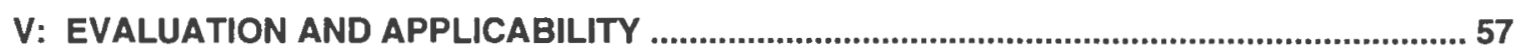

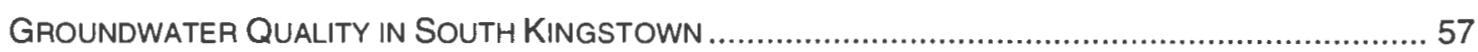


APPLICABILITY OF MEASURES TO OTHER PAWCATUCK WATERSHEd COMMUNITIES ..................... 59

Application of Regulatory Techniques ..............................................................61 61

Application of Non-Regulatory Techniques .......................................................62

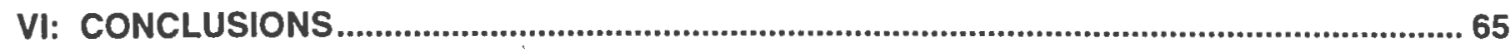

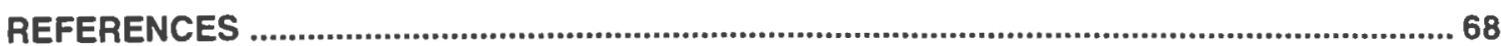

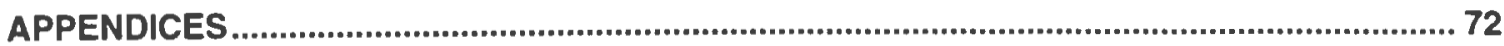

ApPENDIX A: TOWN Of SOUTH KINGSTOWN, RI WELlHEAd PROTECTION PLAN

Appendix B: Groundwater Protection OVerlay District, Article 20 of the South

KINGSTOWN ZONING ORDINANCE 


\section{Introduction}

The 1986 amendments to the Federal Safe Drinking Water Act (SDWA) of 1974 (42 USC 300 fe seq.) placed additional requirements on states and municipalities to protect water supplies in a new way: The amendments mandate states to adopt wellhead protection programs. The Rhode Island Department of Environmental Management (DEM) is carrying out these requirements and, following federal guidelines, has adopted a program entailing requirements for most the 39 Rhode Island communities. Entitled the Rhode Island Wellhead Protection Program, DEM identified steps that State level departments, local water suppliers, and municipalities must follow to ensure continued potability of the state's drinking water supplies. To comply with state regulations, the Town of South Kingstown, with seventeen wellhead protection areas, must inventory threats to wells and develop a management plan to prevent future contamination of supplies.

Even before amendments to the Safe Drinking Water Act and the mandated wellhead program, South Kingstown had initiated efforts to protect water supplies. Large-lot residential zones (two and five acre minimum lot size) were established in regions of town overlying groundwater aquifers to hinder high density residential development. The Groundwater Protection Overlay District (GPOD) was established in 1991 to regulate uses within the town's three groundwater aquifers, from which 50 percent of drinking water supplies are obtained. Central to the legislation are uses prohibited from the overlay zones, and site design standards for uses which could 
potentially affect groundwater supplies (Town of South Kingstown Zoning Ordinance, Sections 2021 and 2030).

Current land uses overlying aquifers include open space preserves, residential, commercial, and industrial development, and agricultural uses, which are permitted by right in all zoning districts. All land uses except strict conservation areas will threaten groundwater supplies, and it is commonly noted that agricultural uses pose some the greatest risks to groundwater supplies (Rhode Island Department of Environmental Management 1992, Adler, Landman, and Cameron 1993, Connecticut Department of Environmental Protection 1989, Jeer 1995b, Witten and Horsley 1995). Noticeably absent from South Kingstown's groundwater ordinance is any regulation of farming operations.

Many factors will contribute to the content of a groundwater zoning district. Included among these might be historical attitudes toward natural resource protection, the political situation, influential interests at the time of passage, prior contamination of water supplies and State enabling legislation (Jeer 1995a). Article 20 comprehensively regulates industrial and commercial uses located over recharge areas, a result of the historical importance of groundwater protection among local residents. Specifically, consensus over the need to protect drinking water supplies resulted in cooperation among business owners, politicians, and developers in the adoption of GPOD legislation. The obvious omission of agricultural uses from GPOD can be directly attributed to the historical importance of farming in town, influential political groups at the time of GPOD adoption, and then-recent changes occurring in the town. Concern over a loss of farming operations resulting from over-regulation led to the virtual elimination of provisions 
regulating farming operations. Local farmers, scientists at URI, and officials at the state level allied to ensure that the groundwater legislation would not negatively affect the town's viable working farms.

Recent changes in development patterns in South Kingstown have given farmers and local officials a lot to worry about in relation to farming. Between 1970 and 1990 the town's population increased significantly, growing by more than 20 percent in both decades, with record numbers of building permits issued several subsequent years. During GPOD adoption, the Town weighed the necessity of protecting continued viable farming operations against preservation of groundwater quality. As shall be discussed, the Town chose to risk potential contamination of water supplies from farming operations rather than jeopardize the loss of local farms and open space.

The overlay district is crucial to the Town's agenda for groundwater protection, yet is only one component of a series of Town efforts. Similar measures that function in a regulatory manner and non-regulatory techniques have been part of the town's overall agenda for groundwater protection for many years. Preparation of the Wellhead Protection Plan for submission to DEM has provided an opportunity for the Town to assess strategies to date, and address discrepancies between need and protection efforts.

This research project will answer questions specific to the content of GPOD, it will assess how GPOD fits into the Town's overall strategy for groundwater protection, and the ways in which passage of the Wellhead Protection Plan will complement existing efforts. Additionally, the project is designed to serve as guidance for officials in adjacent communities, all part of the 194,000 acre Pawcatuck Watershed, as they develop their own agendas for wellhead protection. This will enable neighboring communities to 
benefit from the experience of South Kingstown. It is intended to encourage regional cooperation for joint protection of nonrenewable resources.

The project is a by-product of time and effort spent developing the South Kingstown Wellhead Protection Plan. Combining the requirements of a graduate research project with the responsibility of plan preparation as an intern with the South Kingstown Planning Department has resulted in two separate documents serving distinct purposes.

\section{Chapter Outline}

The outline of the document is as follows. Chapter Two will introduce the reader to federal, state, and local responsibilities under the Safe Drinking Water Act. The Federal discussion consists of a review of laws for water protection and an assessment of their effectiveness. An explanation of the specific steps outlined in the Rhode Island Wellhead Protection Program follows. The relationship between wellhead protection and existing laws, and the shortcomings of State regulations to date is also included. The third component of chapter two will identify South Kingstown's role in wellhead protection. The Town's existing strategies are detailed.

Chapter Three briefly outlines the elements of South Kingstown's Wellhead Protection Plan as shall be submitted to DEM for review. Exacting details of the plan will not be included, rather the general purpose of each section will be explained. The full plan is included as Appendix A.

The fourth chapter will discuss in detail South Kingstown's Groundwater Protection Overlay District. The GPOD legislation restricts uses and activities in three regions of town. This chapter will critique the ordinance based on two criteria: 
1. "Expert" judgment as to what a comprehensive aquifer overlay should encompass, and

2. The uses and activities that occur in those areas regulated by the ordinance.

The relationship between the three central factors collectively influencing GPOD content will also be considered: the historical importance of farming, active individuals capable of affecting GPOD content, and unprecedented growth in South Kingstown in the 1980s.

Chapter Five will detail the effectiveness of South Kingstown's groundwater efforts through an assessment of water quality data provided by the Department of Health. The second section outlines recommendations for neighboring communities based on the experience in South Kingstown.

The final chapter is a concluding discussion of groundwater protection in general terms. What is there to learn from the strengths and weaknesses of existing legislation and programs? Ideally, what path will groundwater protection strategies follow in the future? Elements critical to the long-term protection of water supplies will be discussed. 


\section{II: Literature Review: Wellhead Protection in Context Federal Requirements for Wellhead Programs}

Section 1428 of the 1986 Amendments to the Safe Drinking Water Act (32 U.S.C. 300 f et seq.), initially passed in 1974 , contains the following mandate for every state nationwide.

"The Governor or Governor's designee of each State shall, within 3 years of the date of enactment of the Safe Drinking Water Act Amendments of 1986, adopt and submit to the Administrator a State program to protect wellhead areas within their jurisdiction from contaminants which may have any adverse effect on the health of persons."

With the passage of this law, Congress supplemented existing laws designed to proactively preserve the quality of the nation's drinking water supplies. Entitled "State Programs to Establish Wellhead Protection Areas," section 1428 specifies the minimum requirements of each State program. Six particular actions mandated in the legislation are:

1) Specify the duties of State agencies, local governments, and public water suppliers as each relates to wellhead protection;

2) Determine the wellhead protection area for each public supply well based on hydrogeologic data and other information;

3) Identify all anthropogenic sources of contaminants that have any potential of causing adverse effects on people's health; 
4) Create a program to protect the water supply within wellhead protection areas that contains appropriate technical and financial assistance, control measures, education, training, and demonstration projects;

5) For each public water system include contingency plans for water supplies in the event of well or wellfield contamination; and

6) Consider the potential sources of pollution within any future wellhead area for a public supply system.

Although not specified in the above mandate, a final requirement of any wellhead program is that states encourage public participation in program development.

\section{Criticisms of the Federal Mandate}

The amendments to the Safe Drinking Water Act have been criticized as being just another unfunded mandate and "an embodiment of the federal command-and-control, one-size fits-nobody approach to environmental protection" (Adler 1996). Yet this is one of few federal laws that sets an arena for active protection of groundwater reserves (Gardella and Ribb 1991, Spizuoco 1993). In this legislation, the Federal government set the standards, outlined minimal requirements, and ordered the states and municipalities of America to actively protect water supplies. Unfunded as it may be, delegation of this program to states and towns is reasonable: Each component of the program must be, and through local efforts can be, suited to the individual needs of a community. The political realities, potential for contamination, and possibilities for protecting water supplies in South Kingstown, Rhode Island, for example, will require a unique program for wellhead protection, one which may differ in form or content from all other communities in the

United States. A cookie-cutter approach to water protection for every American 
municipality will not work. Thus, the devolution of this legislation, much in accordance with recent trends at the federal level (Goetz 1993), can serve its function if applied both critically and appropriately by towns. The federal government is incapable of prescribing exact procedures for groundwater protection that South Kingstown needs to follow.

\section{Federal Laws to Protect Groundwater}

As unique as the requirements may be with regard to water resources, the law is consistent with other Congressional legislation. From the early days of environmental regulation with passage of the National Environmental Policy Act of 1969, to many that have proceeded it, the United States Congress has demonstrated consistent concern, at least in word, with the quality of the nation's water supplies.

\section{The Principal Laws}

In response to growing concern with the state of the nation's water bodies and supplies, dramatized by the 1971 Water Wasteland, a Ralph Nader Task Force Report (Adler, Landman, and Cameron 1993, 5), Congress enacted the Federal Water Pollution Control Act, better known as The Clean Water Act, in 1972 (33 U.S.C. 1251 et seq.; 40 C.F.R. 104). Amended in 1977, 1987, and 1990, the stated purpose of the law is to "restore and maintain the chemical, physical, and biological integrity of the Nation's waters."

The law has failed to meet the initial goals of 1972 in many ways (Beatley 1992), but it has resulted in some positive elements, including several programs relevant to groundwater protection. The National Pollution Discharge Elimination System (NPDES; 40 C.F.R. 122), a component of the 1990 amendments, is a permitting procedure to control industrial pollution discharge into public waterways. Permits for discharge are issued on the condition that any effluent will meet statutory standards. Federal law encourages states 
to adopt their own permitting programs, provided that standards are as strict as CWA requirements. In response, Rhode Island adopted the Rhode Island Pollution Discharge Elimination (RIPDES) system in 1993.

A facet of the Clean Water Act that more specifically applies to drinking water protection is Section 319, the Nonpoint Source Management Program. The Federal government requires states to prepare a report identifying significant sources of nonpoint pollution for a given body of water. The report must also state the likelihood of compliance with federal guidelines based on nonpoint source pollution. Each state must obtain EPA approval of a management program designed to address and control nonpoint sources as well as best management practices to reduce pollution.

Finally, publicly owned treatment works (POTWs) were targeted under the Clean Water Act and enabled the EPA to disburse funds for the construction of public sewage plants. With funding allowances, the agency is entitled to determine the suitability of a designated area for a POTW and to set effluent limitations.

In addition to establishing the Wellhead Protection Program, the 1986 amendments to Safe Drinking Water Act (SDWA) contain several critical components. The legislation establishes maximum contaminant levels (MCLs) for pollutants commonly found in water supplies. Each MCL is set at a level known to produce no adverse health effects. Prior to the amendments in 1986, 22 of 700 known contaminants were regulated in this manner. The amendments added an additional 61 contaminants to the regulated list. This provision applies only to public water suppliers. There is no monitoring mechanism for residences drawing from private wells. 
The SDWA provides specific provisions to protect sole source aquifers (SSAs), serving as the only viable source of water in an area. The Pawcatuck Watershed, the source of drinking water for all of southern Rhode Island, was designated an SSA in 1991.

The Clean Water Act and Safe Drinking Water Act comprise the federal legislation that specifically targets ground and surface water supplies. Although supplemented by a series of laws that assist in the protection of water supplies, as shall be discussed, these two laws provide the framework for protection.

This thus raises the question of how the laws have performed in time. Are our water supplies that much safer and cleaner as a result of the legislation? This is a difficult question to answer with any degree of confidence (Freeman 1993, 110).

Using the Clean Water Act as a basis of assessment, several authors acknowledge that there has been some improvement in water quality since 1972 (Adler, Landman, and Cameron 1993, Freeman 1993). Yet these changes have not been dramatic. Findings by both sets of authors simultaneously report that some water bodies indicate declining quality (Freeman 1993) and violations of EPA's contaminant levels. This leads to the logical conclusion that many U.S. waters are "no more drinkable than they are swimmable, even after expensive treatment" (Adler, Landman, and Cameron 1993, 42).

The Safe Drinking Water Act has been criticized for falling short of providing safe water supplies (U.S. Congress 1991, Waxman 1994). The failures have been demonstrated through several recent disasters in public water supplies, most notably the Milwaukee contamination in March 1993 that left 800,000 residents without potable tapwater for a week and led to the deaths of 40 residents (Waxman 1994). Similar incidents have occurred in New York, Washington D.C., Las Vegas, and small towns across the country (Waxman 
1994, Sierra Club 1996). Such disasters can be traced to lax water treatment and weak pollution controls (Sierra Club 1996).

In a 1991 hearing before the subcommittee on Superfund, Ocean, and Water Protection of the Senate Committee on Environment and Public Works, testimonies from several speakers indicate that the effectiveness of the SDWA has been discouraging. Senator Lautenberg (New Jersey) reported that the increased public health protection promised in 1986 was not being met, and that serious shortcomings in compliance and enforcement had been documented (U.S. Congress 1991, 2). An additional criticism was that it would take many decades for communities to receive protection from contamination in their water supplies (U.S. Congress 1991, 19, 49). Important to note is that most criticisms of the failure to provide potable water are not aimed at the content of the SDWA, but rather at problems associated with implementation of the mandates. Stated Erik Olson, Counsel for the National Wildlife Federation, at the hearings, "[N]one of the drinking water program's failures are necessitated by any fundamental flaw in the Act itself. Rather, the public health threats posed under the program generally are the result of poor EPA and State drinking water program implementation, and by the lack of resources provided to those programs" (U.S. Congress 1991, 50).

\section{Additional Federal Regulations}

The CWA and SDWA are not the only laws that address water supplies. A number of environmental acts assist in the protection of water secondarily. Included among these are the Resource Conservation and Recovery Act (42 U.S.C. 6901), the Comprehensive Environmental Response, Compensation, and Liability Act (or "Superfund," 42 U.S.C. 9601; 40 C.F.R. 300), the Toxic Substances Control Act (15 U.S.C. 2601; 40 C.F.R. 700), 
the Federal Insecticide, Fungicide, and Rodenticide Act (7 U.S.C. 136h; 40 C.F.R. 152) and the National Environmental Policy Act of 1969 (42 U.S.C. 4231; 40 C.F.R. 1500), among others.

The stated purpose of each is to protect the health, safety, and welfare of the American public, and to protect the environment. The ways that the laws are supposed to accomplish this is through, for example, mandating the remediation of hazardous waste sites, regulating the transport of toxic materials, creating standards for the use of pesticides in agriculture, and requiring impact assessments for federal actions and federally funded projects.

There has been no thorough assessment of how the additional laws have assisted in the protection of water supplies. Based on the review of Clean Water Act and Safe Drinking Water Act, it is quite safe to conclude that these additional laws have not necessarily improved the quality of the nation's waters, although it is also possible that the waters would be in worse conditions if these laws were not in place. Enactment of each has probably prevented further degradation of water supplies by establishing guidelines to be met in the regulation of potentially hazardous activities.

Although these federal laws provide a long list of regulatory precedents by Congress, in total they still fail to develop an agenda that comprehensively coordinates the protection of water supplies. Some elements overlap, some conflict with each other, and elements central to long-term provision of drinking water are omitted from the agenda (Gardella and Ribb 1991; Spizuoco 1993). 


\section{State Level Efforts for Drinking Water Protection}

In response to and in accordance with the Safe Drinking Water Act amendments, the Rhode Island General Assembly amended the Rhode Island Groundwater Protection Act of 1985 to include provisions for the wellhead protection program. The Rhode Island Department of Environmental Management (DEM) was charged with overseeing program development for the entire state, and to monitor municipal compliance with the law. More specifically, the Groundwater Section of DEM Division of Groundwater and Individual Sewage Disposal Systems (ISDS) has lead responsibility in the state.

\section{The Rhode Island Wellhead Protection Program}

The Rhode Island Wellhead Protection Program (WHPP) consists of seven elements, each as specified by the Safe Drinking Water Act. Element seven coincides with the SDWA Section 1428(b) encouraging public participation in the plan development process.

DEM outlined the criteria for each of the elements of the program in its 1990 publication entitled the Rhode Island Wellhead Protection Program. Highlights of each component as described by DEM are as follows:

Roles and Responsibilities of State and local officials and water suppliers

Responsibilities of key players at every level include:

Federal Government -- Regulatory power to control and clean up sources of groundwater contamination (Rhode Island Department of Environmental Management 1990,6).

State Government -- Similar regulatory power as the federal government in controlling and cleaning up sources of pollution. In the WHPP, the State role is primarily to provide necessary tools to local governments to successfully implement a wellhead protection 
program. State agencies identified by DEM as crucial to successful plan development are the Rhode Island Department of Health (DOH) and the Rhode Island Water Resources Board (WRB) (Rhode Island Department of Environmental Management 1990, 6-7).

Local Government -- Local governments have the responsibility of establishing land use controls to protect groundwater recharge areas that supply local wells. The efforts of local governments must supplement those of the local suppliers (Rhode Island Department of Environmental Management 1990, 11).

Water Suppliers -- The large water suppliers in the State must submit water quality protection plans to the WRB. Necessary components are inventory of potential sources of pollution, contingency planning, and management approaches to groundwater protection. As discussed by DEM, it is the responsibility of water suppliers to ensure that water is drinkable, or potable, for customers. Authority of doing so is generally limited to the small area of contribution within the actual wellfield area (Rhode Island Department of Environmental Management 1990, 10).

In an outline of requirements for the various levels of authority in wellhead protection, DEM included a matrix of tasks with 33 specific steps. DEM identified the wellhead protection effort in Rhode Island as "shared" between the State and local levels (Rhode Island Department of Environmental Management 1990, 6). Of the 33 tasks, 29 of the tasks are delegated to State agencies, including DEM (27 tasks), DOH (3 tasks), WRB (1 task), and the Department of Administration, Division of Planning (1 task). The remaining four tasks are assigned to municipalities and water suppliers. Quantification of these qualitative tasks is impossible, yet the sheer number of required steps within the wellhead protection program make it clear that DEM assumed much of the responsibility. 


\section{Wellhead Protection Area Delineation}

With the assistance of Federal, State, and local organizations, DEM developed and adopted methods for initial wellhead protection area delineation in the State. DEM conducted delineations for all public supply wells in a matter of months with the expectation that refined delineations would be completed in the future. This enabled DEM to identify critical areas for all public supply wells state-wide, thus providing the basis for municipal plan development.

Delineation of wellhead protection areas for recharge areas required several steps and was based on hydrogeologic settings of the major groundwater aquifers in the town. Wells were divided into three classes based on geologic formation (stratified drift or bedrock), population served (community or non-community service area), and maximum yield (less than or more than 10 gallons per minute, gpm) (Rhode Island Department of Environmental Management 1990, 17). These three factors assisted DEM in determining an appropriate numerical modeling process to identify the critical portion of water draw. For the large community wells, hydrogeologic mapping coupled with analytical modeling produced wellhead protection areas of unique size and shape, such as the WHPAs of the South Shore system and the United Water wells in South Kingstown (Rhode Island Department of Environmental Management 1990, 18). A calculated fixed radius was determined appropriate for the small, non-community well systems with yields less than 10 gpm. The radii for all such wells statewide is 1750 feet, forming a circular wellhead protection area. Map 2 in Appendix A identifies the wells and delineated areas in South Kingstown. 
The delineations define the critical areas recharging public water supply wells, and serve as the boundaries of the wellhead protection areas (WHPAs). These are the areas that serve as focal points for inventories of potential contaminants and of land use management strategies.

According to DEM materials, refined delineations are to be completed for all wellhead protection areas. At the time of this writing, few state or local efforts have thus far been directed toward refinement of wellhead areas (Panciera 1997). Staffing and monetary limitations exist at both state and local levels.

\section{Contaminant Source Identification}

Identification of potential sources of pollution began only after WHPA delineation. Responsibility for the inventory rests with each municipality and the water suppliers. To assist in the inventory process, DEM prepared a list of potential contaminants based on national and local sources. DEM also assigned each type of activity to a level of risk: High, moderate, and low. The State expects that suppliers and towns will both list and map identified risks and their general location. DEM set requirements that high risk sites be mapped on maps at a scale of $1: 24,000$ and that lower level risks be appropriately mapped to identify the site of every septic system, every underground storage tank, every agricultural field, and so on (Rhode Island Department of Environmental Management 1990, 23).

DEM also specified that towns must update their inventories every five years, and that departments within a municipality share the tasks of listing and updating (Rhode Island Department of Environmental Management 1990, 24). For example, this would encourage communication between the South Kingstown Planning Department, 
responsible for inventorying, and the Building Official, responsible for granting permits for new construction and changes of use in groundwater protection areas.

\section{Management Approaches}

According to DEM's description of the Wellhead Protection Program, expected management approaches are to surpass traditional approaches to groundwater protection, both regulatory and non-regulatory, through inclusion of technical and financial assistance, education, and project demonstration. The descriptive materials state outright that the wellhead program promotes no new source regulations at the state-level contamination (Rhode Island Department of Environmental Management 1990, 26) . All management strategies are expected at the local level.

A second element central to the Wellhead Protection Program is advocacy of local best management practices (BMPs) for nonpoint sources of pollution. Regulations do not control sources such as salt storage facilities, road deicing, and many agricultural activities. It is the responsibility of local governments to engage in educational efforts to address such sources of groundwater contamination (Rhode Island Department of Environmental Management 1990, 26).

Submission of wellhead protection management plans is the responsibility of both local governments and of large water suppliers. DEM advocates communities to institute management practices that will most benefit the residents of a community and the local suppliers (Rhode Island Department of Environmental Management 1990, 27). According to DEM, wellhead protection planning should be implemented as part of the local planning program. 
Management plans as submitted to DEM must include five components:

1. Past community efforts to protect groundwater supplies

2. Assessment of groundwater quality within WHPA

3. Identification of those management approaches most appropriate to groundwater protection in a given community

4. Implementation strategies

5. Five year plan of activities (Rhode Island Department of Environmental Management 1990, 28).

\section{Contingency Planning}

The mandate for contingency planning supplements existing State and Federal laws that require water suppliers to prepare for emergencies. As stated in the description document, most large suppliers in the state have begun addressing water emergency planning to some extent. Contingency planning as part of the Wellhead Protection Program will provide an opportunity for state and local water suppliers to revisit existing plans and procedures to ensure comprehensiveness. Three suppliers in South Kingstown serving more than 10,000 people are required to submit plans. DEM also encourages non-community suppliers to prepare contingency plans, although this is not a State mandate.

Management of Pollution Sources in WHPAs of New Public Wells

In 1990 the Rhode Island Water Resources Board had identified new, potentially high-yielding, well sites around the state. DEM has the responsibility to delineate new WHPAs and respective localities will be responsible for incorporating future sites in the municipal plan.

The Department of Health approves new wells but has historically provided no specific requirements for new source approval (Rhode Island Department of 
Environmental Management 1990, 35). Incorporation of new wells in a wellhead program could significantly enhance the potability of future water supplies.

\section{State Laws for Groundwater Protection}

As at the Federal level, DEM's Wellhead Protection Program supplements existing State legislation designed to protect groundwater resources. These programs are primarily administered through divisions within the Department of Environmental Management and supplemented by Department of Health. The General Assembly has passed a significant number of laws that address groundwater protection in various ways. Primary among these are the Rhode Island Water Pollution Act (RIGL 46-12), the Rhode Island Groundwater Protection Act of 1985 (RIGL 46-13.1), and the Public Drinking Water Protection Act of 1987 (RIGL 46-15.3)

The Rhode Island Water Pollution Act provides broadly for the protection of Rhode Island's surface and groundwaters. Specific provisions of the act, which complies with the Clean Water Act and the Safe Drinking Water Act, include program development to prevent water pollution, permit issuance for pollution discharge (RIPDES), septic treatment oversight to ensure compliance with Federal pretreatment regulations, and establishment of water quality standards.

The law addresses location of wells in proximity to solid waste disposal areas, inground and surface disposal of industrial and commercial pollutants, establishes the UST replacement revolving loan fund administered by DEM, and provides guidelines for testers of underground storage tanks.

The Rhode Island Groundwater Protection Act established the mandate for groundwater classification based on water quality and required a DEM assessment of all 
groundwater reserves. The General Assembly mandated calculations of projected use and recommendations for appropriate land uses, regional planning, and future engineering projects. The Act was amended in 1988 to include provisions for wellhead protection.

The Public Drinking Water Protection Act provides funding for water suppliers statewide to further supplier-initiated protection efforts. Funds are provided via a surcharge of several cents for every 100 gallons of water sold to retail and wholesale users of public water. The Rhode Island Water Resources Board, developed via this law, is responsible for administering the funds. The law specifies that no less than 55 percent of funds may be used for land purchases, a maximum of 10 percent may cover administrative expenses, and the remaining 35 percent of funds can be employed in other protection projects.

\section{Effectiveness}

According to a 1991 assessment of Rhode Island State regulations for drinking water, twenty-five laws and policies apply to water resource protection (Spizuoco 1993, 5658). As at the federal level, some of the identified laws apply secondarily to water protection. For example, tracking of hazardous materials and issuance of wetlands permits, while important to groundwater, are complementary but secondary to laws that focus entirely on water protection.

Spizuoco identified two shortcomings after close examination of Rhode Island statutes and programs. First, there is a lack of water quantity withdrawal monitoring. Rhode Island is the only New England state that lacks a groundwater withdrawal permit system. Any comprehensive management program must address the effects of withdrawal rates and quantities on water quality. Quantity will affect quality, for example, when large withdrawals reduce dilution of a contaminant (Spizuoco 1993, 60). 
Second, the current State approach is directed more toward protecting existing drinking water supplies than any future supply sources (Spizuoco 1993, 63). In the WHPP, DEM delineated recharge areas to existing water suppliers based on current withdrawal rates. This method is criticized because it does not project future needs or future well sites (Spizuoco 1993, 60).

The state Wellhead Protection Program encompasses the EPA requirement that future potential sources of water supply be considered in program development. In the guidance materials provided to towns for plan preparation by DEM, the State acknowledged that future well sites identified by the Rhode Island Water Resources would require incorporation into municipal wellhead plans (Rhode Island Department of Environmental Management 1990). Although test wells have helped to identify appropriate future sites, North Kingstown is the only Rhode Island community that petitioned for inclusion of any future well locations in their protection plan. Other sites identified by the WRB as appropriate locations for future wells, most of which are in South County, have not been incorporated in plan preparation by municipalities, nor has DEM actively petitioned for inclusion (Panciera 1997).

The State program for wellhead protection is a strategy that has not been experienced before in Rhode Island. Unlike the majority of programs currently administered by DEM that are regulatory in nature (e.g. registration of underground storage tanks and underground injection control, wetlands permitting), DEM is primarily providing technical support to communities. Overseeing municipalities' compliance with adopted plans will become an issue during the next several years, and it will require DEM 
to develop means of encouraging communities to innovatively prevent future contamination of water supplies.

To date, the program has allowed the individual cities and towns of Rhode Island to discover how best to meet their respective groundwater protection needs. Preparation of wellhead protection plans affords communities an opportunity to assess strategies for groundwater protection in place already. In South Kingstown, for example, this entailed analysis of federal, state and local regulations and of state and local non-regulatory programs. Discrepancies between what now exists and what should exist to ensure safe water supplies were then identifiable. South Kingstown's strategies for future efforts will reflect existing discrepancies.

\section{Education}

Central to the Rhode Island Wellhead Protection Program is the requirement that towns adopt an educational component for groundwater protection. Although the State and South Kingstown have established many laws to regulate uses and require clean-up, both have been remiss in incorporating education in those efforts. Particularly important is the education of town residents on contamination stemming from non-regulated sources. In South Kingstown this applies most specifically to on-site septic systems and residential use and disposal of toxic substances.

Comprehensive educational programs in municipalities across the state will substantially increase the likelihood that existing groundwater resources will be protected. Discussion of components applicable to South Kingstown is included in Appendix A. 


\section{Groundwater Protection in South Kingstown}

The Town of South Kingstown has historically initiated measures to protect community natural resources, including groundwater supplies. The efforts have been primarily regulatory in nature but have also consisted of non-regulatory measures. The following sections discuss some of both techniques currently in practice.

\section{Regulatory Efforts}

\section{Zoning Regulations}

The South Kingstown Town Council adopted large-lot zoning in 1976 and 1984 as a way to preserve groundwater aquifers and other natural resources. The zones consist of two-acre rural residential zones (RR80) and five-acre rural low density zones (RLD200). The predominant zoning over groundwater aquifers and recharge areas is large-lot, which decreases some of the burden on natural systems and reduces the possibility of pollution of the groundwater reserves.

Performance standards limit emissions of noxious pollutants from commercial and industrial uses. Article 13 of the zoning ordinance established limits not to be exceeded as they relate to toxic emissions, including liquid waste. The standards were established in accordance with those recommended at the state and national levels. The standards and limitations established pertain to recharge areas with several additional requirements placed on industrial users within the groundwater overlay district (see below).

Regulations pertaining to water bodies and wetlands apply to groundwater because of the interconnected nature of surface and ground waters. Section 308 of the zoning ordinance protects groundwater through the provision that no sewage disposal system, or other facility designed to leach liquid wastes into the soil, can be located within 150 feet of 
a freshwater wetland or coastal wetland. This requirement is more strict than the State regulation that provides for a minimum 50 foot setback between disposal systems and wetlands. Section 308 also requires that there be a minimum three foot separation between the bottom of the septic system and the seasonal high water table. This reduces the risk of contamination of drinking water supplies from wastes associated with on-site sewage disposal.

Development Pacing and Phasing, Article 23, was adopted in July 1996 and addresses groundwater protection through the Town goal of minimizing burdens on natural resources. During periods of rapid town growth a limit will be placed on the number of permits issued for construction of new residential dwellings. Such provisions will be in place until the Town can take remedial steps.

The Soil Erosion control measures were adopted in July 1996 as an amendment to Article 3 of the zoning ordinance. The legislation requires sediment control plans for construction of new single, duplex, or multi-family detached structures. Expansion of any existing structure of more than 1,000 feet in ground coverage also requires a sediment control plan. Additionally, new earth removal operations must submit a soil erosion and sediment control plan to the Zoning Board of Review before a permit will be issued.

\section{Groundwater Overlay Zoning}

The most comprehensive zoning tool used by the Town to preserve groundwater quality is the Groundwater Protection Overlay District (GPOD) adopted in 1991 as Article 20 of the Zoning Ordinance. By definition an overlay district is an area encompassing underlying zones and in which requirements additional to those of the underlying zone are imposed (Moskowitz 1993). In groundwater overlay districts, activities located over 
groundwater recharge or aquifer areas receive specific use and site regulations. The goal is to regulate those uses that are most harmful to groundwater supplies. Based on research conducted thus far through database searches, the Internet, and federal and state publications, overlay districts for groundwater protection have been adopted by communities nationwide. In Rhode Island, seven towns in addition to South Kingstown have overlay districts for drinking water protection.

There are three areas that have overlay districts: The northeastern area of the town encompassing the villages of Kingston, West Kingston and the regions north and west of both places, the area of water contribution to the Mink Brook aquifer in the center of town, and 1,994 acres around Factory Pond in the South Shore system. The wells that supply the four public water suppliers are located in one of the overlay areas.

Apart from ordinances serving as examples of overlay zoning from other communities, little literature exists to serve as a guide for drafting groundwater protection legislation. A Guide to Wellhead Protection (Jeer 1995a), published by the American Planning Association Planning Advisory Service, is one of the few explanatory guidance documents in publication with any discussion of overlay districts. The guide identifies common elements of many overlay district ordinances as use regulations, performance standards, and site plan requirements. These criteria are in addition to the background information necessary to zoning amendments, such as purpose, definitions, and extent of coverage (Jeer 1995a). 
According to the author, prior to drafting an overlay ordinance a community must answer the following two questions:

1) Are provisions for overlay zoning permitted under state enabling legislation?

2) Are the provisions appropriate in the groundwater protection section of the zoning ordinance? (Jeer 1995a)

In Rhode Island, the passage of zoning enabling legislation by the General Assembly in 1991 clarified localities' ability to regulate local land uses for groundwater protection. Prior to this time ambiguity existed in the legislation drafted in 1922 and numerous questions were raised regarding jurisdictional authority (Panciera 1997). Unlike zoning for historic districts, there exists no specific provision for groundwater protection; rather, the enabling legislation empowers Rhode Island communities to "establish and enforce standards and procedures for the proper protection of land, air, and water as natural resources, and to employ contemporary concepts, methods, and criteria in regulating the type, intensity, and arrangement of land uses" (RIGL 45-24-29). An additional identified purpose of local zoning is to provide for "the control, protection, and/or abatement of...groundwater" (RIGL 45-24-30.4). As a contemporary concept in zoning designed to protect groundwater reserves, overlay zoning qualifies for enforcement under the enabling legislation.

The sections of greatest importance within an overlay article include identification of the permitted and prohibited uses, performance standards, and site plan review. Uses that should be identified in an ordinance are any that are permitted, prohibited, conditional, by special exception, nonconforming, and allowed under variance provisions (Jeer 1995a). 
Performance standards in an overlay district serve as a gauge that, if violated, will trigger additional review of a proposed use (Jeer 1995a). Included in this section should be any minimum lot size or setback requirements that differ from those of the underlying zoning district. Additionally, performance standards will govern materials that are known to contain contaminating elements, and will establish standards for determining whether existing uses with proposed expansion require review (Jeer 1995a).

A final set of criteria outlined in the guidance publication is for site plan submission requirements. In this section of a groundwater article, the regulations should identify supporting materials required for submission to obtain final plan approval. Key elements that may be required of an applicant include listing of any hazardous materials that will be used on site, the location of existing wells and public water supply system as it relates to the applicant's property, and the location of any significant geologic or natural features (Jeer 1995a).

\section{Subdivision Regulations}

In addition to the zoning ordinance, subdivision regulations can be an effective regulatory device in groundwater protection (Witten and Horsley 1995). According to the South Kingstown Subdivision and Land Development Regulations, the Planning Board may require a developer to prepare an environmental impact statement (EIS) for major subdivisions being constructed in close proximity to natural systems. The definition of natural system includes groundwater resources. However, development within a delineated wellhead protection area or within the overlay district does not necessarily oblige a developer to prepare an EIS. 
In the past three years, two subdivisions have required impact assessments: Woodfield Subdivision, whose site is in close proximity to the Rose Hill Landfill, and the South County Country Club, a large development originally platted to consist of 212 detached dwellings and an 18 hole golf course on sandy, highly permeable soils. Following environmental assessment of the Woodfield site, no alterations in the original plans were required based on proximity to the landfill. Developers of the Country Club were required to prepare a new scenario for development based on economic factors, and to recognize future needs for a golf course management plan to include best management practices (Nickerson 1997).

\section{Waste Water Management District}

The Town is considering adoption of a comprehensive waste water management program that will regulate disposal of domestic wastewater in all non-sewered areas of town, including recharge areas. The program will assist in groundwater by including several key provisions:

- Development of an ISDS inspection and maintenance program

- Establishment of a Community Assistance Program to identify and administer fund for repair and/or replacement of failed systems

- Development of a GIS based mapping system with data pertaining to various waste water management functions

- Creation of a public education program to develop and disseminate information regarding pertinent waste water issues

\section{Non-Regulatory Efforts}

\section{Tax Programs}

In addition to the laws discussed above, the Town has sponsored and become involved in programs that encourage groundwater protection efforts through non-regulatory measures. These efforts have curbed unwanted uses in groundwater areas primarily through 
land conservation efforts. The Farm, Forest, and Open Space tax status is part of a State program. The intent is to maintain Rhode Island's agriculture and forest land by allowing for use value assessment. Such assessment is based on the undeveloped value of a given parcel rather than its "highest and best" use possible. To date, twenty-seven (27) lots located over the recharge areas and within the overlay district are enrolled in the program. This comprises a total of 621 acres, or 9 percent of the total land overlying the town's three groundwater aquifers.

DEM is the entity charged with administering the program at the state level, and the Town tax assessor oversees the program in South Kingstown. Once an individual applies for and receives designation in this tax status, the individual is responsible for maintaining the property or parts thereof as undeveloped for fifteen years. A penalty fee is imposed on property owners who develop the property prior to expiration of the contract. Fees are 10 percent of the property's fair market value for the initial seven years in the program, and fall by 1 percent each year until completion. Fees are not imposed if a property is subdivided and the plan filed with the Town. Rather, once a building permit is issued for any part of the property, fees will be applied.

\section{Land Preservation Strategies}

Another strategy to maintain land as undeveloped is fee simple acquisition. The Town, local water suppliers, the Nature Conservancy, and the South Kingstown Land Trust have cooperated during the past several years to remove lands overlying groundwater reserves from development through purchase of entire parcels of property.

Significant purchases in groundwater overlay areas include the December 1991 acquisition of a 24 acre parcel within the Factory Pond wellhead protection area by the 
Town and the Nature Conservancy (Town of South Kingstown Utilities 1994) and purchase of a 47 acre parcel over the Mink Brook Aquifer in May 1996 by the South Kingstown Land Trust in cooperation with United Water Rhode Island. The Mink Brook purchase agreement conveys title of the property to the South Kingstown Land Trust and a conservation easement to United Water (Collins 1996). Funding made available through the Public Drinking Water Protection Act served as the financing mechanism for both properties.

The South Kingstown Land Trust actively seeks conservation easements in town. As of November 1996, the Land Trust owned thirty-eight properties town-wide, thirteen of which lie within or border an overlay district. The total acreage of land owned by the Land Trust is more than 600 acres, 300 of which were secured through easements (Collins 1996).

Purchase of development rights (PDR) is a strategy to preserve land from development that entails buying the right to develop a parcel of property. Generally, local or state governments purchase the development rights, with the original land owner maintaining rights to other uses of the property, such as for open space or agriculture (Nelson and Duncan 1995, 49). The Rhode Island Agricultural Lands Preservation Commission, with the support of the Town and local farmers, purchased the development rights to five farms in South Kingstown in the late 1980s and early 1990s. A total of 400 acres are preserved through this means at a cost of more than one million dollars (Sutton 1997).

Conservation easements, fee simple acquisition, and purchase of development rights are advocated measures to protect rural land that can be used in conjunction with traditional zoning measures (Nelson and Duncan 1995). A similar program that the Town 
has not implemented but identifies as a possible option for future growth management is transfer of development rights (Comprehensive Plan Policy 2.7, 77). A transfer of development rights (TDR) program typically permits land owners in "sending districts," areas where development is restricted, to sever and sell the development rights attached to their property to owners of land in "receiving districts" (Nelson and Duncan 1995, 48). A TDR program could effectively protect groundwater recharge areas in town by prohibiting development over all, or portions, of the wellhead and groundwater overlay areas through the establishment of sending districts within such regions of town. Logical locations for receiving districts are the more densely developed villages of Wakefield, Kingston, and Peace Dale.

\section{Education}

Notwithstanding limited efforts involving conservation easements and land acquisition, the Town efforts described above focus primarily on the regulation of uses in and around groundwater supplies. DEM's Wellhead Protection Program requires each municipality to assess requirements for wellhead protection given the community's unique set of circumstances. The DEM guidance document for plan preparation does not mandate that certain strategies be implemented. "However, groundwater education is one approach that must be a major component of any plan" (Rhode Island Department of Environmental Management 1996, 14).

This is an area where the Town of South Kingstown appears to have fallen quite short. According to planning department records, the Town has never actively engaged in educational strategies to build community awareness about groundwater issues. Public 
hearings, which serve as an educational tool, are required for changes to zoning. Yet this requirement serves an educational purpose only secondarily.

Although the Town's draft Water Quality Protection Plan, developed in 1990, identifies public education as a priority, the plan was never officially adopted. The Town has exhibited a lack of initiative in education. Several other entities in town have engaged in public outreach. They include the public water suppliers and Cooperative Extension at the University of Rhode Island. Through workshops and dissemination of educational materials, these local organizations have helped inform residents identify of measures to reduce water consumption better protect groundwater supplies. Meeting the educational requirement of DEM's Wellhead Protection Program mandate should not be difficult for the Town because of this established precedent. 


\section{III: Summary of the South Kingstown Wellhead Protection Plan Introduction}

The South Kingstown Wellhead Protection Plan was prepared in accordance with requirements established by the Rhode Island Department of Environmental Management Wellhead Protection Program. The State mandate for plan preparation meets the fourth phase of the program outline. Primary components as outlined by DEM include:

- Wellhead Protection Area Delineation: DEM determined the areas around public wells in the community that require special protection. These are the critical areas of groundwater contribution to the wells.

- Inventory of Pollution Sources: In accordance with State requirements, each municipality in Rhode Island inventoried potential sources of pollution to the wells and submitted a report with possible sources identified.

- Contingency Plan Preparation: All major water suppliers in Rhode Island prepared plans identifying steps to be followed in the event that a contamination of a well or groundwater source should occur.

- Wellhead Protection Plan: Completion of the plan, included as Appendix A, coupled with implementation measures, meet the final requirement of DEM. All municipalities servicing public sources through well sources must prepare a Wellhead Protection Plan.

\section{Water Resources}

Groundwater supplies in South Kingstown provide town residents with 100 percent of their drinking water and also supply a significant portion of water to Narragansett residents. Potability of the supplies is of vital importance for all individuals. Nine wellhead protection areas in South Kingstown depend on groundwater from two 
aquifers for their water supplies and additional supplies are obtained from the Factory Pond recharge area. The aquifers serving the majority of town residents, the Chipuxet and the Mink Brook, are two of the aquifers that are part of the interconnected Pawcatuck Watershed. This 194,000-acre basin overlies a total of fourteen communities in Connecticut and Rhode Island, replenishes ten groundwater aquifers, and is the source of many rivers, lakes, streams, and wetlands. The Environmental Protection Agency classified the aquifers of the Pawcatuck as Sole Source Aquifers (SSAs), because more than 50 percent of local populations depend upon these sources of drinking water supplies and because no reasonable alternative exists. The watershed's aquifers that lie in Rhode Island were ranked in the highest category for quality by DEM in 1992. This GAA designation indicates that the water supplies are suitable for public drinking use without treatment by suppliers.

\section{Public Water Suppliers}

Seventeen different users drawing water from groundwater sources in South Kingstown are classified as public water suppliers. Each falls into one of categories: Community water suppliers, non-transient non-community suppliers, and transient noncommunity suppliers. Community systems service at least 25 of the same individuals year-round. Non-transient non-community systems serve at least 25 people during six months of the year, and transient non-community systems serve at least 25 people at least 60 days a year.

The Wellhead Protection Plan is required to include strategies designed to specifically protect waters of the community suppliers. Plan elements address potential 
contamination sources of groundwater and strategies designed to address sources affecting both community and non-community water suppliers in town.

\section{Threats to Groundwater Quality}

Preparation of the Wellhead Protection Plan was completed during 1996 and 1997 by the South Kingstown Planning Department. After identifying potential sources of contamination in wellhead protection areas through windshield surveys, analysis of current and historical Town records, discussions with the local water suppliers, and review of State records for regulated sources such as underground storage tanks, the Town was able to assess threats to each wellhead area. The actual inventory of potential sources of the contamination is included as an appendix to the plan.

\section{Nonpoint Source Pollution}

The majority of sources posing a significant threat to groundwater quality are nonpoint sources of pollution. Unlike point sources that emanate from one particular source, contamination labeled as nonpoint pollution originates from no identifiable source. Nonpoint sources in South Kingstown include agricultural production, septic systems, underground storage tanks, and road runoff. Nonpoint sources are of serious concern because their origins are widespread and source identification is often difficult to define. Moreover, responding to such causes of pollution is also complex because the problem stem from practices inherent to their existence, such as fertilization of corn.

Based on the assessment of these sources, the Town was able to identify relative risk to wells from groundwater contamination. No single well is seriously threatened. Rather, in the Kingston and West Kingston areas of town, ten wells are located within six wellhead protection areas and all draw from the Chipuxet aquifer. Threats to these wells 
is higher than any where else in town because of activities in the West Kingston Industrial Area, septic systems, agricultural production, runoff from Route 108, and two hazardous waste sites nationally ranked through CERCLA.

\section{Existing Strategies for Groundwater Protection}

To ascertain how to best protect water supplies in the future, it is necessary to evaluate efforts currently underway. A central element of the plan is a discussion of the legislation, programs, and strategies in place and thus far employed to address issues of groundwater quality. Efforts to protect water supplies exist at several governmental levels and a review of each was undertaken to assess existing laws and programs.

At the federal level, this entailed research of existing Congressional acts and ensuing federal programs. No single Federal law comprehensively addresses groundwater protection. Rather, components of a number of federal legislative acts serve to protect water supplies. Some laws are remediative, such as CERCLA which mandates clean-up of hazardous waste sites to prevent further contamination of water supplies. The Safe Drinking Water Act of 1986, the National Environmental Policy Act, and components of the Federal Insecticide, Fungicide, and Rodenticide Act are preventive. Actions are required of specific parties to guard against future contamination of water supplies. Federal legislation regulates the actions of individual actors in the United States, or serves as a mandate for States to develop a program to address water quality. Such is the case for the SDWA and wellhead protection.

To assess Rhode Island State programs for groundwater protection, contact was made with the Departments of Health and Environmental Management and the appropriate divisions therein. Discussions with State staff as well as review of program 
literature and State law were necessary steps to appraise the variety of ways in which State departments become involved in groundwater protection.

Many of the State programs designed to address water issues were mandated by passage of legislation in the General Assembly. The Rhode Island Water Pollution Act, the Groundwater Protection Act and the Public Drinking Water Protection Act culminated in programs that comprehensively serve for groundwater protection. The State also regulates underground storage tanks, underground injection control units, and the application of pesticides by professional farmers. Although such laws do not eliminate the threat of pollution to groundwater, they do help to control such threats and have most likely served to minimize pollution from particular sources.

Locally, discussions with officials within various Town departments, examination of the Town Code of Ordinances, the Zoning Ordinance, and the Land Development and Subdivision Regulations shed light on some regulatory and non-regulatory measures set in place by South Kingstown. Discussions with members of various Town commissions and boards allowed further insight.

South Kingstown has effectively regulated uses that could pose threats to water quality primarily through the zoning. Large-lot zoning of 80,000 and 200,000 square feet in strategic areas of town and the Groundwater Protection Overlay District (GPOD) provide examples of Town legislation serving to protect water quality. GPOD limits permitted uses in all aquifer recharges areas and in which the majority of public supply wells are located.

Non-regulatory efforts at water protection have consisted primarily of land conservation and acquisition techniques. In cooperation with the South Kingstown Land 
Trust, the Town has secured easements and acquired parcels of land overlying recharge areas. Additional non-regulatory programs are the Farm, Forest, Open Space program and emergency response planning.

Finally, all of the community and non-community water suppliers were contacted to discuss efforts for water quality preservation. For the large, community suppliers which include Kingston Water District, United Water Rhode Island, University of Rhode Island, and South Kingstown Utilities Department, meetings with staff were supplemented by review of each supplier's water management plan. Site visits and discussions with representatives comprised the preponderance of research into noncommunity suppliers' efforts.

Contingency planning is a strategy mandated by the State and employed by each of the suppliers. More proactive efforts incorporating land acquisition and educational efforts are also employed by the three of the suppliers. South Kingstown Utilities Department and United Water both recently purchased considerable tracts of land in proximity to their wells. Kingston Water District identifies properties for acquisition as part of the water management plan.

\section{Recommendations}

Recommendations were developed after careful assessment of threats to water quality and current protection strategies. Resulting recommendations reflect the need to fill identifiable gaps between threats and existing mitigative and preventive approaches. Although not all risks of contamination can be eliminated, more proactive efforts can be adopted to further minimize hazards to water quality. The recommendations fall into three distinct categories: education, legislation, and cooperation. 


\section{Education}

South Kingstown has done a commendable job of supplementing Federal and State regulations. Thus, new legislation is not a priority recommendation. The area of groundwater protection that does require concerted Town effort is education of local residents on groundwater issues. Homeowners are a primary target because of the adverse environmental impacts associated with septic systems and indiscriminate application of lawn fertilizers. Additional recommendations for homeowner education address the need to capitalize on existing resources available through the University of Rhode Island and to find new sources of funding. Businesses located within wellhead protection areas and professional farmers also need to be part of an educational strategy. Both groups may be unaware of the resources underlying their sites or of techniques that can be employed to reduce groundwater contamination. Finally, local residents and visitors to the area can benefit from signs that inform of wellhead protection area boundaries.

\section{Legislation}

The first recommendation that will require legislative changes for new additional legislation encourage adoption of a Waste Water Management District (WWMD) in sensitive regions of town. The program would mandate ISDS inspections and could provide educational and financial assistance to homeowners living within the district boundaries.

A second recommendation encourages Town investigation of a nutrient loading ordinance. This will require developers to assess the ability of local groundwater reserves to withstand additional nutrient loadings resulting from new development. 
Two additional recommendations cite the need for timely evaluations of and revisions to existing regulatory and non-regulatory approaches. Also encouraged is consideration of a transfer of development rights (TDR) program. Finally, the Town should examine the feasibility of mandatory alternative septic systems in wellhead protection areas.

\section{Cooperation}

The nature of groundwater in South Kingstown and the entire southeastern portion of the State mandates cooperation between towns. The Pawcatuck Watershed encompasses a total of fourteen municipalities in Connecticut and Rhode Island. Pollution of groundwater follows no political boundaries, so joint efforts for groundwater protection are necessary among all fourteen communities. Several non-profit organizations have formed to assist in developing protection efforts among the various communities. The Wood-Pawcatuck Watershed Association and the Pawcatuck Watershed Partnership are two groups that can aid the Town of South Kingstown in developing policies that are compatible with and complimentary to programs in neighboring municipalities. The Town must also address cooperation within the town boundaries. Community and non-community water suppliers alike need to dialogue with the Town to determine joint strategies for future groundwater protection.

\section{Implementation}

The implementation component of the Plan must cover a five year period. During the first two years of the program it is recommended that the Town focus on educational strategies and regional cooperation. Adoption of the WWMD district is advocated 1998

because the Town will hire a consultant to prepare a feasibility study in 1997. 
Examination of existing legislation is encouraged after year two of the Wellhead Program.

Any strategy for groundwater protection will require continual reassessment and evaluation. The five year framework sets guidance for initial efforts, but also recognizes that all efforts, particularly educational strategies, must be on-going. 


\section{IV: Local Implementation of Groundwater Protection}

\section{South Kingstown's Groundwater Protection Overlay District}

Article 20 of the Town of South Kingstown's Zoning Ordinance is the Groundwater Protection Overlay District legislation. The article is divided into the following sections:

Section 2010 Establishment of District

Section 2011 Purpose

Section 2012 Delineation of Districts

Section 2013 References

Section 2020 Permitted Uses

Section 2021 Prohibited Uses and Activities

Section 2030 Site Design Standards

Section 2031 Maintenance of Facilities

The sections of greatest importance in this analysis are Permitted Uses, Prohibited Uses, and Site Design Standards. The other sections serve as background and provide residents with information necessary to understand how the article was developed and provisions for enforcement. Although essential to any groundwater overlay legislation, they do not merit attention in this study.

\section{Permitted Uses}

At the time of passage, GPOD boundaries included 1,681 lots with an acreage accounting for 22 percent of the town's total land area, a significant portion of the total acreage.

Uses permitted in the GPOD are those that can legally exist in the underlying zoning district by right or through special use permit, as outlined in Section 220 "Schedule of District Regulations." 
The official zoning map in use in 1997 indicates the following uses are allowed in the zones underlying GPOD:

M1 industrial and manufacturing uses

RLD 200 five acre single-family residential

RR 80 two acre single-family residential

$\mathrm{R} 40$ one acre single-family residential

$\mathrm{R} 40 \mathrm{~A}$ one acre single-family residential, residential tourist facilities, and selected public facilities

R 30 three-quarter acre single-family residential

$\mathrm{R} 20$ one-half acre single-family residential

C 2 neighborhood retail

C 3 neighborhood retail and multi-household residential development

The only manufacturing district located within a GPOD area is the West Kingston Industrial Park, in the western region of town. As will become evident in the following discussion of prohibited uses, industrial manufacturers are fairly well regulated in West Kingston. Most of the land area is zoned for residential development, except three small tracts in Kingston zoned for commercial development.

\section{Non-Conforming Uses}

Although the article does not discuss pre-existing and non-conforming uses in the GPOD boundaries, any use located within the GPOD designated areas prior to 1991 was permitted to continue as a non-conforming use in accordance with Article 4 of the zoning ordinance, "Non-conforming Uses."

By law, legally existing, non-conforming uses are permitted to continue but must adhere to several restrictions. Except by special permit, a non-conforming use may not be expanded, moved, or resumed after abandonment. No non-conforming use may be changed to another non-conforming use and rebuilding of any structure housing a non- 
conforming use after accidental damage or destruction must commence within one year of the damage.

Several of the uses existing in GPODs are legally non-conforming uses. Included among these are a gasoline service station and school bus storage. Provided that owners meet the requirements outlined above, non-conforming uses may continue.

\section{Prohibited Uses}

There are twenty-three uses prohibited from the GPOD that are normally permitted in underlying zoning. Examples are motor transportation service, storage, and rental establishments, lawn suppliers, on-site photo processing and printing, underground storage tanks, storage of road deicing materials, and production of textile mill products.

Some prohibited uses are permitted as long as specific criteria are met. For example, storage of road salt is allowed if covered and located on an impermeable base. Underground storage tanks are permitted for residential dwellings provided that tank size is less than 300 gallons and the tank is in an enclosed basement. As shall be discussed, some exceptions and noticeably absent uses were not always excluded from the prohibition list. Just weeks before GPOD passage by the South Kingstown Town Council, individuals representing farming interests at the state and local levels lobbied Town officials to remove particular provisions that regulated farming. The Town conceded and the reasoning for that decision will be discussed.

\section{Site Design Standards}

The site design and construction standards outlined in the GPOD legislation apply to new and "substantial reconstruction" (30 percent of floor or land area) of existing uses, excluding single and two-family residential dwellings. There are ten separate items 
requiring best management practices in site design and use and standards are based upon those established in reference literature.

The specific provisions outlined in the ordinance regulate the storage of hazardous materials for farm use, interior floor drains, dumpsters, the collection of rainwater, stormwater runoff, in-sink garbage disposal units, site vegetation, commercial earth removal, and individual sewage disposal systems for flows of greater than 2,000 gallons per day.

Based on discussions with the South Kingstown Building Official and Director of Planning, the site design standards are not as effective as originally intended. In the legislation, the Building Official is responsible for overseeing compliance with site design requirements. At the time of issuing a building permit, the Building Official, Russell Brown, attests that any new or reconstructed use meets the requirements established in zoning. While he agrees that standards must be established to guarantee that the environment is protected, the Official disagrees in continually monitoring businesses for compliance with such standards. The federal government, DEM, and the Town all have a role in establishing standards for private industry. Brown considers multiple layers of governmental monitoring unnecessary, an overload of bureaucracy, and "harassment" of business owners (Brown 1997). Nor does he attribute lack of monitoring in GPOD to staffing shortages. The office has four, full-time employees and the Official concedes that staff would have time to monitor activities, if necessary, he says.

Site design standards therefore serve little purpose at present. Future building officials in South Kingstown and those in other municipalities who take a different 
philosophical stance on the role of local government might ensure greater adherence to established standards.

Regardless of monitoring mechanisms, site design standards are necessary because many activities accessory to permitted uses have the potential of contaminating water resources. For example, dumpsters for waste disposal are a necessary, accessory use for commercial and industrial activities. The Town permits dumpsters in GPODs but has imposed standards on their placement and maintenance. If no best management practices were included in the legislation, then the alternatives choices for the Town would be to prohibit dumpsters from GPOD, or to impose no standards. In this situation, neither option would achieve the desired effect. Yet as becomes apparent, monitoring by the Building Inspector might be necessary on occasion to make sure that dumpsters are covered, and that employees do not wash them on-site.

\section{Agriculture in South Kingstown}

South Kingstown was developed primarily as an agrarian community in the seventeenth century. This status was maintained well into the nineteenth century, and even after the advent of industry at the turn of the century the town retained its agricultural status (Rhode Island Historical Preservation Commission 1984). At the time of Comprehensive Plan preparation in the late 1980s, 786 acres in town were used for agricultural production, including cropland, orchards, and feeding operations. This represented approximately 2 percent of all land uses in 1990 (South Kingstown Comprehensive Community Plan 1992, I.13).

When South Kingstown adopted zoning in 1951, agriculture was a permitted use in any of the designated zones for residential, commercial, or industrial development. No 
agricultural zone was created, however, and the Town has never adopted such a zoning designation. According to the zoning laws followed by the Town today, agricultural uses are permitted in any of the zoning districts, with the exception of animal husbandry in high flood danger (HFD) districts (Town of South Kingstown Zoning Ordinance, Section 220).

A component of the zoning regulations that pertains to agricultural uses is Section 319. Prohibited are any uses associated with agriculture, field crop farms, livestock, general farms, that may "cause deleterious effects upon neighboring property, including...pollution of any waterways or waterbodies." As with oversight of existing uses in the GPOD, the statement raises important, if not rhetorical, questions of practicality and enforcement. Who ensures that farming operations do not affect groundwater quality? Is this standard enforceable?

The Environmental Protection Agency identified agricultural uses as the leading source of water pollution in the nation (Adler, Landman, and Cameron 1993) and other documents on groundwater protection verify that agricultural uses represent a threat to water quality (Connecticut Department of Environmental Protection 1989, Rhode Island Department of Environmental Management 1992, Jeer 1995b, Witten and Horsley 1995). Studies by researchers at the University of Rhode Island in the late 1980s and early 1990s indicate that manure-fertilized silage corn introduces considerable levels of nitratenitrogen into groundwaters. During two test years the nitrate-nitrogen levels of water supplies in close proximity to corn-production areas were in excess of the federal safe drinking water standards (Gold et al. 1990). Research findings associate high levels of nitrogen in drinking water with methemoglobinemia, a condition affecting young children 
that restricts the flow of oxygen through the bloodstream and can be fatal (Rhode Island Department of Environmental Management 1996, 1). Some nitrogen compounds have been identified as carcinogens (Witten and Horsley 1995). Practices associated with turf farming, common among farmers in South Kingstown, also introduces nitrogen to groundwater supplies. However, turf farming a smaller threat than is commonly perceived, and introduces fewer contaminants than corn production or septic systems (Gold et al. 1990).

Because all farmlands in the town are zoned for development, the Town should be concerned with maintaining the agricultural operations and associated benefits of open space and preservation of historic and rural character. Development in South Kingstown in the 1980s raised serious questions as to the long-term viability of farming in South Kingstown. Local officials are fairly optimistic about the Town's ability to maintain farming, as expressed by Council President Hackey at the 1991 GPOD public hearing, "[Land in South Kingstown] will be [farmed] until hell freezes over" (South Kingstown Town Council 1991).

South Kingstown experienced the greatest population growth of all Rhode Island communities between 1980 and 1990. A total of 2,139 building permits for residential development were issued in the decade. The population increased by more than 4,000 individuals between the 1980 and 1990 census enumerations, which represents a growth rate of 20.6 percent for that decade. The state's population grew 5.9 percent over the decade. The decade preceding the record-breaking 1980s saw similar population increases in town with absolute growth of 3,500 and percentage change of 20.7 percent. 
Agricultural land and operations were most certainly threatened by the rapidly expanding population and land speculation.

This concern with the loss of farming operations in South Kingstown parallels such concerns nationally. Communities everywhere are experiencing the loss of farmland to suburban residential developments (Arendt 1997, Daniels 1997). Specifically, an estimated 500,000 to one million acres of prime agricultural land is lost each year to expanding urban developments (Nelson and Duncan 1995, 38).

\section{Support for Local Agricultural Operations}

The language of the Overlay District legislation makes little mention of agricultural uses within the recharge areas. This despite the fact that a variety of farming practices represent real threats to groundwater.

The original text of the ordinance submitted for public and Council review on March 11, 1991 was not nearly as permissive. The drafters of the ordinance were selfprofessed "purists" who wrote an ordinance designed to serve for groundwater protection (Lachowicz 1997). Between the time of public review and Council adoption six weeks later, the Town solicited input from local farmers and state representatives. The following individuals are documented on record as contributing comments regarding the draft legislation.

1. Susan Sosnowski, South Kingstown Turf Farmer Meeting with Tony Lachowicz and Yael Calhoun April 1, 1991

2. Robert A. Caruolo, South Kingstown Turf Farmer

Meeting with Tony Lachowicz and Yael Calhoun April 1, 1991

3. Robert W. Sutton, Chairman DEM Agricultural Land Preservation Commission Letter to Town Council April 5, 1991

4. Kenneth D. Ayars, Senior Environmental Planner DEM Division of Agriculture Letter to Town Council April 8, 1991 
5. Michael Sullivan Ph.D., Associated Professor of Plant Sciences, Part-time farmer, Associate Director of the Southern Rhode Island Conservation District Letter to Town Council April 8, 1991

Each of the above individuals addressed their concerns with the proposed groundwater protection legislation. The concurring opinion among them was that the legislation as written, would negatively affect the few remaining farming operations in the town and could have the potential effect of eliminating these limited operations through over-regulation.

\section{Efforts to Preserve Agriculture}

Concern with continued farming operations has received tangible support from state-level agencies. The General Assembly acknowledged the growing threat to farmers from expanding residential developments with the passage of the Rhode Island Right to Farm Act in 1982 (RIGL 2-23-1). The legislation protects farmers from nuisance actions arising from conflicts between agricultural operations and urban land uses.

Also beginning in the mid 1980s, DEM's Agricultural Land Preservation Commission (ALPC) purchased development rights for several South Kingstown farms located in the West Kingston area under the terms of the Agricultural Land Preservation Act. The State invested more than one million dollars to purchase the development rights to five farms, four of which are located in West Kingston and a groundwater protection overlay area. Total land purchased amounted to approximately 400 acres, 350 of which are located in West Kingston in the GPOD (Sutton 1997). This required significant effort at the state and local levels, and at the time of GPOD legislation represented the largest concentration of farmland for which development rights had been purchased in the State 
(Ayars 1991). Both representatives of the ALPC implied that the investment in continued farming operations in South Kingstown could be lost if GPOD passed as proposed in 1991. Professor Sullivan wrote that, "unnecessary constraints on viable farm operations will result in fewer farming operations and a loss of valuable open space" (Sullivan 1991).

\section{Opposition to Provisions within GPOD}

Farmers identified at least seven different items in the legislation that could have adverse impacts on local operations. The exact wording of each of the problematic items is identified below followed by an explanation of the problem, and local response to the voiced concern.

Prohibited Uses Section 2021-2 "General automotive service and repair shops, including repair to...farm or lawnmowing equipment...Included among these uses are establishments which sell, store, lease, or rent such equipment and which include service and repair as accessory activities."

Following input from the aforementioned individuals, an additional provision to this item was included: "Non-commercial repair work, or repair work incidental to a permitted use is not prohibited." This assuaged concern that private farmers would not be permitted to repair their own farm equipment, an activity accessory to the permitted use of farming within the GPOD.

Prohibited Uses Section 2021-13 "Livestock farms, animal husbandry services, or other raising or breeding of animals exceeding 25 animals per acre" 
This item was eliminated completely from the legislation and in the current zoning provisions there is no statement limiting the raising of livestock within a groundwater district. The original intent of the provision was to "prohibit a situation in which a high number of animals would produce waste that could add excessive nitrogen to the groundwater" (Lachowicz 1991). According to the memo from Sullivan, all animals received equal treatment in the legislation when in fact all animals do not contribute equally to nitrogen loading (Sullivan 1991). The apparent intent was not to eliminate but to modify the wording. The Town opted to eliminate the controversial language because of farming's long and unique history in South Kingstown, and because animal husbandry represented a small percentage of all local agriculture (Lachowicz 1997).

Prohibited Uses Section 2021-15 "Land disposal of septage or sewage sludge" The section was amended to read "Land disposal of septage or sewage sludge. Not prohibited is the application of wastewater treatment facility composted sludge, applied according to RIDEM 'Rules and Regulations Pertaining to the Treatment, Disposal, Utilization, and Transportation of Wastewater Treatment Facility Sludge, 1991."' Memos from Lachowicz to the Town Manager and from Sullivan to the Council cite the use of composted sludge as a common and agriculturally beneficial farming practice.

Prohibited Uses Section 2021-16 "All uses which involve the use, storage, or generation of hazardous or toxic waste or materials...provided that minor or insignificant quantities may be stored on the premises." According to the initial draft, the Building Official was charged with the responsibility of deciding if the presence of any toxic material is 
insignificant and poses no threat to area groundwater resources. Concerns were raised that the Building Official is not in a position to determine if a substance is an insignificant amount or not particularly regarding fertilizers and pesticides used in agricultural operations. The section was therefore amended to include the provision that the Building Official must obtain written opinions of appropriate DEM offices in determining if a particular material is toxic and/or insignificant

Prohibited Uses Section 2021-19 "The parking of vehicles for the storage or delivery of fuel oil or other hazardous or toxic materials for a period exceeding two (2) hours in any twenty-four (24) hour period."

A clause was added that states " $[\mathrm{t}] \mathrm{his}$ shall not prohibit the use of vehicles for delivery of fuels or for application of fertilizers, pesticides, or herbicides to any use permitted by this ordinance." Farmers were concerned that the provision would not permit agricultural operators to apply necessary fertilizers and pesticides from the back of a truck, as is commonly done in agriculture operations.

Of additional concern were provisions in site design standards (Section 2030) regulating outdoor storage tanks for petroleum and hazardous or toxic materials (Section 2030-2). Also, all earth removal operations were restricted through the original language of the GPOD legislation through separation distance between excavation and seasonal high water, and requirements for soil erosion and sediment control measures (Section 2030-9).

In addressing both of these concerns, the Town specifically excluded portable fuel tanks for farm uses in the regulation of storage tanks. The standard addressing earth 
removal was modified to read "Commercial earth removal...excluding construction necessary for new farm ponds, new drainage structures, and new farm road, as provided by RI General Laws Title 2, Chapter 1, Section 22."

Of prime importance in the revised language of the GPOD legislation is an additional clause in the statement of purpose: "It is further the intent of this Article to permit the use of land within the GPOD for agricultural purposes, and to encourage the use of farmland in a manner which is consistent with protection of surface and groundwater resources."

One final concern was raised by a state official in the prohibited uses section of the draft legislation. Item 18 prohibited all underground storage tanks except those of 300 gallons or less used to store home heating oil. A DEM representative voiced concern that such regulation of USTs, commonly used in farming activities, would detrimentally affect local farming operations (Ayars 1991). No recorded discussion ensued on the topic. Underground storage tanks are of serious concern in groundwater protection (Rhode Island Department of Environmental Management 1993, Jeer 1995b) and the provision remained in the article.

\section{Assessment of Municipal Response}

The failure of South Kingstown's adopted overlay district legislation to regulate farming uses is not necessarily surprising. At the time of GPOD adoption, Town officials were faced with two distinct choices: To address nonpoint source pollution of drinking water or to help maintain farming operations in town. Even with DEM's purchase of development rights to the four farms in West Kingston, continued economic viability could have been threatened by regulation in GPOD (Alfred 1997). 
Based on the language of GPOD as adopted, a concern with continued farming outweighed the need to reduce the risks of drinking water contamination from farm practices. Moreover, although the provisions in the original text of the legislation are not completely prohibitive, the restrictions they would have placed on local farmers were threatening to continued farming viability (Ayars 1991, Sullivan 1991, Sutton 1991).

Lack of controls for farming operations in aquifer and recharge ordinances is not uncommon in Rhode Island. Of seven other communities with overlay zoning, the towns of North Smithfield and Burrillville explicitly exempt agriculture from all overlay controls. Richmond, Exeter, Tiverton, and Middletown make no mention of agricultural activities in their ordinances, and North Kingstown allows agriculture through special permitting. In North Kingstown agricultural uses are, however, exempt from site plan review, a process required for all other uses in the overlay areas. As has become apparent, other Rhode Island communities are struggling with questions similar to those facing South Kingstown at GPOD adoption. How can the community encourage both safe water supplies and continued occupation of the land by desired uses?

Concern here seems to be with the long-term availability of the resources. Once polluted, remediation of contaminated waters are prohibitively expensive (Witten and Horsley 1995,15$)$. Remediative efforts are necessary to permit human consumption of a once-contaminated water supply. Natural processes of filtration of impurities from contaminated groundwater is a very long process, depending on the type of pollutant, and even then cleansing of water is never guaranteed (Witten and Horsley 1995). Potability of drinking water supplies can be enhanced through sanitation measures and new wells can be drilled, as long as the finite resource remains available. 
Recovering open space and agricultural uses is far more difficult after land development. One option employed is conversion of marginally productive farmland into active agricultural use. Often accomplished through heavy applications of chemicals, the methods are expensive and environmentally dangerous (Nelson and Duncan 1995, 38). In South Kingstown the choice to convert marginal lands to productive farmland is not a viable option because many undeveloped parcels of significant size are protected or bordering environmentally sensitive regions.

When the costs of farming far outweigh profits for development, local farmers will be forced to sell their land for alternative uses. And although not explicitly stated during the public hearings or in any of the town files, Town officials balanced their desire to maintain one or the other of two precious natural and historic resources, and decided on that which is most irreplaceable. 


\section{V: Evaluation and Applicability}

Thus far, the discussion of wellhead protection and techniques to be used have been applied only to South Kingstown. The efforts undertaken in the town have included a variety of techniques including large lot zoning, a groundwater protection overlay district, and fee simple land acquisition. The requirements of the Safe Drinking Water Act and the Rhode Island Wellhead Protection Program call for the Town to assess these strategies and supplement them as needed in order to continue adequate protection of the town's drinking water supplies.

\section{Groundwater Quality in South Kingstown}

A 1991 classification of the groundwater aquifers that form the Pawcatuck Watershed by DEM resulted in their qualifying as GAA aquifers, indicating that water is safe for drinking without treatment. The high quality rating was reinforced during Wellhead Protection Plan preparation through Planning staff review of water test results from the Rhode Island Department for a five year period (1991-1996). Incidences of contaminants approaching or surpassing SDWA maximum contaminant levels (MCL) were reported at each of the wells at various times. The following matrix displays incidences of contamination detection.

\begin{tabular}{|c|c|c|c|c|c|}
\hline Contaminant & Allens Health Center & KWD & S.K. South Shore & URI & UWRI \\
\hline Aldicarb & N/A & 3 & 2 & N/A & 1 \\
\hline Benzene & N/A & N/A & $N / A$ & 1 & N/A \\
\hline Di Adipate & $\mathrm{N} / \mathrm{A}$ & $\mathrm{N} / \mathrm{A}$ & 1 & N/A & $\mathrm{N} / \mathrm{A}$ \\
\hline DI Phthalate & 1 & 1 & 1 & $\mathrm{~N} / \mathrm{A}$ & N/A \\
\hline Lead & N/A & 1 & N/A & 1 & 3 \\
\hline Metolachlor & N/A & N/A & N/A & 3 & 6 \\
\hline Nitrate & $\mathrm{N} / \mathrm{A}$ & 1 & $\mathrm{~N} / \mathrm{A}$ & N/A & 1 \\
\hline Sodium & 3 & N/A & $\mathrm{N} / \mathrm{A}$ & $\mathrm{N} / \mathrm{A}$ & $\mathrm{N} / \mathrm{A}$ \\
\hline
\end{tabular}


Description of Contaminants

Aldicarb A pesticide used on potatoes and beets. Banned in Rhode Island. Can affect the nervous system, has no cancer classification.

Benzene Natural component of crude oil and gasoline. Commonly used in chemical production. Primary source in groundwater is from leaking USTs. Human carcinogen and has been shown to damage blood and immune systems of animals.

Di Adipate Industrial chemical and plasticizer. More commonly detected in chemicals in Rhode Island. Evidence suggests that it is introduced to water supplies from plastic materials used in treatment or distribution systems. Carcinogenic in mice; possible human carcinogen.

Di Phthalate Industrial chemical and plasticizer and is used to make plastics more flexible. Commonly detected in chemicals in Rhode Island with evidence suggesting that is introduced to water supplies from plastic materials used in treatment or distribution systems. Possible human carcinogen, and in test animals has caused cancer, damage to liver and male reproductive systems, and resulted in birth defects.

Metolachlor Herbicide used to control grass and weeds. Applied around wide variety of plants including corn, turf, landscape plantings, and potatoes. Possible human carcinogen.

Nitrate Compound derived from manure-based fertilizers and human and animal waste. Possible carcinogen. Adversely affects children and can cause "blue baby syndrome."

Sodium Naturally occurring element. Can enter groundwater supplies from industrial waste, sewage, road salt storage and application, intrusion in coastal areas. Normally presents no health risks if in water supplies (Rhode Island Department of Environmental Management 1996).

Except for the detection of Metolachlor at two of the United Water Rhode Island

wells on three separate occasions in 1994, the incidences of contaminants detected in local water supplies were fairly isolated incidences during the five year period. As such, contamination was never widespread. At no time were all the wells servicing a supplier affected, nor were supplier wells that draw from the same aquifer ever affected simultaneously.

The Department of Health requires that re-testing of wells occur immediately upon detection of contaminants approaching or exceeding a maximum contaminant level 
(MCL). Wells are taken off-line, disinfected, and retested. If necessary, a well will be closed to prevent adverse health effects on residents (Haviland 1996). At no time in the five year test period were any of the local wells closed for an extensive period of time.

\section{Applicability of Measures to Other Pawcatuck Watershed Communities}

The previous discussion indicates that, thus far, the Town of South Kingstown has been able to preserve water supplies from serious contamination, even as the town underwent serious development during the 1970s and 1980s. This section more thoroughly assess some of the techniques discussed in chapters 2 and 4 through application to other communities. The tools for protection in South Kingstown will be considered as part of a whole groundwater protection agenda. Certain techniques have proved more useful than others, while other tools have not been used to their full advantage. An assessment will not address all tools for protection that are available, rather those thus far employed by the town and their applicability to other Pawcatuck Watershed communities. None of these communities has yet formally submitted state mandated wellhead protection plans. The preparation of wellhead plans provides an ideal opportunity for communities to assess their own needs and to gain insight in the practicality of given techniques based on the experiences in South Kingstown.

The majority of South Kingstown's programs are regulatory, as discussed in chapter two. Zoning regulations, with minimal requirements through subdivision legislation, substantially cover the do's and don'ts, should's and shouldn'ts, for

preserving water potability. Supplemented by limited strategies for long-term 
preservation of undeveloped land in recharge areas, the result is a solid framework for groundwater protection.

The strength of the South Kingstown agenda is that permitted and prohibited uses are clearly identified. The Town has also demonstrated considerable effort in encouraging groundwater-conscious policies such as cluster subdivision options, the potential for environmental impact review for developments within an overlay district, and best management practices for facility maintenance over aquifers.

A formal assessment of regulatory strategies employed in nine neighboring communities, all part of the Pawcatuck Watershed, has not been completed. However, research indicates that six of these municipalities, the Towns of Charlestown, Coventry, East Greenwich, Hopkinton, West Greenwich, and Westerly do not have specific legislation to govern uses within recharge or wellhead protection areas. However, representatives form each town indicated that such legislation will be adopted in the future. Also obvious through discussions is the shared concern to protect groundwater reserves. The towns of Exeter, North Kingstown, and Richmond also part of the Pawcatuck Watershed, have adopted overlay ordinances.

In considering which policies to adopt for groundwater protection, officials from each community can learn from the experience to date in South Kingstown. The following recommendations are intended for any community seeking to protect water supplies and most specifically for communities that, with South Kingstown, share the Pawcatuck Watershed. 


\section{Application of Regulatory Techniques}

In groundwater overlay districts, clearly indicate uses that are and are not prohibited.

In determining the potential for future impacts from development, GPOD authors

considered all potential activities based on zoning regulations and eliminated uses that could adversely affect groundwater reserves. The prohibited uses section of the GPOD is extensive and comprehensive, particularly regarding commercial and industrial activities. Although not many areas are now zoned for intense development, it is possible that future decisions could result in parcels being zoned for industry or commercial development over an aquifer. Should this occur, uses most detrimental to groundwater quality are now prohibited.

Unlike several other Rhode Island communities, South Kingstown specifically stated in the opening section of the GPOD legislation that farming uses were not to be eliminated or regulated by the legislation. Several towns in which the potential for farming exists, Richmond, Exeter, Tiverton, and Middletown, do not specify how farming uses fit into groundwater legislation. This has the potential for questions or conflict in the future.

Rely less on site design standards within zoning legislation unless certain that long-term staff oversight can be provided.

Due to staffing shortages, a common problem in many municipalities, as well as philosophical differences regarding the role of government officials in regulating private property, reliance on site design standards could prove futile. Site standards supplementary to prohibited uses may serve a purpose if the standards will be enforced. If an activity will contaminate groundwater resources without appropriate site maintenance and town oversight cannot be guaranteed, then either prohibition of the use or an alternative means of enforcement must be developed. 
Consider the secondary effects of strategies for groundwater protection that could negatively influence natural resources or other important attributes of the community.

Large lot zones of two and five acres were adopted in the past decades to foster protection of groundwater resources. While one effect has been lack of dense growth in recharge areas, a secondary effect of large lot zoning is sprawl. Zoning for two, five, and even ten acre residential development fosters growth that gobbles up acres of land (Arendt 1997). Long-term effects of such zoning could actually further damage water supplies because of the miles of needed roads and ensuing vehicles, runoff, and salt applications in winter months.

A resource critical to the history and character of South Kingstown is agriculture. Monetary benefits, preservation of rural character, and sustaining a historic precedence are all highly valued by residents of the Town and the state in general. The adverse effects of regulating farming activities within groundwater overlay districts was not known until farmers had an opportunity to comment on the regulation. It was at this time that Town officials decided to eliminate some of the controversial provisions.

Very particular attention needs to be paid to long-term consequences of policies. Even if well-intentioned, the effects of programs can have long-term adverse impacts on many facets of a community.

\section{Application of Non-Regulatory Techniques}

Ideal protection of groundwater reserves will occur if development is prevented from within source areas. Encourage programs that will inhibit growth in critical resource areas.

Traditional methods of guiding development such as zoning regulations, subdivision controls, and building codes have been viewed as incapable of effectively channeling development and controlling impacts, including environmental. For this 
reason alternative forms of managing development away from sensitive areas are now advocated (Deakin 1990, Nelson and Duncan 1995). Purchase and transfer of development rights, easements, and fee simple acquisition are all measures that have the potential of more effectively directing growth and preserving natural resources.

South Kingstown has not engaged in any TDR programs, but there is local experience in PDRs, easements, and land purchase. Acquisition of properties has occurred in critical recharge areas, and for the purpose of protecting farming activities. In most cases the Town was a party to the property exchanges: the State and local nonprofits led purchases of development rights, fee simple acquisition, and attainment of easements.

Consideration of innovative strategies is mandatory for towns interested in fostering long-term groundwater protection. Alternative tools discussed above should be used in addition to traditional measures. This will result in a comprehensive program that can creatively guide development away from sensitive areas.

Make education a central element of any groundwater protection program.

The requirements handed down from DEM require that education be a part of wellhead protection. Based on an assessment of South Kingstown's strategies to date, the mandate is well-taken. Education must complement any other techniques, whether regulatory or incentive-based development, to gain acceptance for water management in a community. If town residents do not understand the importance of protecting water supplies, cooperation and acceptance of programs will be much harder to achieve.

Moreover, residents need to learn the ways in which their individual efforts can complement town-wide efforts to protect water supplies. Actions by individual 
homeowners in septic system maintenance, disposal of hazardous household materials, and application of lawn chemicals could potentially have long-term, positive effects on the quality of drinking water supplies. 


\section{VI: Conclusions}

The research culminating in completion of this study led to several distinct conclusions about implementation of wellhead protection. While local implementation of the Safe Drinking Water Act has its shortcomings, such as a lack of financial resources, a singular strength of the mandate is that local have both the opportunity and responsibility of developing a program that will address needs particular to the community. The requirements presented by the federal and state governments are designed to guide program development, but do not dictate either form or content of any program.

In South Kingstown the requirements have permitted a year-long, comprehensive evaluation of existing programs and their strengths and weaknesses. The Town, while effectively attempting to address groundwater issues in the past, has not before so thoroughly assessed needs and strategies.

Despite this opportunity, questions remain as to what actual recommendations for wellhead protection will be approved by local residents and the Town Council. As was demonstrated in 1991 with passage of the GPOD ordinance, considerations other than a need to protect water supplies factored into legislative content. Local farming interests and historical significance of agriculture played significant roles in shaping the zoning amendment. Influences in the adoption and implementation of the Wellhead Protection Plan remain unidentified at this point in time.

It has also become clear through research that the Town of South Kingstown needs to focus efforts to preserve all significant resources, not only groundwater reserves. Despite rapid growth in the past two decades, the Town still maintains remarkable natural and historic resources. Salt ponds in the south, upland moraine in the mid-sections of 
town, tracts of agricultural land in the west, and the historic village of Kingston all contribute to the character of the town. To preserve these qualities while addressing anthropocentric needs of safe water supplies must be collectively pursued. Innovative methods of regulation, directed growth, and widespread community education can secure these unique qualities.

Significant attention needs to be paid to regional efforts. It is a recognized phenomenon that communities in the United States too often focus only on the needs within their municipal boundaries. This is true for issues as diverse as preservation of natural resources, provision of affordable housing, and creation of jobs. As more knowledge becomes available on the detrimental effects of these strategies for municipal self-preservation, it becomes increasingly clear that regional perspectives need examination. Rhode Island communities do not benefit from oversight by a county government, unlike many places in the nation, so a regional perspective on groundwater protection will need to begin from within the communities themselves. Even the Department of Environmental Management does not strongly advocate a regional approach. This is a conspicuous weakness of the state program.

Fortunately for South Kingstown and the other communities of the Pawcatuck Watershed, resources already exist in the form of non-profit organizations and entities associated with the University of Rhode Island. South Kingstown and the neighboring municipalities can access these resources to develop cooperative approaches to drinking water protection. This is crucial for long-term protection of supplies.

As alluded to previously, no local laws or programs exist to address water quantity withdrawals. This is a cited criticism of South Kingstown's groundwater efforts 
(Spizuoco 1991). However, it must be recognized that without Rhode Island State legislation either establishing limits on withdrawal rates and amounts, or enabling legislation for town's to develop such standards, no local action can occur (Lachowicz 1997, Panciera 1997). Several years ago proposals for a cogeneration plant at the University in Kingston resulted in critical concern that the Chipuxet aquifer could face considerable reduction of source waters (Lachowicz 1997). The plant was blocked from construction. Other proposals for similar uses requiring vast quantities of water in South Kingstown, elsewhere in the Watershed, or at a different location in the State, still exist. The General Assembly needs to address this issue before it is too late.

Finally, local efforts need to be directed toward resident awareness of groundwater issues. Mandates at the State level supplemented by several recommendations within the local plan address education. Residents and business owners in South Kingstown must be made aware of steps that they can take to protect the quality and quantity of groundwater supplies.

This insight returns the discussion to criticisms of the Safe Drinking Water Act as an unfunded mandate. Although federal policies have essentially fostered local actions that blatantly disregarded the environment, it is still local decisions that result in implementation of policies and associated degradation of natural resources. Efforts to mitigate these effects and prevent future harm to resources must then be applied locally. Local responsibility needs to be assigned and assumed to protect water supplies and must therefore rest not only with the elected officials and staff in local government, but with the many residents that comprise a community. 


\section{References}

Adler, Jonathan, ed. (1996). Environmental Briefing Book for Congressional Candidates. [Online]. Available: http://www.cei.org/ebb/sdwa.html [1997, April 17].

Adler, Robert W., Jessica C. Landman, and Diane M. Cameron. 1993. The Clean Water Act 20 Years Later. Washington D.C.: Island Press.

Alfred, Stephen, South Kingstown Town Manager. 1997. Interview by author. 3 April, South Kingstown.

Arendt, Randall. 1997. Basing Cluster Techniques on Development Densities Appropriate to the Area. Journal of the American Planning Association. 63:1 (Winter) 137-144.

Ayars, Kenneth D. 1991. Letter to South Kingstown Town Council, 8 April. South Kingstown Planning Department Files.

Brown, Russell, South Kingstown Building Official. 1997. Interview by author, 25 March, South Kingstown.

Collins, Clarkson, President of South Kingstown Land Trust. 1996. Interview by author, 16 June. South Kingstown.

Connecticut Department of Environmental Protection, Bureau of Water Management, Planning and Standards Division. 1989. A Guide for Drafting Local Aquifer Protection Regulations.

Daniels, Thomas L. 1997. Where Does Cluster Zoning Fit in Farmland Protection? Journal of the American Planning Association. 63:1 (Winter) 129-136.

Deakin, Elizabeth. 1989. Growth Controls and Growth Management: A Summary and Review of Empirical Research. In Understanding Growth Management: Critical Issues and A Research Agenda, eds. David J. Brower, David R. Godschalk, and Douglas R. Porter, 3-21. Washington D.C.: Urban Land Institute.

Freeman, Myrick A. III. 1993. Water Pollution Policy. In Public Policies for Environmental Protection, ed. Paul R. Portney, 97-149. Washington D.C.: Resources for the Future, 1990; reprint, Washington D.C.: Resources for the Future (page references are to reprint edition).

Gardella, Mark C. and Richard C. Ribb. 1991. A Wellhead Protection Program North Smithfield, Rhode Island. Master's Research Project, University of Rhode Island. 
Goetz, Edward G. 1993. Shelter Burden: Local Politics and Progressive Housing Policy. Philadelphia: Temple University Press.

Gold, Arthur J., William R. DeRagon, W. Michael Sullivan, and Jerrell L. Lemunyon. 1990. Nitrate-nitrogen Losses to Groundwater from Rural and Suburban Land Uses. Journal of Soil and Water Conservation. 45:2 (March-April) 305-310.

Haviland, Robert. Department of Health, Division of Water Quality. 1996. Interview by author, 26 November. South Kingstown.

Jeer, Sanjay and Jim Schwab. 1995. Zoning News: Zoning for Wellhead Protection. Chicago: American Planning Association, August.

Jeer, Sanjay. 1995. Appendix D. Sample Wellhead Protection Ordinance Provisions. In A Guide to Wellhead Protection, eds. Jon Witten and Scott Horsley, 67-102. Chicago: American Planning Association Planning Advisory Service Report Number $457 / 458$.

Lachowicz, Tony, South Kingstown Director of Planning. 1991. Memorandum to Stephen Alfred, Town Manager, 3 April. South Kingstown Planning Department Files.

Lachowicz, Tony, South Kingstown Director of Planning. 1997. Interview by author, 13 March, South Kingstown.

Masters, Phil. 1987. Groundwater Protection: South Kingstown, Rhode Island. Master's Research Project, University of Rhode Island.

Moskowitz, Harvey S. and Carl G. Lindbloom, eds. 1995. The New Illustrated Book of Development Definitions. Rutgers, 1993; reprint, New Brunswick: Center for Urban Policy Research.

Nelson Arthur C., James B. Duncan, Clancy J. Mullen, and Kirk R. Bishop, eds. 1995. Growth Management Principles and Practices. Chicago: Planners Press.

Nickerson, Raymond, South Kingstown Principal Planner. 1997. Interview by author, 30 April, South Kingstown.

Panciera, Ernie, Department of Environmental Management Groundwater Specialist. 1997. Interview by author, 26 March, South Kingstown.

Rhode Island Department of Environmental Management, Division of Groundwater and Freshwater Wetlands. 1990. Rhode Island Wellhead Protection Program.

Rhode Island Department of Environmental Management, Division of Groundwater and Individual Sewage Disposal Systems. 1992. Inventory of Potential Sources of 
Groundwater Contamination in Wellhead Protection Areas - RIDEM Guidance Document.

Rhode Island Department of Environmental Management, Office of Water Resources. 1996. Guidance Document for Municipal and Water Supplier Wellhead Protection Plans.

Rhode Island Historical Preservation Commission. 1984. Historical and Architectural Resources of South Kingstown, Rhode Island: A Preliminary Report.

Sierra Club. [Online]. Available: http://www.sierraclub.org/1996platform.html\#water [1997, April 12].

Spizuoco, William J. 1993. Pro-Active Management, Protection, and Apportionment of Conjunctive Water Uses in the Chipuxet Aquifer and River. Master's Thesis. University of Rhode Island.

State Enabling Act Relating to Land Use and Planning. 1995. Rhode Island Department of Administration, Division of Planning.

Sullivan, W. Michael. 1991 Letter to South Kingstown Town Council, 8 April. South Kingstown Planning Department Files.

Sutton Robert. W. 1991. Letter to South Kingstown Town Council, 5 April. South Kingstown Planning Department Files.

Sutton, Robert, Department of Environmental Management. 1997. Interview by author, 26 March, South Kingstown.

Town of South Kingstown Comprehensive Community Plan. 1992.

Town of South Kingstown Town Council. 1991. Public Hearing on Groundwater Protection Overlay District, audio cassette. South Kingstown Town Clerk's Office. 8 April.

Town of South Kingstown Utilities Department. 1994. South Shore and Middlebridge Systems Water Supply Management Plan.

Town of South Kingstown Zoning Ordinance. 1994.

U.S. Congress. Senate. Committee on Environment and Public Works. 1991. Implementation of the Safe Drinking Water Act. 102nd Cong., 1st Sess., 17 May.

Waxman, Henry A. 1994. Amending the Safe Drinking Water Act: View from Congress. EPA Journal. Summer v20 n1-2, 32(2). 
Witten, Jon, and Scott Horsley. 1995. A Guide to Wellhead Protection. Chicago: American Planning Association Planning Advisory Service Report Number $457 / 458$. 
Appendices 


\section{Appendix A}

Town of South Kingstown, Rhode Island

\section{WELLHEAD PROTECTION PLAN}

Prepared by the Town of South Kingstown Planning Department April 1997

$$
\text { draft copy }
$$




\section{TABLE OF CONTENTS}

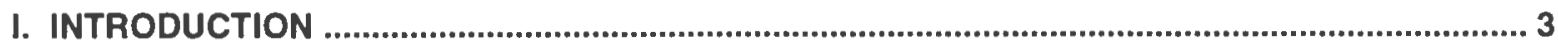

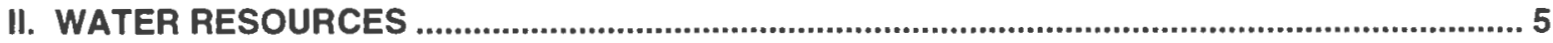

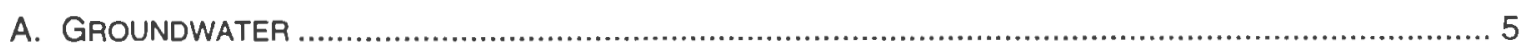

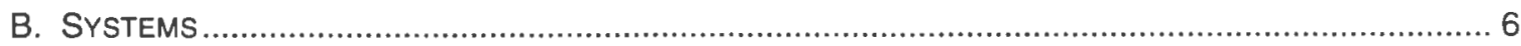

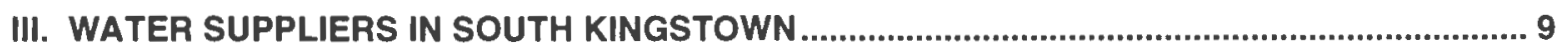

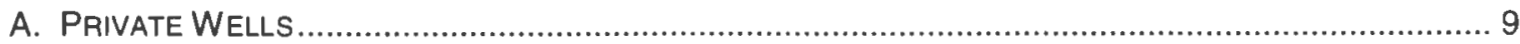

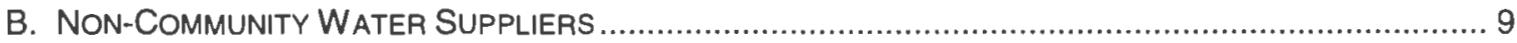

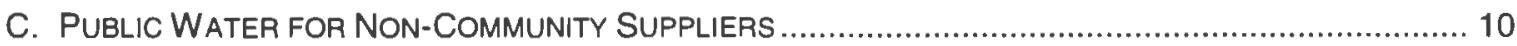

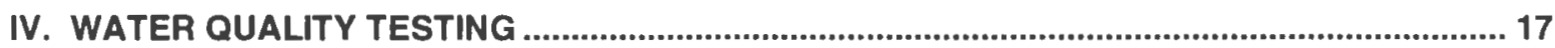

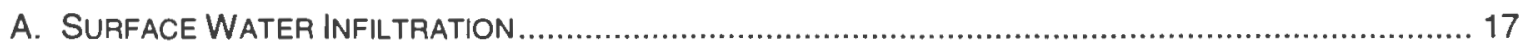

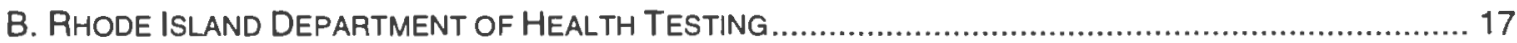

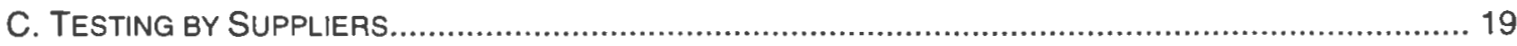

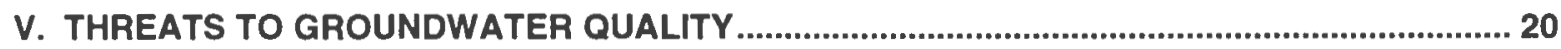

A. INVENTORY of Pollution Sites Within WELlHead Protection AREAS .................................. 20

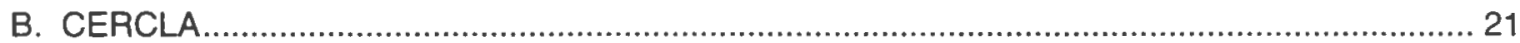

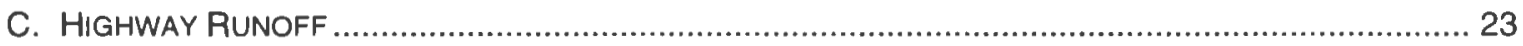

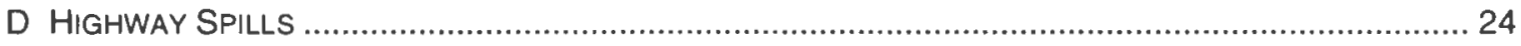

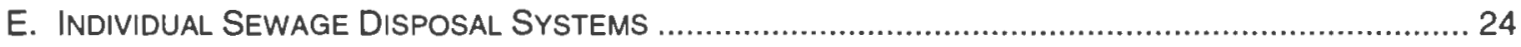

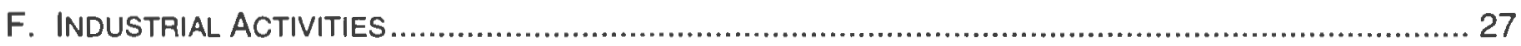

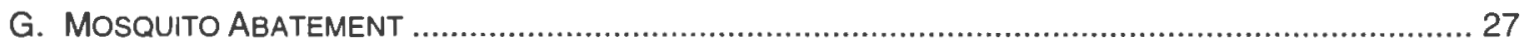

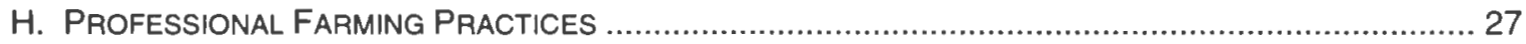

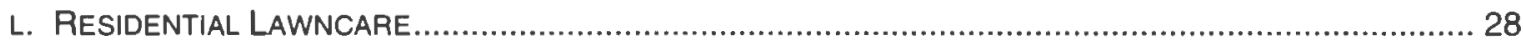

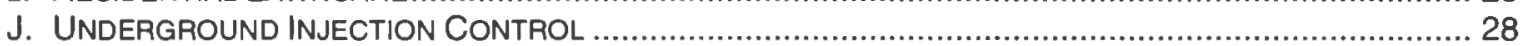

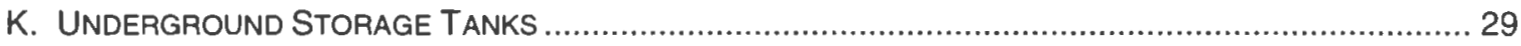

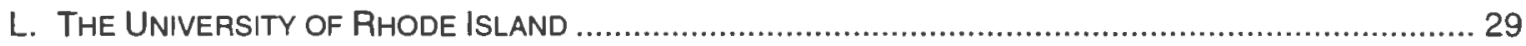

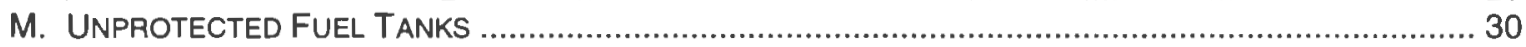

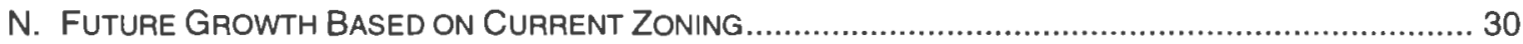

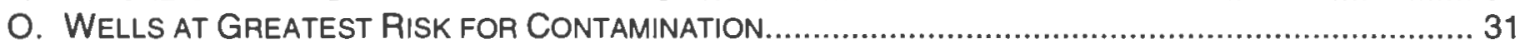

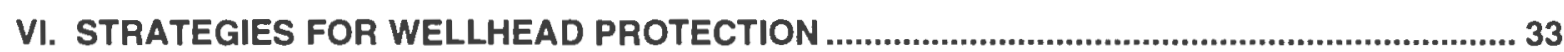

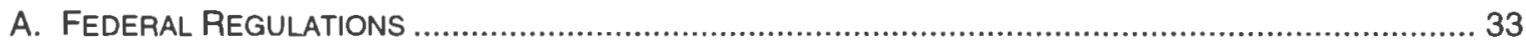

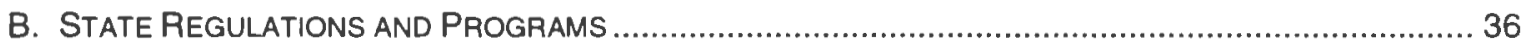

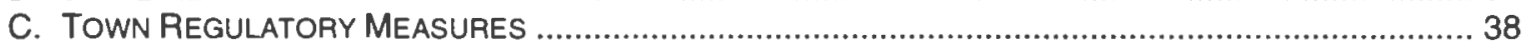

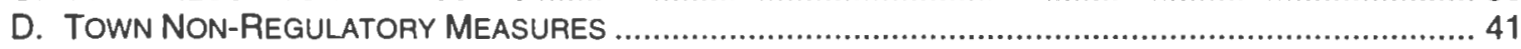

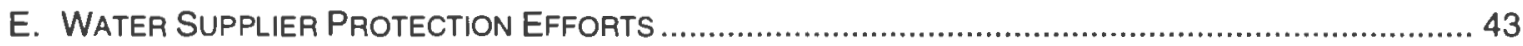

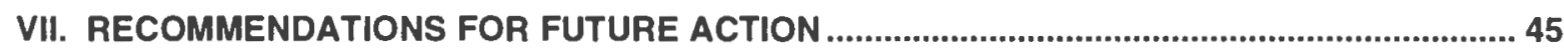

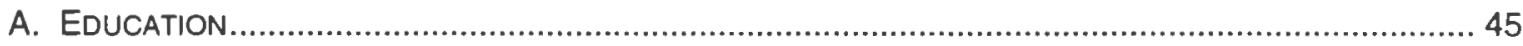

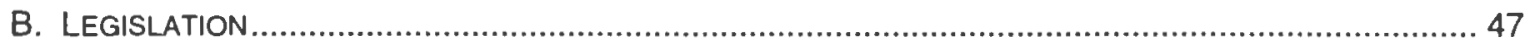

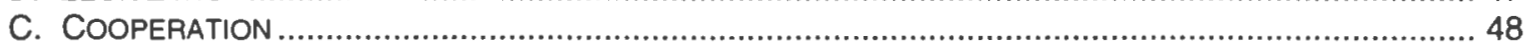

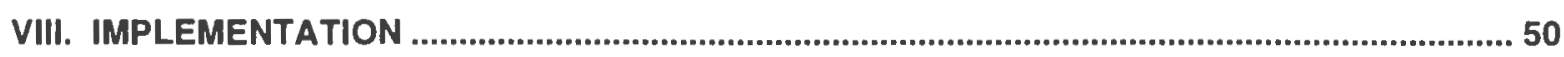

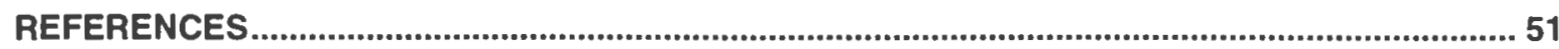




\section{LIST OF TABLES}

Table 1: Water Suppliers in South Kingstown ___ 6

Table 2: Non-Community Water Suppliers ___ 10

Table 3: South Kingstown Community Water Suppliers ___ 11

Table 4: Connections Serviced by Water Suppliers____ 12

Table 5: Department of Health Water Testing Requirements ___ 17

Table 6: Parameters Tested at Community Supplier Wells____ 18

Table 7: Detected Contaminants__ 18

Table 8: Testing Requirements for Coliform Bacteria ___ 19

Table 9: Two-way Traffic Counts for State Roads in South Kingstown ____ 23

Table 10: Sand and Salt Applications on Local Roads___ 24

Table 11: Residential Storage Tanks within WHPAs ___ 30

Table 12: Potential for Growth Based on Current Zoning within GPOD ___ _ _ 31

Table 13: Large lot Zoning over Groundwater Recharge Areas_____ 39

\section{LIST OF MAPS}

Map 1: Pawcatuck Watershed

Map 2: Wellhead Protection Areas in South Kingstown ___ 8

Map 3: Kingston Water District Well Locations _ 14

Map 4: Factory Pond Well Locations __ 15

Map 5: United Water Rhode Island Well Locations ______ 16

Map 6: Photek CERCLIS site and WHPAs ___ 22

Map 7: Sewer Service Areas in South Kingstown ___ 26 


\section{INTRODUCTION}

This Wellhead Protection Management Plan, prepared by the Town of South Kingstown Planning Department, was completed in compliance with Rhode Island General Law 46-13.1-9. The State law follows from the 1986 amendments to the Federal Safe Drinking Water Act (SDWA) mandating State preparation of a Wellhead Protection Program incorporating all localities. The amendments serve as guidance for land use management to ensure the quality of groundwater resources.

The Rhode Island law for wellhead protection states that each municipality shall pursue a series of measures culminating in development of management techniques to guarantee the quality of Rhode Island's groundwater. The Rhode Island Department of Environmental Management (DEM) Division of Groundwater and ISDS is the entity charged with overseeing wellhead plan preparation. In response to the 1986 Congressional amendments to the SDWA and the ensuing regulations promulgated by the Environmental Protection Agency, DEM prepared a four-phase Wellhead Protection Program for all municipalities and major water suppliers in Rhode Island.

Rhode Island's Wellhead Protection Program consists of the following components:

$\checkmark \quad$ Wellhead Protection Area Delineation: DEM determined the wellhead protection areas and the critical area of water contribution to the well for all community water suppliers, non-transient non-community systems, and transient non-community systems state-wide. DEM completed this first step of wellhead protection in 1993.

$\checkmark \quad$ Inventory of Pollution Sources: Each municipality and major water supplier was required to identify known and potential sources of groundwater contamination within its respective wellhead protection areas. The Town of South Kingstown completed inventories for thirteen wellhead areas in December 1995.

- Contingency Plan Preparation: DEM required water suppliers to complete contingency plans in the event of contamination of the wells or wellfield. The three major water suppliers in town each prepared emergency response plans for contingency planning as part of their Water Supply Management Plans.

$\checkmark \quad$ Wellhead Protection Plans: This plan is intended to serve as a management strategy for the Town of South Kingstown to prevent future contamination of groundwater resources. As a result of the inventory of potential sources of pollution and a discussion of existing strategies at the State and local level, Town leaders can identify issues and areas requiring greater attention. The strategies recommended in the plan will meet the unique needs of South Kingstown now and in the future.

\section{Consistency with the Comprehensive Plan}

The plan is consistent with the Town of South Kingstown Comprehensive Plan. The Natural Resources Element identifies the need for the town to protect its groundwater reserves. Specifically, the first goal of the Comprehensive Plan states that the Town will "protect and preserve the quality and quantity of the Town's potable water supply." Policies to reach this end include: 
- Implement strategies to preserve the water in the sole source aquifer, from which most town water is obtained.

- Link growth management plan to water availability for residential and non-residential uses.

- Give priority use to drinking water.

- Develop a town wide watershed management approach joining programs such as soil erosion, sediment control, and open space acquisition.

- Extend public water and sewers to the industrially zoned areas of West Kingston.

These policies are supported by fourteen implementation components which include adoption of the Groundwater Protection Overlay District, endorsement of State groundwater legislation, and development of public education strategies for groundwater-related issues. 


\section{WATER RESOURCES}

\section{A. Groundwater}

Groundwater and surface water bodies, including rivers and ponds, comprise a very complex and interrelated system of water in the South Kingstown area. The Pawcatuck Watershed (Map 1) is a 194,000 acre land basin which provides the source for much of this water. Many rivers and streams, as well as rainfall and snowmelt, drain into this common outlet. The Watershed encompasses four Connecticut and portions of ten Rhode Island communities, is drained by seven rivers and their tributaries, and includes numerous lakes, streams, and wetlands. More than half of the land within the watershed (116,560 acres or 60 percent) is forests or wetlands (1990 RIGIS data). As of 1990 , less than ten percent (10 percent) of total land within the watershed was developed. The watershed serves critical functions for drinking water supplies, wildlife habitat, human recreation, and agricultural production.

In addition to surface water bodies, the Pawcatuck is also underlain by ten aquifers. An aquifer, generally defined, is a formation of stratified sand, rock, and/or gravel capable of yielding large quantities of water. According to one source, the aquifers of the Pawcatuck Watershed yield ten million gallons of water daily (McCann 1991).

Central to these high yields of water in this region is the soil composition. According to the United States Geological Survey (USGS), aquifers can be formed by a wide variety of rock compositions including fractured rock composition, coastal plain deposits, and sand and gravel fill, as found in the Pawcatuck Watershed. The ease with which water can be withdrawn from the source signifies that the groundwaters are prone to contamination.

In 1992 DEM adopted a groundwater classification system as part of the "Rules and Regulations for Groundwater Quality." In this classification system, all the groundwaters in the State of Rhode Island were ranked in one of the following four categories:

- GAA - Groundwater sources suitable for public drinking water use without treatment.

- GA - Groundwater sources which may be suitable for public or private drinking water without treatment.

- GB - Groundwater sources which may not be suitable for public or private drinking water without treatment due to know or presumed degradation.

- GC - Groundwater sources which may be suitable for certain waste disposal practices because past or present land use or hydrogeologic conditions render the groundwaters more suitable for receiving permitted discharges than for development as public or private water supply (RIGL 46-13.1).

The aquifers of the Watershed that lie in Rhode Island received designation as GAA aquifers by the Department of Environmental Management. In addition to such classification, the waters comprising the Pawcatuck Watershed have been designated by the US Environmental Protection Agency as Sole Source Aquifers. This means that more than 50 percent of area populations obtain their drinking water from the aquifers, and that no reasonable and alternative source of water exists.

Three of the aquifers lie within the boundaries of South Kingstown. They are the QueenUsquepaug, the Chipuxet, and the Mink Brook. All three aquifers serve as sources of drinking water for South Kingstown residents, with both private wells and public community wells drawing from the reserves. 
A fourth source of drinking water for residents in the southern areas of town is the Factory Pond recharge area, delineated by DEM in 1991. The source lies in a coastal basin and provides water to the Town of South Kingstown's South Shore well system and numerous private wells.

\section{B. Systems}

The various water systems located in the State are defined by the numbers and types of individuals served on an annual basis. Community water systems serve at least 25 of the same individuals on a year-round basis. In addition to the above, there are numerous systems in town defined as non-transient non-community and transient non-community systems. Non-transient noncommunity systems serve at least 25 of the same persons over six months of the year. Transient non-community systems serve a minimum of 25 people at least sixty days of the year, although the system does not regularly serve the same people. Following are the types of water systems located in South Kingstown:

Table 1: Water Suppliers in South Kingstown

\begin{tabular}{ccc}
\hline Community & Non-Transient Non-Community & Transient Non-Community \\
\hline Allen's Health Center & American Power Conversion & Alternative Food Co-op \\
Kingston Water District & URI Liberty Lane & Card's Camp \\
South Kingstown Town & & Carriage House Inn/Champions Restaurant \\
United Water Rhode Island & DEM Fish and Wildlife \\
University of Rhode Island & Girl Scout Camp Hoffman \\
& Holiday Inn Wells \\
& Laurel Lane Golf Course \\
& Station House Restaurant \\
& Worden Pond Family Campground \\
\end{tabular}

Source: Rhode Island Department of Environmental Management

Map 2, provided by DEM Division of Groundwater, indicates the location of all community and non-community wells in South Kingstown. Note the concentration of wells in the northwestern area of town.

Although the primary focus of this plan will be on the community water suppliers, (URI, Kingston Water, United Water and the South Shore System), the town contacted and incorporated non-community water suppliers into the plan. 


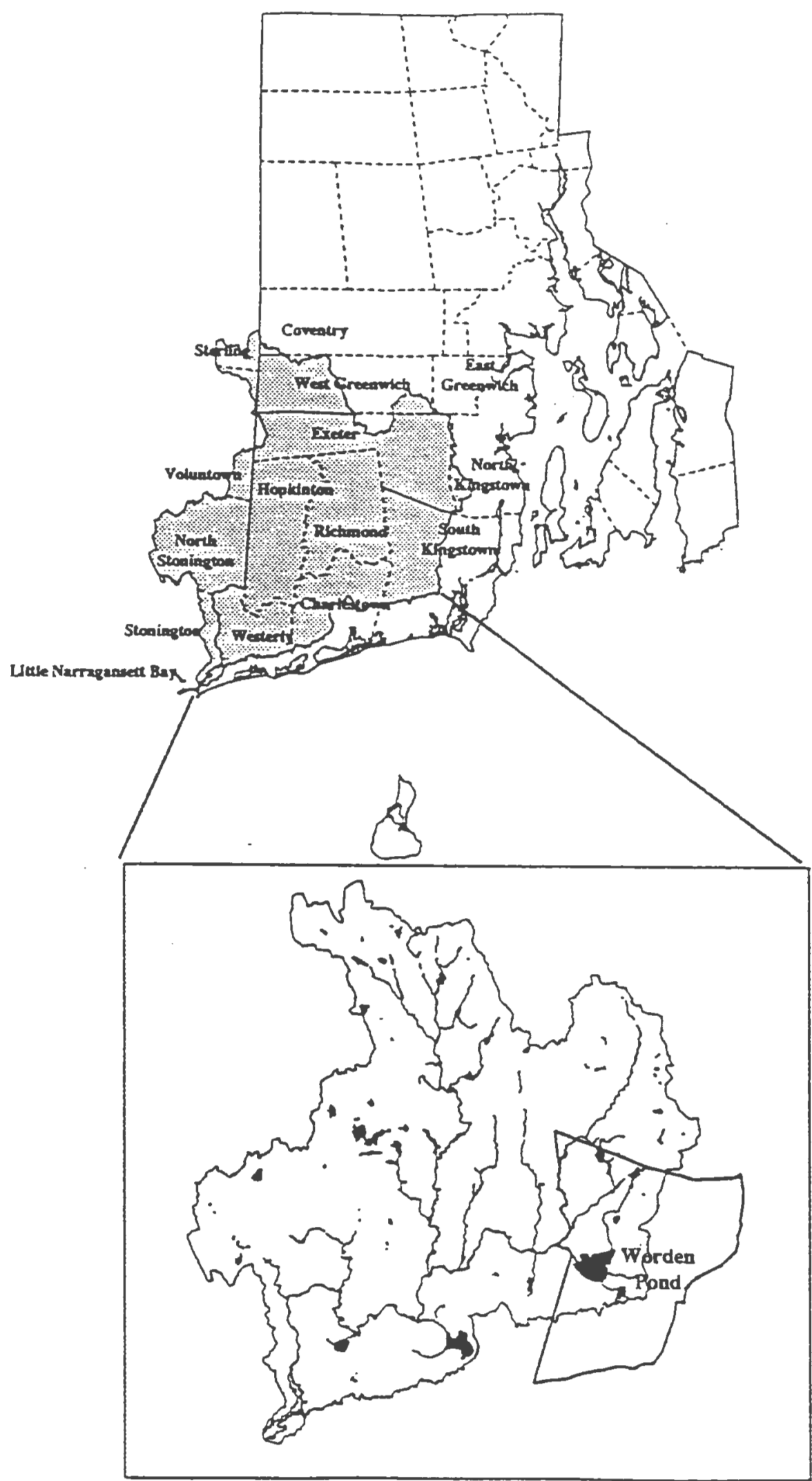

Major Hydrography of the Pawcatuck Watershed Basin

Source: Town of South Kingstown Comprehensive Plan 
State ID Numbers for Public Water Supply Wells in South Kingstown

\begin{tabular}{|c|c|}
\hline State 10 & Well Name \\
\hline 1000039 & URI-LIBERTY LANE \\
\hline 1615617 & AMERICAN POWER CONVERSION \\
\hline 1615623 & SOUTH KINGSTOWN TOWN SOUTH SHORE WELL \#1 \\
\hline 1615623 & SOUTH KINGSTOWN TOWN SOUTH SHORE WELL \\
\hline 1615624 & WAKEFIELD WATER COMPANY WELL \#1 \\
\hline 1615624 & WAKEFIELD WATER COMPANY WELL \#2 \\
\hline 1615624 & WAKEFIELD WATER COMPANY WELL \#3 \\
\hline 1615624 & WAKEFIELD WATER COMPANY WELL \#4 \\
\hline 1615624 & WAKEFIELD WATER COMPANY WELL \#5 \\
\hline 1615624 & WAKEFIELD WATER COMPANY WELL \#E \\
\hline 1858421 & KINGSTON WATER DISTRICT WELL \#1 \\
\hline 1858421 & KINGSTON WATER DISTRICT WELL \#2 \\
\hline 1858422 & UNIVERSITY OF RHODE ISLAND WELL \#2 \\
\hline 1858422 & UNIVERSITY OF RHODE ISLAND WELL \#3 \\
\hline 1858422 & UNNIVERSITY OF RHODE ISLAND WELL \#4 \\
\hline 2000127 & STATION HOUSE RESTAURANT \\
\hline 2000128 & QUALITY INN (HOLIDAY INN) \\
\hline 2000128 & QUALITY INN (HOLIDAY INN) \\
\hline 2000128 & QUALITY INN (HOLIDAY INN) \\
\hline 2000128 & QUALITY INN (HOLIDAY INN) \\
\hline 2000128 & QUALITY INN (HOLIDAY INN) \\
\hline 2882117 & ALLENS HEALTH CENTER WELL \#2 \\
\hline 2882117 & ALLENS HEALTH CENTER WELL \#3 \\
\hline 2882118 & CAMP FULLER/MCA \\
\hline 2882119 & CAMP HOFFMAN \\
\hline 2882126 & LAUREL LANE GOLF COURSE \\
\hline 2882130 & WORDENS POND FAMILY CAMPGROUND \\
\hline 2882130 & WORDENS POND FAMILY CAMPGROUND \\
\hline 2980022 & TOWER HOUSE CORPORATION \\
\hline 2980171 & DEM DIVISION OF FISH AND WILDLIFE \\
\hline 2980199 & CARDS CAMP \\
\hline 2980230 & ALTERNATIVE FOOD COOP \\
\hline
\end{tabular}

Source: Rhode Island Department of Environmental Managentent

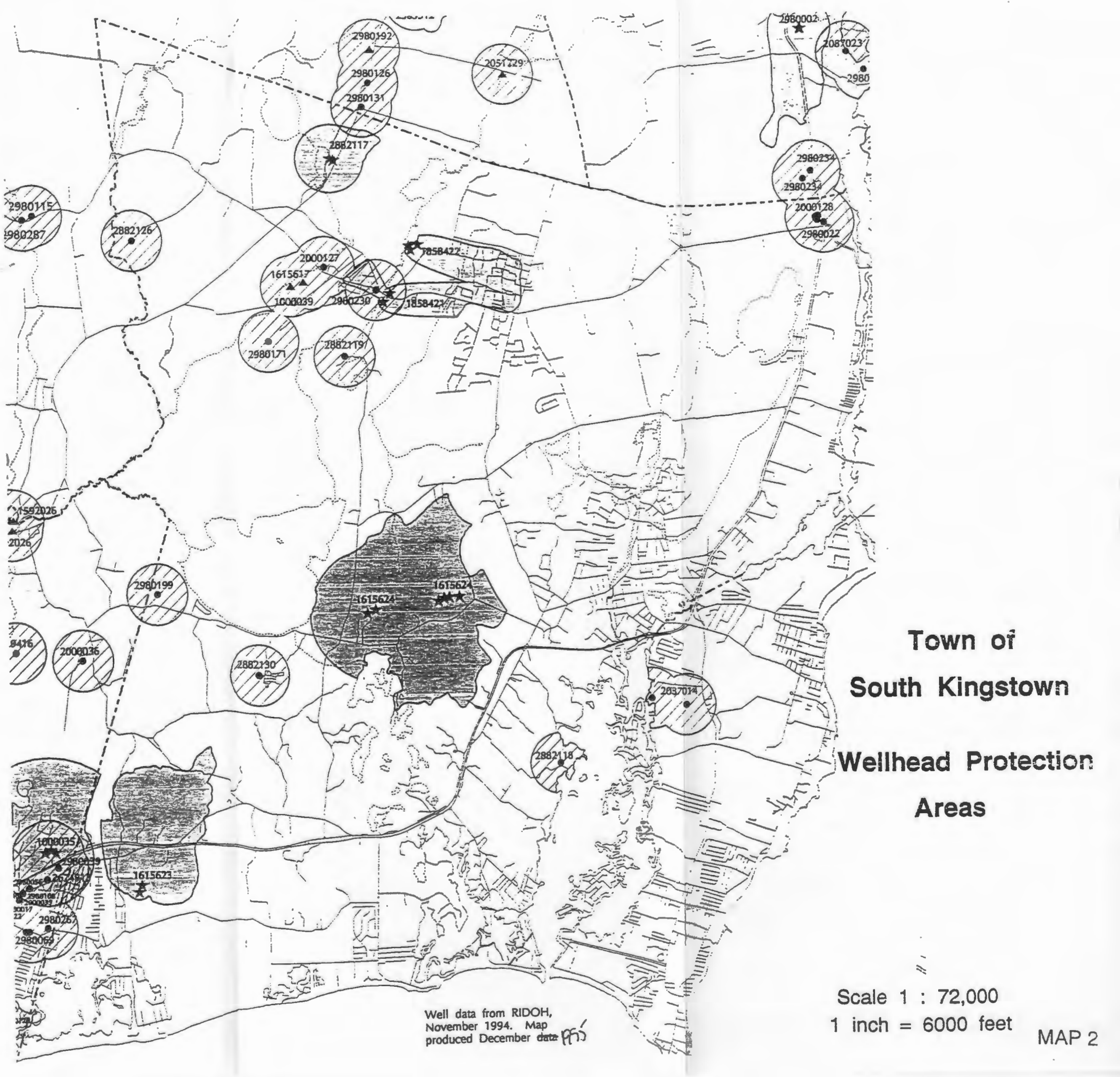




\section{WATER SUPPLIERS IN SOUTH KINGSTOWN}

Although this plan will apply most directly to public water suppliers and the respective wellhead protection areas, two other groups in the town merit attention. These are the private homeowners who draw potable water from private wells, and the non-community water suppliers.

\section{A. Private Wells}

According to service population data obtained from each of the suppliers in March 1997, it is estimated that approximately 50 percent of residents in town depend on private wells for their water. The majority of homes served by private wells are located in the lesser developed areas of town, generally in regions that are zoned for one, two, and five-acre single family residences. Risks in such locations are primarily confined to contamination from failing septic systems and to indiscriminate application of lawn chemicals. Although this plan was prepared for public, community water supplies, the Town's recommendations for safeguarding groundwater supplies, addressed in Section VII of this document, address issues pertinent to private wells.

\section{B. Non-Community Water Suppliers}

Incorporation of non-community water suppliers into this Wellhead Protection Management Plan is important for several reasons. First, non-community suppliers are numerous throughout town and serve a considerable number of individuals. Second, the primary recommendations resulting from the plan will encompass an educational component, and it is therefore highly important that all of the town suppliers be incorporated into such educational strategies. Last, the Town considers making suppliers aware of its own efforts a prerequisite to cooperation between suppliers, the Town and the state.

South Kingstown Planning Department staff contacted each of the suppliers and discussed with them issues they consider important and strategies that the suppliers are employing to protect the water supplies. Staff also discussed the requirements of the wellhead protection plan and ideas for future cooperation.

Profiles of each of the suppliers based on these discussions are in Table 2. 
Table 2: Non-Community Water Suppliers

\begin{tabular}{|c|c|c|}
\hline Water Supplier & Threats to Water Supply & $\begin{array}{c}\text { RIDOH Test Results } \\
1994-1996 \\
\end{array}$ \\
\hline Alternative Food Coop* & Route 138 & No results above MCL \\
\hline American Power Conversion* & Industrial waste & 5/94 Nitrate above MCL \\
\hline & Route 138 & $\begin{array}{l}10 / 94 \text { Positive result for coliform } \\
\text { bacteria }\end{array}$ \\
\hline Camp Fuller (YMCA) & & 5/95 Coliform bacteria \\
\hline Camp Hoffman (Girl Scouts) & & N/A \\
\hline Card's Camp & $\begin{array}{l}\text { Past cesspool use; replaced by } \\
\text { "honeycarts" and off-site disposal }\end{array}$ & No results above $\mathrm{MCL}$ \\
\hline $\begin{array}{l}\text { Carriage House Inn / } \\
\text { Champions Restaurant }\end{array}$ & Route 1 & 4/96 Nitrate approaching MCL \\
\hline DEM Fish and Wildlife & & N/A \\
\hline Holiday Inn & Route 1 & N/A \\
\hline Laurel Lane Golf Course & $\begin{array}{l}\text { Fertilizers/pesticides used in green } \\
\text { maintenance }\end{array}$ & No results above MCL \\
\hline Station House Restaurant* & Route 138 & N/A \\
\hline URI Liberty Lane & & N/A \\
\hline Worden Pond Camp & & N/A \\
\hline
\end{tabular}

In accordance with the Safe Drinking Water Act of 1974 and the 1986 amendments, the Rhode Island Department of Health (RIDOH) tests all community and non-community water supplies and conducts routine inspections of wells and supply lines. Test results from 1994 through May 1996 are reported in column three of Table 2. DOH tests for volatile organic compounds (VOCs), Synthetic Organic Compounds (SOCs), nitrate, and sodium. Results for each parameter are measured against federally established guidelines referred to as "Maximum Contaminant Levels" (MCL). Only results near or above the MCL are reported.

In addition to testing water supplies, RIDOH conducts inspections of the supplier wells and the distribution system. As example of the thoroughness of these inspections, the Planning Department acquired inspection results for the wells located at the Holiday Inn. The inspection resulted in a list of nineteen items requiring attention. Items noted included loose well covers, rusted bolts, and exposed pump wires. Holiday Inn complied with all the items within 60 days.

As indicated through the test results, the non-community suppliers in South Kingstown provide safe drinking water. The role of the Town in maintaining potability of these supplies is twofold: The Town must foster land-use policies designed to protect groundwater reserves in these areas, and must increase educational outreach to suppliers and the individuals they serve. Both components are addressed in the recommendations section of this plan.

\section{Public Water for Non-Community Suppliers}

The West Kingston Industrial Area has received public sewer and water as a means of maintaining groundwater quality in this area of town. The Town decided to undertake these improvements as a means of protecting the groundwater reserves in the area.

Several of the non-community suppliers located in this area received public water through the Kingston Water District in December 1996 and January 1997. These suppliers are American Power Conversion, the Alternative Food Coop, and Station House Restaurant. As illustrated in Table 2, not one of these three suppliers has experienced severe water contamination. 


\section{Community Water Suppliers}

Of the approximate 26,000 residents in South Kingstown, it is estimated that just over 50 percent obtain their potable water from one of the four community water systems. This section provides an overview of each suppliers' system and service area.

Table 3: South Kingstown Community Water Suppliers

\begin{tabular}{llccc}
\hline \multicolumn{1}{c}{ Water Supplier } & Supply Source & Number of Wells & $\begin{array}{c}\text { Annual Withdrawal } \\
(M G) 1992\end{array}$ & $\begin{array}{c}\text { Annual Withdrawal } \\
(\text { MG) 2010 }\end{array}$ \\
\hline \hline Allen's Health Center & Chipuxet & 2 & N/A & N/A \\
Kingston Water & Chipuxet & 2 & 124.2 & 188.1 \\
South Shore & Factory Pond & 2 & 85.0 & 83.8 \\
& Recharge Area & & & \\
United Water & Mink Brook & 6 & 1026.9 & 1303.0 \\
URI & Chipuxet & 3 & N/A & N/A \\
\hline
\end{tabular}

Source: Water Supply Management Plans

\section{Allen's Nursing Home}

Allen's Nursing Home is defined as a community water supplier because the facility serves approximately 100 residents on a year-round basis. The center has two covered wells, one shallow and one which was drilled. Located on Route 2, stormwater runoff from the highway poses a threat to the wells. Representatives from the facility also identified impacts from future residential development in this rural area as a considerable risk to water quality.

\section{Kingston Water District}

As indicated in Table 3, the Kingston Water District (KWD) obtains its water supply from the Chipuxet Aquifer. The two gravel packed wells serviced 672 connections in 1992, the majority of which (641, or 95 percent) provided water to private residences. In addition to residences, Kingston Water supplies numerous commercial establishments, governmental facilities, and the URI East Farm aquaculture facility with potable water. Total population served in 1992 was 2,260 individuals. Storage for KWD is provided by two elevated storage tanks located on Route 138 and Chestnut Hill Road with storage capacities of 100,000 and 500,000 gallons. Map 3 indicates well locations for the District.

Between 1982 and 1992 Kingston Water withdrew an average of 110 million gallons of water per year from both wells. Withdrawal rates peaked in 1991 at 132 million gallons. Five year estimates project a future demand of 115 million gallons and a twenty year demand of approximately 200 million gallons per year.

Town of South Kingstown South Shore Wells

The Town of South Kingstown South Shore Well System located near Factory Pond, serves the southern area of town including Matunuck, East Matunuck, Snug Harbor, Green Hill, and Ocean Ridge. According to figures from October 1993, the South Shore system supplies water to approximately 2,100 connections with a total service population of 3,200 individuals.

The wells draws solely from the aquifer recharge area. As such, the South Shore system does not need to meet criteria for Surface Water Treatment Rule as regulated by 1986 amendments to the Safe Drinking Water Act.

Most of the South Shore connections are for residential uses with only six percent of water consumed annually going to the twenty-nine commercial connections in this area, as indicated in Table 4.

Average annual consumption by South Shore customers between 1988 and 1992 was 78 million gallons per year (MG/yr), with the greatest increase in consumption occurring in 1992 with 
$85 \mathrm{MG} / \mathrm{yr}$ consumed. Future projections to the year 2012, using various standards of analysis, estimate annual use to range from a low of $76.5 \mathrm{MG} / \mathrm{yr}$, based on existing demand to $83.8 \mathrm{MG} / \mathrm{yr}$, which was computed using average historical growth as a basis. Using historical town population growth as an indicator of future demand, the projection was $78.9 \mathrm{MG} / \mathrm{yr}$ consumed. All future projections incorporate a future estimated 10 percent reduction in demand resulting from conservation methods. On several peak summer days each year the South Shore system nears design capacity.

The South Shore system consists of two gravel packed wells located 65 and 85 feet south of Factory Pond (see Map 4). Although the true recharge area for the wells has not been determined, RIDEM delineated wellhead protection area encompasses 1,994 acres around the wells. Storage of the potable supply is provided by two elevated storage tanks each with 400,000 gallons capacity. The tanks are located at Mautucket Road, near the wells, and on Succotash Road in the eastern part of the distribution system.

\section{United Water Rhode Island}

The wells operated by United Water Rhode Island (formerly Wakefield Water) overlay the Mink Brook Aquifer in the center of town. The company operates six gravel-packed wells at the Tuckertown and Howland wellfields. The wellfields are within 3,500 feet of each other, as indicated in Map 5.

United Water (UWRI) provides potable water to approximately 6,500 accounts in South Kingstown, Narragansett, and the Point Judith community. Total service population in 1992 was 16,700 individuals. Between 1982 and 1992, 1,600 new connections were established resulting in a service population increase of 5,200. As illustrated in Table 3, projected future populations to be served, calculated in accordance with the population projections prepared for the Towns' Comprehensive Plans, are 17,600 and 21,600 for five and twenty year periods, respectively.

Total system withdrawal rate capacity for all six wells 7.3 MGD. According to the UWRI Water Supply Management Plan, during calendar year 1992, UWRI customers consumed a total of $1,026.86$ million gallons of water. This corresponded to an average daily demand of 2.8 million gallons of water (UWRI Management Plan).

University of Rhode Island

The URI well system consists of three gravel-packed wells that draw from the Chipuxet Aquifer. The wellfield is located east of Thirty Acre Pond and the Chipuxet River. The Kingston Campus system serviced approximately 15,500 persons annually since 1992. Included in this number are the Peckham Farm facilities, Graduate Village housing area and two private residences located on Plains Road.

In addition to the wells, facilities include a one million gallon elevated storage tank located in the northwestern area of campus off Flagg Road. Well 4 serves as the primary source of potable water and wells 2 and 3 serve as back up. Distribution is provided via an underground pipe system.

Table 4: Connections Serviced by Water Suppliers

\begin{tabular}{ccccc}
\hline Type of Connection (in percent) & KWD & South Shore & United & URI \\
\hline \hline Residential & 47.1 & 94.0 & 51.7 & 100.0 \\
Commercial & 3.5 & 6.0 & 17.7 & 0.0 \\
Industrial & 0.0 & 0.0 & 3.0 & 0.0 \\
Government & 1.6 & 0.0 & 27.6 & 0.0 \\
Aquaculture & 44.5 & 0.0 & 0.0 & 0.0 \\
Other & 4.6 & 0.0 & 0.0 & 0.0 \\
\hline Total & 100.0 & 100.0 & 100.0 & 100.0 \\
\hline
\end{tabular}

Source: Water Supply Management Plans 
As indicated in Table 4, most service connections are to residential units, notwithstanding the high percentage of supply provided to URI's aquaculture facility, a research and teaching laboratory housing 40,000 trout and salmon, at East Farm by Kingston Water District.

UWRI services the entire Wakefield area of South Kingstown and supplies a significant portion of Narragansett's water supply. This explains the considerable percentage of water provided to commercial and governmental uses. 

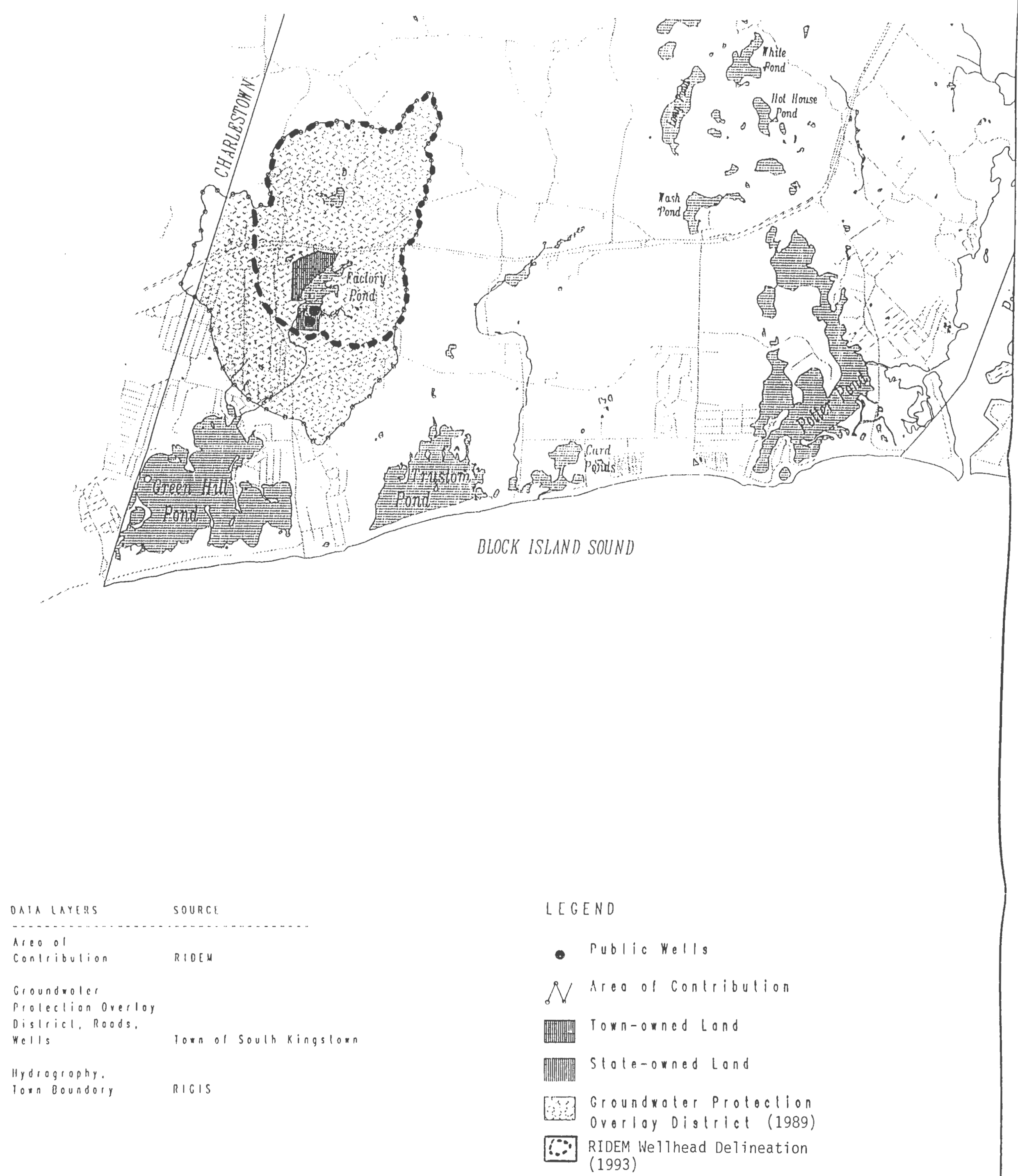


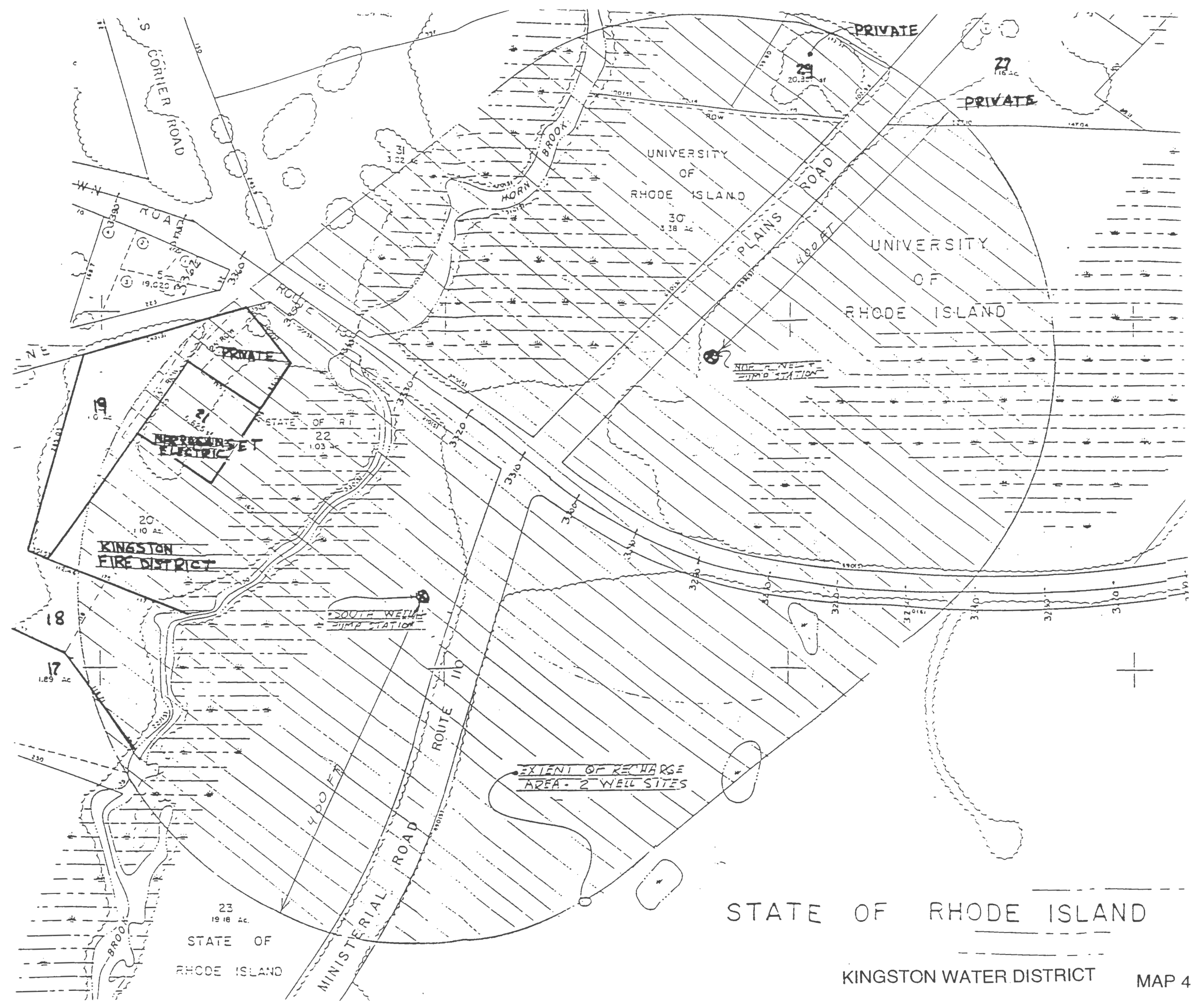




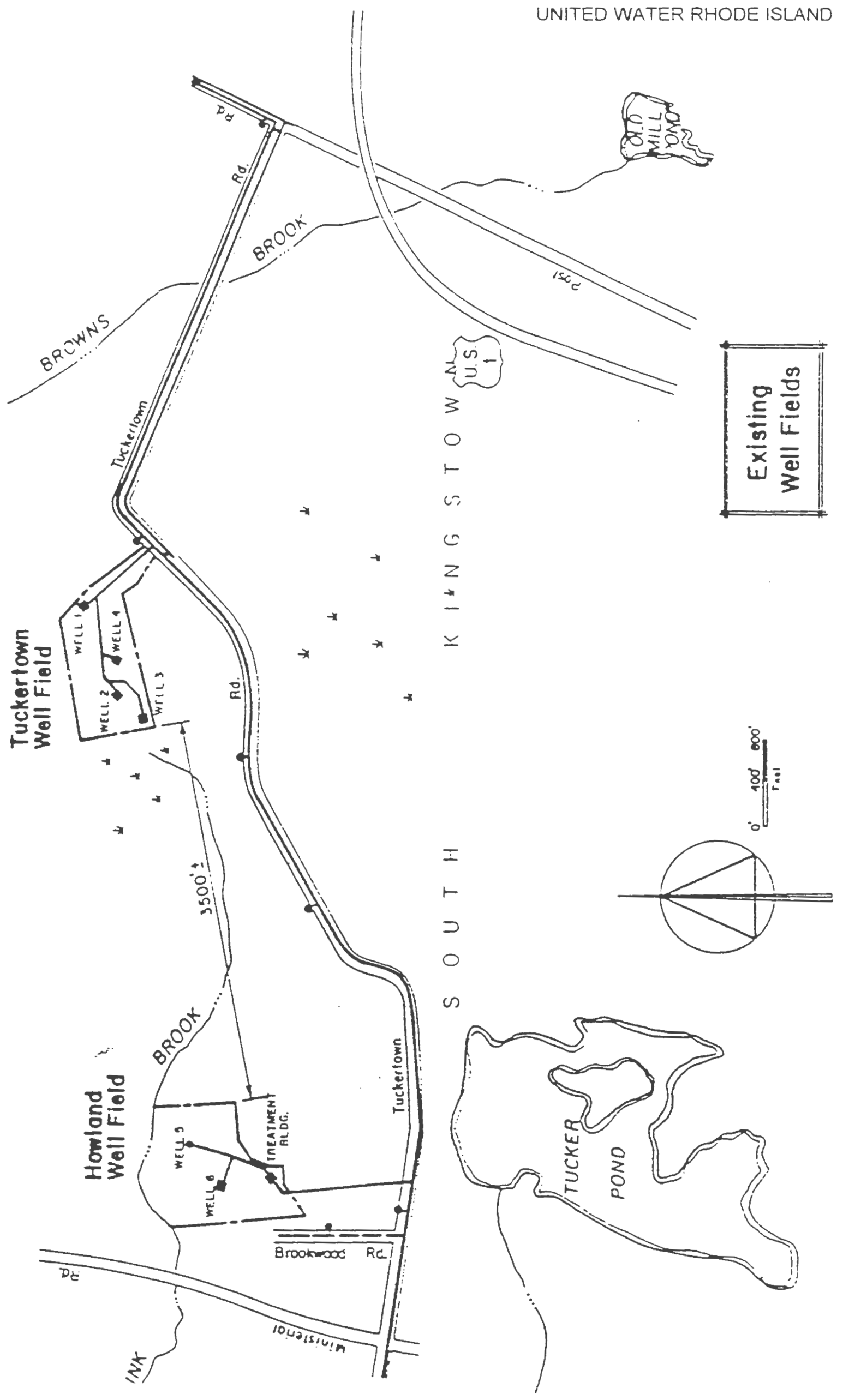

MAP 5 


\section{WATER QUALITY TESTING}

As discussed, the Rhode Island Department of Health (DOH) is the entity charged with monitoring and testing the water supplies for all public wells in the state. Their efforts in South Kingstown can be characterized as falling into three primary categories: surface water testing requirements; testing of supplier wells by $\mathrm{DOH}$ staff; and self-testing by suppliers with results submitted to and reviewed by $\mathrm{DOH}$ to ensure compliance.

\section{A. Surface Water Infiltration}

The Safe Drinking Water Act (SDWA) of 1974 and the 1986 amendments established guidelines that oversee the treatment, monitoring, and reporting of water supplies by major suppliers. The primary monitoring regulation within the SDWA is the Surface Water Treatment Rule (SWTR). This requires suppliers to report if the source supply is strictly from an aquifer ("Group 1" designation), or if the source is under the influence of surface water. Kingston Water District, the URI system and the South Shore system are exempt from SWTR; however, United Water wells number 2 and 3 both experience surface water infiltration into the water supply. The company was therefore required to complete two rounds of micro particulate analysis (MPA). Following completion of the tests and DOH review of the MPA results, the company was informed of being in compliance with the regulation.

\section{B. Rhode Island Department of Health Testing}

The Department of Health tests water supply systems in the state for the parameters as outlined in Table 5. The required frequency of each test is also indicated. Samples are drawn by DOH staff and tested at DOH labs.

Table 5: Department of Health Water Testing Requirements

\begin{tabular}{ll}
\hline Parameter & Testing Requirement \\
\hline \hline Asbestos & Once every ninth year \\
Nitrates & Quarterly for 1 year; reduce to annually \\
Nitrites & One one-time sample \\
Pesticides/SOCs & Quarterly every 3 years; reduce to twice every third year. \\
Selected Inorganics & Annually \\
Unregulated Organics & Quarterly every 3 years \\
Volatile Organic Compounds (VOCs) & Quarterly for 1 year; then annually; then reduce to every 3 years \\
\hline Source: Town of South Kingstown Utilities Department Management Plan
\end{tabular}

The following parameters were tested by the Department of Health at supplier wells during the twelve months prior to August 1995: 
Table 6: Parameters Tested at Community Supplier Wells

\begin{tabular}{|c|c|c|c|c|}
\hline Parameter Tested & Kingston Water & South Kingstown & United Water & $U R I$ \\
\hline Antimony & $\checkmark$ & $\checkmark$ & & \\
\hline Arsenic & $\checkmark$ & $\checkmark$ & $\checkmark$ & $\checkmark$ \\
\hline Asbestos & & & & $\checkmark$ \\
\hline Carbamates & $\checkmark$ & $\checkmark$ & $\checkmark$ & $\checkmark$ \\
\hline Coliform Bacteria & 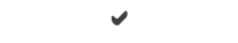 & $\checkmark$ & • & $\checkmark$ \\
\hline EDP/DBCP & $\checkmark$ & $\checkmark$ & $\checkmark$ & $\checkmark$ \\
\hline Endothall & - & $\checkmark$ & $\checkmark$ & $\checkmark$ \\
\hline Herbicides & $\checkmark$ & $\checkmark$ & $\checkmark$ & $\checkmark$ \\
\hline Nickel & & & $\checkmark$ & \\
\hline Nitrates & $\checkmark$ & $\checkmark$ & & $\checkmark$ \\
\hline Pesticides/PCB's & $\checkmark$ & $\checkmark$ & $\checkmark$ & $\checkmark$ \\
\hline Sodium & $\checkmark$ & & $\checkmark$ & r \\
\hline Thallium & $\checkmark$ & $\checkmark$ & & \\
\hline Trihalomethanes & & & $\checkmark$ & \\
\hline VOCs & 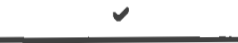 & 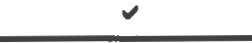 & 2 & 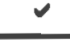 \\
\hline
\end{tabular}

Not all wells are tested for the same parameters. According to staff at the $\mathrm{DOH}$, this is due to locational differences and variations in water composition. This explains the apparent discrepancy among the parameters listed above.

In addition to these records obtained for the purposes of the plan, DEM Division of Groundwater provided the Planning Department with a summary of DOH test results for volatile organic compounds (VOCs), synthetic organic compounds (SOCs), sodium, and nitrate for each of the community supplier wells. The results of the tests are listed in the table that follows.

\section{Table 7: Detected Contaminants}

\begin{tabular}{ll}
\hline Supplier & Detected Contaminant \\
\hline \hline Kingston Water & $\begin{array}{l}\text { nitrate (a nitrogen compound derived from fertilizers and animal/human wastes) } \\
\text { aldicarb sulfoxide (by-product of the pesticide aldicarb) } \\
\text { aldicarb sulfone (by-product of aldicarb) } \\
\text { di (2-ethylhexyl) adipate (an industrial chemical and plasticizer) } \\
\text { di (2-ethylhexyl) phthalate (an industrial chemical and plasticizer) }\end{array}$ \\
\hline South Shore & $\begin{array}{l}\text { di (2-ethylhexyl) adipate } \\
\text { di (2-ethylhexyl) phthalate }\end{array}$ \\
\hline United Water & $\begin{array}{l}\text { nitrate } \\
\text { metolachlor (an herbicide) } \\
\text { aldicarb sulfoxide } \\
\text { aldicarb sulfone }\end{array}$ \\
\hline URI & $\begin{array}{l}\text { benzene (a natural component of crude oil and gasoline) } \\
\text { coliform bacteria } \\
\text { dalapon } \\
\text { metalochlor }\end{array}$ \\
\hline Source: RIDOH Records, provided via DOH and DEM Groundwater Division
\end{tabular}

The test results indicate that the community water suppliers in town generally have very high water quality, with only limited indications of contamination.

In response to positive test results, DOH staff follow a general procedure for mitigation. Upon receipt of one positive test result, $\mathrm{DOH}$ will re-test the well for confirmation. If the second test is negative, no further procedure is necessary. If the test provides a positive result, $\mathrm{DOH}$ will 
require any or all of the following: testing of all supplier wells, disinfection, repairs to the system, or closure of the subject well.

\section{Testing by Suppliers}

Suppliers are responsible for conducting their own tests of the water supply for copper, lead, and fecal coliform bacteria on a monthly basis. Copper and lead are both early morning draws, necessitating supplier-prepared samples.

Coliform bacteria tests are drawn by suppliers because of the number of samples required monthly. DOH regulations base sample requirements on the total population served by the supplier. Community suppliers in South Kingstown perform samples as shown in Table 8.

Table 8: Testing Requirements for Coliform Bacteria

\begin{tabular}{lcc}
\hline \multicolumn{1}{c}{ Supplier } & Service Population & Tests Monthly \\
\hline \hline Kingston Water District & 2,700 & 3 \\
South Shore System & 7,300 & 3 \\
United Water Company & 16,700 & 44 \\
URI & 15,500 & 16 \\
\hline Source: Water Suppliers &
\end{tabular}

Following collection of a water sample to be used for testing purposes, suppliers submit the samples to a laboratory that is either operated by the Department of Health or to a DOH certified lab. In addition to the fecal coliform draws, suppliers also collect samples for copper and lead because both require early morning collection. Samples are forwarded to an appropriate lab for analysis. 


\section{THREATS TO GROUNDWATER QUALITY}

In general, the groundwater in South Kingstown is of high quality, as indicated through the discussion in Section IV. Yet, because 100 percent of the water supply for South Kingstown residents is obtained from local groundwater reserves and easily polluted by local activities, it is of utmost importance that local interests recognize potential sources of pollution.

Sources of groundwater contamination can be defined as point source and non-point source pollution. Point source pollution is defined as contamination originating from a specific point on the landscape, such as a discharge pipe from a factory. Non-point source pollution originates from no single source and includes stormwater runoff, leaking underground storage tanks, and agricultural fertilizers and pesticides. In South Kingstown the majority of potential sources of contamination are non-point sources.

Following is an overview of some of the sources of groundwater contamination unique to South Kingstown. As will be discussed, there are many parties in town that seek mitigation of groundwater contamination from these sources. This includes State agencies, various departments within the Town, the individual water suppliers, and residents and business owners in the community.

\section{A. Inventory of Pollution Sites within Wellhead Protection Areas}

As required by State legislation as a component of DEM's Wellhead Protection Program, the Town and each of the water suppliers was required to prepare an inventory of potential sources of pollution within wellhead protection areas. South Kingstown Planning Department completed an inventory for the Town owned South Shore Well System, the URI wells, and each of the noncommunity supplier wells in Winter 1995. DEM approved the inventory list shortly thereafter.

The State guidance document for the inventory indicated which types of potential pollutants should be included in final submission. This included CERCLIS and Superfund Sites, underground storage tanks, automobile service stations, companies using any type of chemicals in processing, cemeteries, homes with outside storage tanks or unfinished basements, golf courses, and agriculturists.

The Town Planning Department conducted a detailed inventory using a variety of mechanisms. Through acquisition of State lists for CERCLIS sites, USTs, and unprotected home heating oil tanks, staff were able to identify the majority of sites. Town records were also reviewed and staff performed several windshield surveys to determine which sources were within the WHPA. In addition, Town representatives spoke with home and business owners located within the wellhead protection areas.

Following completion of the inventory, the Town determined each site's risk factor (LOWER, MODERATE, or HIGHER) using State guidelines. Lower risk threats to water quality include hotels, golf courses, restaurants, and sand and gravel operations. Sources of contamination that are of moderate risk are agricultural related activities, medical facilities, and research laboratories. Designated in the higher risk category are automotive repair facilities, dry cleaners, landfills, and photographic processors.

A risk assessment factor was assigned to each site based on the level of risk associated with the site and on proximity to the well. A complete listing of all sites inventoried by the Planning Department, each site's location, and a risk factor is included as Appendix A. 


\section{B. CERCLA}

Established by the United States Congress in 1980 and administered by the Environmental Protection Agency, the Comprehensive Environmental Response, Compensation, and Liability Act (CERCLA) addresses site remediation for more than 40,000 hazardous waste sites nationwide.

There are a total of seventeen CERCLA designated sites in South Kingstown. Seven of these sites are active, meaning that site investigation or remediation is underway, and ten sites are designated as archived. Archived sites are those sites for which the EPA has completed a site evaluation and determined that no remediation is necessary at this time (No Further Remedial Action Planned, or NFRAP) or that another authority will assume responsibility. All of the archived sites in South Kingstown are NFRAP and not one of the ten lie within a wellhead protection area.

Two active sites overlay the Chipuxet Aquifer recharge area. They are the West Kingstown/URI Disposal Area on Plains Road and the Photek Inc. property on Liberty Lane in West Kingston. Site assessment for the West Kingston Disposal Area began in 1988 and has included both the EPA and DEM review and analysis. This site is one of twelve sites state-wide placed on the National Priorities List (NPL). Ranking on the NPL means that remediation is required and that further steps will be taken. According to the EPA, only a small percentage of hazardous wastes sites are placed on the NPL. Those currently classified as national priorities are undergoing remediation.

The Photek, Inc. property was used for disposal of mercury wastes from operations at the company during the 1960s. Site investigations and evaluations have been underway since 1980 by several State agencies. In November 1996 DEM Division of Site Remediation released a final evaluation of the site entitled Final Expanded Site Inspection Report for Photek, Inc. Property. Data presented include findings of discrete mercury disposal locations, low concentrations of fuelrelated VOCs, and mercury vapor. The site is currently unoccupied but is accessible to the public.

DEM reports that approximately 34,000 people live within four miles of the site and approximately 90 percent of these residents are served by groundwater supply sources located within four miles of the site. Map 6 displays the Photek site and wellhead protection areas within a four mile radius.

At the time of the final site inspection, a private environmental consulting firm was further characterizing the extent of contamination from Photek operations in preparation for planned remedial activities by DEM. 


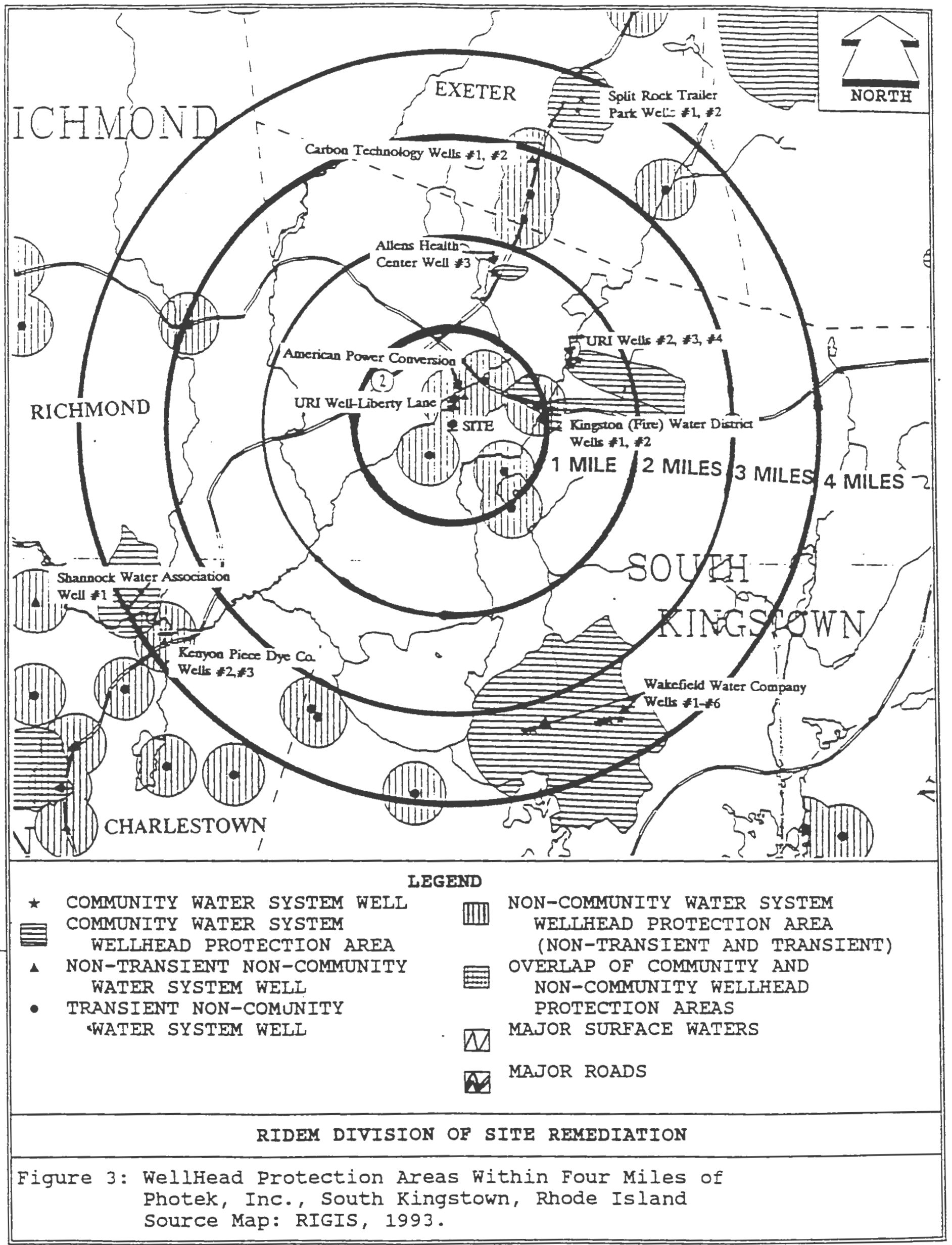




\section{Highway Runoff}

Roadways contribute a wide range of pollutants including heavy metals, bacteria, hydrocarbons, and salt. The majority of heavy metal load is initially dispersed as airborne pollution before it settles to the land surface. Upon settling, metals can penetrate surface waters and soils and eventually enter groundwater supplies.

Runoff is a concern for South Kingstown groundwater supplies because portions of Routes 1,2 , and 138 all overlay, or are in close proximity to, aquifer recharge areas. Each also carries a significant number of vehicles. Traffic counts obtained through the Rhode Island Department of Transportation (RIDOT) provide a means of assessing traffic volumes and the likelihood of substantial pollution resulting from increased traffic flow. Severe increases would clearly indicate that the Town adopt strategies to mitigate the harmful secondary effects. RIDOT traffic counts for points on each of the main thoroughfares in town are provided below:

Table 9: Two-way Traffic Counts for State Roads in South Kingstown

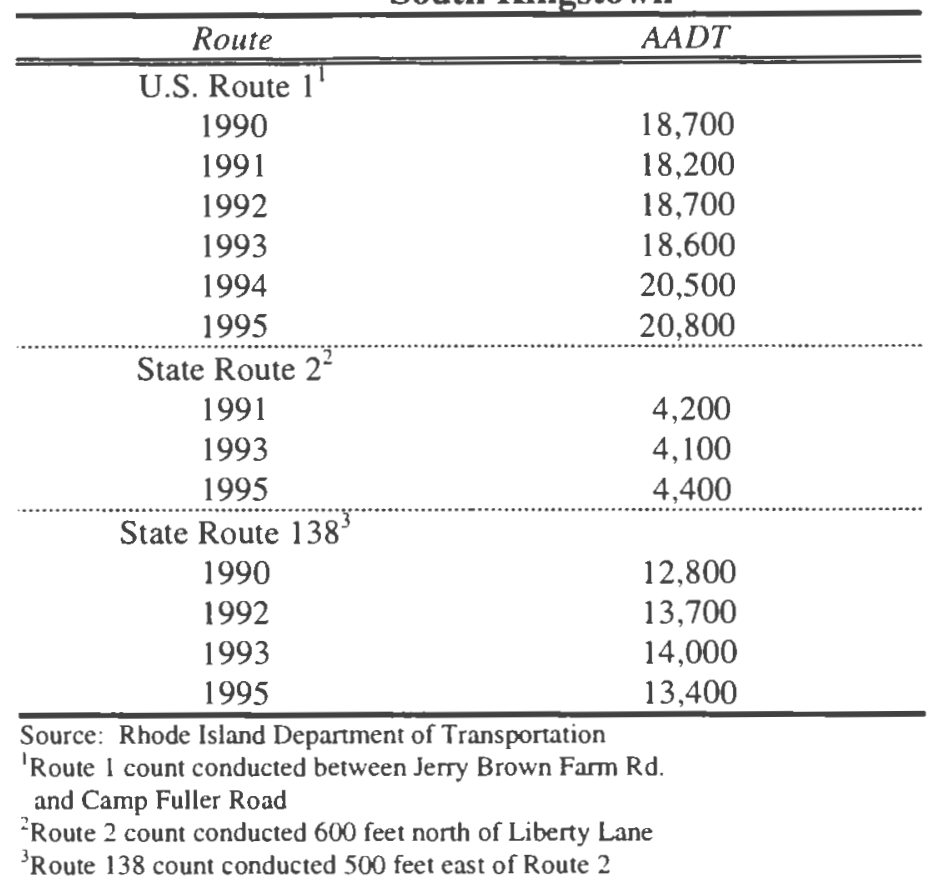

As indicated, traffic volumes on roads within recharge areas have not substantially increased since 1990. Despite a low increase in traffic volumes, the Town and the Department of Transportation are cooperating in the development and installation of a stormwater management system on that portion of Route 1 located north of Factory Pond and the public supply wells. The expected completion date is Fall 1997.

A second concern for public water supplies in relation to highways is the road sand and salt applied during the winter months. High levels of sodium and chloride in sand applications can result in long-term hydrological changes. An increased salinity would have long-term effects that could potentially alter plant composition and negatively affect salt-sensitive species.

The Rhode Island Department of Transportation, in accordance with the state's "black pavement policy," (i.e. snow clearance and sand application following winter storms to clear state roads of all snow and ice) and the South Kingstown Public Works Department apply a mixture of sand and salt to South Kingstown's roads during the winter months. Although application rates vary 
from year to year, depending upon the severity of winter storms, hundreds of tons of a sand and salt mixture is applied. Table 10 indicates the tons of salt applied to local roads by the Town during four winter seasons. The Department of Transportation does not record sand applications to roads by town and the data therefore do not include State owned roads.

Table 10: Sand and Salt Applications on Local Roads

\begin{tabular}{cc}
\hline Year & Salt Applied (in tons) \\
\hline \hline 1996 & $1,047.08$ \\
1995 & 416.79 \\
1994 & 1403.89 \\
1993 & 953.32 \\
\hline
\end{tabular}

Source: Town of South Kingstown Department of Public Works

\section{Highway Spills}

As reported by the Local Emergency Planning Committee (LEPC), Routes 1, 2, 108, and 138 are transport routes for many chemicals and hazardous materials. As portions of the roads overlay groundwater aquifers, concern of contamination to local groundwater resources is legitimate. Chemicals are not a considerable threat in a controlled environment; however, any accidental release of chemicals would present a serious threat to local water supplies.

State-mandated emergency response plans for water suppliers and the Town's own plan represent a proactive response to potential spill. All plans provide a management framework and response strategies in the event of a spill.

A more detailed discussion of the Town's emergency response plan is contained in Section VI: Strategies for Wellhead Protection.

\section{E. Individual Sewage Disposal Systems}

More commonly referred to as septic systems, individual sewage disposal systems (ISDS) are on-site household waste treatment facilities comprised of a septic tank and a leaching field. Some treatment occurs in the tank, where solids and liquids separate. The majority of decomposition occurs in the leaching field as liquids are treated and released. Solid wastes in the tank usually require pumping out at a minimum of every three years. Systems should also be inspected annually. Pumping and routine maintenance help insure that wastes do not leak into the ground. There is no law to enforce such a schedule of maintenance.

According to the Comprehensive Plan, almost 60 percent of South Kingstown residences rely on septic systems for disposal of sewage. Additionally, many commercial and industrial sites in town also use septic disposal systems.

As indicated through the map indicating sewer service areas in town (Map 7), only the most centralized areas of town, Wakefield and Kingston, are sewered. All areas not indicated as sewered or sites of future sewer service are thus dependent upon ISDS or forerunners to ISDS, cesspools. Cesspools also allow for on-site treatment of waste but have no leaching field. DEM regulations passed in 1970 prohibited installation of cesspools in new construction, but many existing residences predate the law and therefore still depend on cesspools for disposal of household wastes.

Critical regions of South Kingstown are the South Shore and West Kingston areas where high concentrations of homes and businesses depend upon on-site waste disposal. This poses a considerable threat to groundwater reserves. During 1996, the West Kingston Industrial Area received sewer extensions and hookups. This is the most western portion of the area labeled as "Future Sewer Service" on Map 7. Hook-ups were completed during January 1997. 
Beginning in the 1970's, numerous wastewater studies of the coastal ponds areas of town identified surface water contamination as originating from private septic systems. Eutrophication of coastal ponds, resulting from large amounts of nitrogen from septic systems, is of primary concem for this pristine and fragile area.

Soils within the coastal areas are comprised of stratified drift deposits of predominantly sands and gravels. Relatively rapid percolation rates occur within the subsurface strata of these large grain size particles. Wastewater percolating at a rate of one inch in two minutes does not provide adequate time for attenuation of pollutants by soil particles. This can result in contamination of groundwater and surface water from pollutants such as fecal coliform bacteria. This is especially a problem within high density residential development where a minimum separation exists between septic systems and private wells.

Because of the high percolation rates in the sandy soils of the coastal area, contaminants affecting surface waters also affect the groundwater resources that service every residential structure in the area. Contamination from fecal coliform bacteria is a concern primarily for residences relying on private wells. 


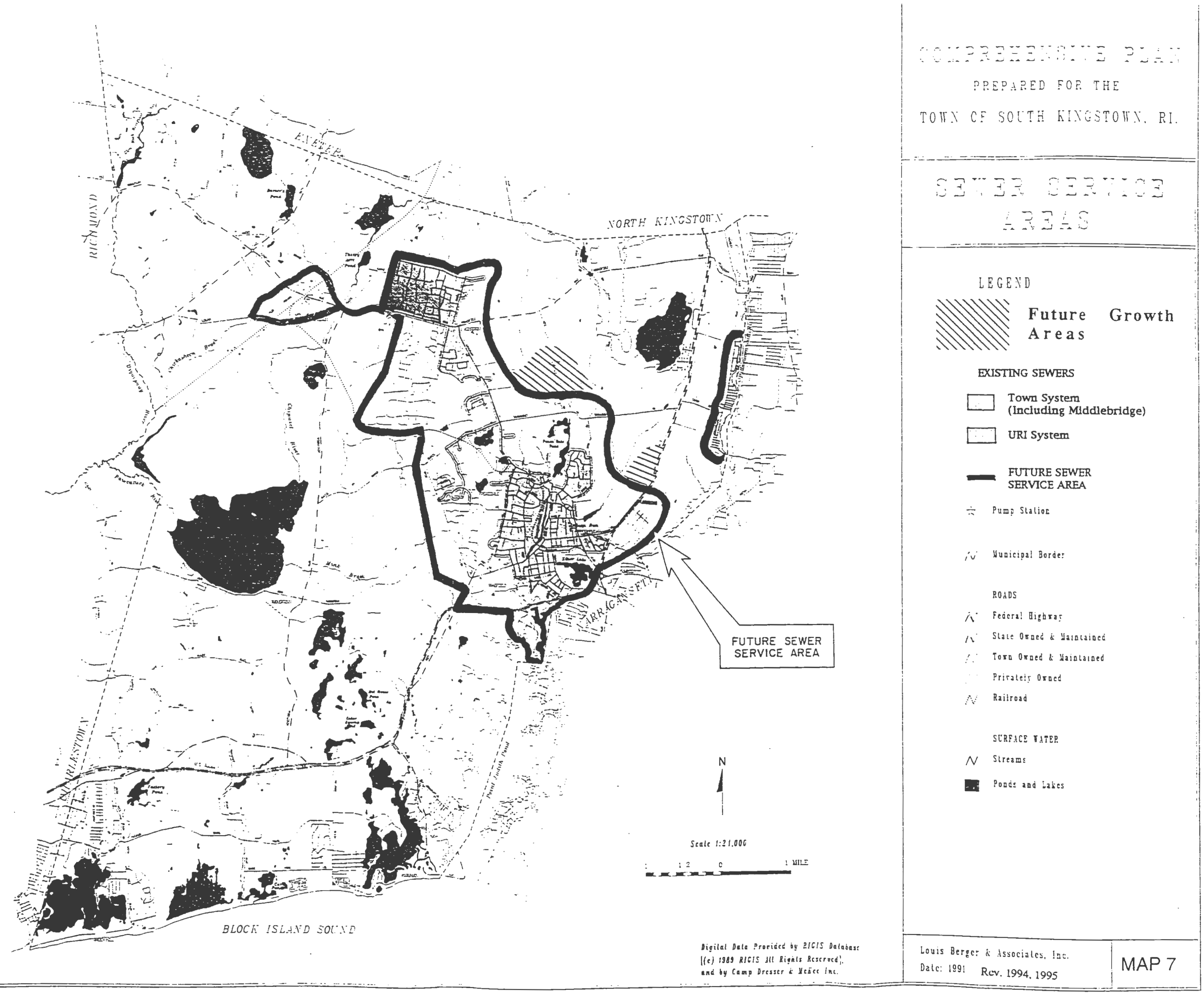




\section{F. Industrial Activities}

According to the Town assessor's records, there are nineteen (19) facilities involved in commercial or industrial manufacturing within the West Kingston Industrial Area. This region overlays the Chipuxet Aquifer and until January 1997 received neither sewer nor public water.

As indicated in the Wellhead Protection Inventory (Appendix A) many of these sites also have underground storage tanks (USTs), thereby compounding the risk to the public water supply. Many risks, excluding USTs, will be drastically reduced by provision of public sewer service to West Kingston.

According to the South Kingstown Director of Utilities, commercial and industrial users discharging into the public sewer system must meet local standards for pre-treatment. The South Kingstown Town Code identifies these standards as "national categorical pretreatment standards." Sewered industrial users must also submit a report indicating the nature and concentration of all pollutants discharged, as well as a statement of consistency with meeting the pretreatment standards.

Because the South Kingstown sewer system is a closed system, industrial discharges do not need to obtain a Rhode Island Pollution Discharge Elimination System (RIPDES) permit before discharging to the public system. The Towns of South Kingstown and Narragansett, who jointly operate the Publicly Owned Treatment Work in Narragansett, need a RIPDES permit before discharging into open waters.

\section{G. Mosquito Abatement}

Mosquitoes carrying the potentially fatal EEE virus were detected in Washington County in the Fall of 1996. State and town officials responded with an abatement program that included aerial spraying of Westerly and ground spraying in most Washington County communities. In addition deposition of larvacide briquettes in primary breeding areas was undertaken. The larvacide used contains the biological active ingredient BTI.

Although this recent limited spraying does not appear to present a significant threat to groundwater supplies, future detection of EEE carrying mosquitoes could result in a greater and more long term application of pesticides. Any extensive abatement program planned should include an assessment of potential adverse impacts to water resources.

Mosquito abatement plans that include spraying or larvacide application require DEM review and approval. Adulticide spraying within close proximity to surface water bodies is prohibited.

\section{H. Professional Farming Practices}

Historically farming has played a very important role in the growth of South Kingstown. Through the eighteenth and nineteenth centuries agriculture was the dominant economic activity and water of life for local residents. Although farming is much less visible today, agriculture continues to contribute significantly to the town. Farming provides a link to the town's history and development remains a desirable component of the local economy, and aids in open space conservation.

Professional farming does, however, present a risk to groundwater quality because of chemicals used to control pests, insects, and weeds, as well as use of nitrogenous fertilizers. In turn, excessive levels of nitrogen in drinking water supplies, originating from such sources, has been found to cause, or "blue-baby syndrome". More recent studies have identified some nitrogen compounds as carcinogens (Witten et al. 1995).

Although working farms have diminished state-wide, as of December 1995, 213 parcels in town were recorded as agricultural. This amounts to a total area of 6,882 acres. Predominant 
among agricultural parcels are those devoted to commercial vegetable farming, christmas tree farming and turf farming.

Studies completed by scientists in the Department of Natural Resources Science at the University of Rhode Island between the late 1980's and early 1990's found that manure-fertilized silage corn with and without cover crop introduces considerable levels of nitrate-nitrogen to groundwaters (Gold et al. 1990). Particularly high levels of nitrogen in water result from techniques associated with corn production. During two test years, the nitrate-nitrogen levels for corn production were in excess of the federal drinking water standards.

Practices associated with turf raising, a common crop among farmers in South Kingstown, also introduces nitrogen to groundwater supplies. Threats resulting from turf farming are less than is commonly perceived, and less than those associated with corn production or septic systems (Gold et al. 1990). Groundwater degradation stemming from agricultural processes can be minimized through proper fertilization and irrigation management techniques. Many professional turf farmers in the West Kingston area cooperate with the URI Cooperative Extension and the Southern Rhode Island Conservation District to achieve best management practices in turf farming (Sullivan 1996).

\section{Residential Lawncare}

The cumulative impact of improperly managed lawns, through overfertilization, contribute a severe amount of nitrate-nitrogen to groundwater supplies. This poses a risk to private wells located on a homeowner's parcel of property, and on nearby public supply wells.

According to DEM Division of Agriculture studies, homeowners' use of fertilizers account for 80 percent of fertilizers used in the state. The Division also found that homeowners and professional applicators use more than double the amount of fertilizers that commercial agriculturists apply (DEM Pesticide Management Plan 1996). In densely developed residential areas the negative impact of applications can accumulate thereby increasing the risk to groundwater supplies.

In addition to fertilizer use, a 1988 Division of Agriculture survey of 300 households statewide found that 49 percent of Rhode Island households apply pesticides to their property. Applications are made both by homeowners and by commercial applicators. By law, commercial applicators must receive training and certification in pesticide application. However, most homeowners do not have access to proper handling procedures for pesticide application, and therefore application by homeowners presents a considerable risk to groundwater systems (DEM Pesticide Management Plan 1996).

In South Kingstown many residential subdivisions with large, well-landscaped properties represent a considerable threat to groundwater supplies. Additionally, there is the potential of cumulative negative impacts resulting from increasing densities and continued application of lawn chemicals by homeowners. The recommendations section of this plan discusses strategies to mitigate effects of fertilizers and pesticides used with home lawncare.

\section{J. Underground Injection Control}

Underground Injection Control (UIC) is the subsurface discharge of industrial and commercial wastes. UICs inject wastes into the ground through a well, cesspool, septic system, pit, or holding pond.

UICs are regulated by DEM Groundwater Division with the Division's primary goal being protection of existing and future underground drinking sources from contamination. UICs function as waste disposal when sewer systems are unavailable or inadequate for specific waste treatment needs.

State and Federal guidelines divide underground injection control systems into five different classes. Rhode Island State regulations legally permit installation and operation of Class $\mathrm{V}$ wells 
only. These include storage and disposal devices such as ISDS, cesspools, air conditioning return flow wells, and aquifer replenishing-recharge wells.

According to DEM Office of Water Resources, there are eleven UIC wells in South Kingstown, five of which overlay a recharge area or lie within the boundaries of a wellhead protection area. The sites are included in Appendix A.

\section{K. Underground Storage Tanks}

According to various studies by the Environmental Protection Agency, there are an estimated 1.4 million underground storage tanks (USTs) containing gasoline nationwide. Many of these are made of steel with no protection against corrosion. Gasoline contamination, in turn, has been found to be one on the most common causes of groundwater contamination (USTs: A Guide for Local Officials 1988). Detection of leaks from USTs is very difficult and in many cases impossible until local groundwater sources show signs of contamination. All underground storage tanks must be registered with the Department of Environmental Management. The State the installation date, type of fuel contained, and the material of which tanks are comprised.

Based on data provided by DEM in 1994, there are approximately 190 registered and existing underground tanks in South Kingstown. Tank size ranges from 500 to 25,000 gallons. A very small percentage of these sites are located within any of the wellhead protection areas. Actual sites are included in the inventory (Appendix A). In addition to these existing tanks, more than 170 underground tanks have been removed from sites located throughout South Kingstown during the past decade.

The State also keeps record of leaking underground storage tanks (LUSTs). As of 1994, approximately 30 tanks in town had been identified as leaking. LUST sites in wellhead protection areas are also included in Appendix A.

Clean-up and remediation costs from leaking tanks can be prohibitive. Expenses run into the hundreds of thousands of dollars when costs such as tank removal, soil removal, well replacement, and testing are considered. Thus, central to mitigating the effects from underground storage tanks is their regulation, as discussed in Section VI under Town and State regulatory initiatives.

\section{The University of Rhode Island}

The University of Rhode Island is the State's largest research facility with labs for studies in engineering, chemistry, biology, and photography. In the inventory of potential sources of pollution, these sites were found to pose a considerable risk to the groundwater because of the materials used. In addition, many of the University buildings are older structures, and therefore have dated drainage and piping systems that do not meet current standards of construction.

In 1994, the Department of Environmental Management conducted an inventory of threats to groundwater located in and around the University. A total of twenty-four sites were included in the list, among them, underground storage tanks, a print shop, photo processing studio, and automobile storage facility. Since that time, however, thirteen USTs have been removed from the University grounds. According to information provide by the URI Department of Facilities and Operations, as of March 27, 1997 the removed tanks include the following locations: 
Removed Underground Fuel Oil Tanks

1.Agronomy Laboratory

2.Agronomy Greenhouse

3.Athletic Work Drying Shed

4.Dairy Facility

5.International House

6.Meade Field

7.URI Turf Farm

8.Thirty Acres

9.Food, Science, and Nutrition Facility

10.Animal Facility

11.Peckham Farm Incinerator

12. Faculty Apartments

13. Child Development Center

Additional underground storage tank locations are included as part of the inventory in Appendix A.

\section{Unprotected Fuel Tanks}

Tanks storing home heating oil and other fuels for residential use need to be protected from environmental elements in order to not rust and corrode when exposed to water and other elements. During the inventory phase for wellhead protection planning, South Kingstown investigated the occurrence of unprotected residential fuel tanks. Using DEM records as a basis of identification, twenty-three storage tanks were found to be either in an incomplete basement (dirt floors and walls) or outside of the residence and clearly unprotected from the elements. Breakdown by wellhead protection area is as follows:

Table 11: Residential Storage Tanks within WHPAs

\begin{tabular}{cc}
\hline Wellhead Area & Number of Exposed Tanks \\
\hline Holiday Inn & 2 \\
South Shore Wells & 13 \\
Card's Camp & 1 \\
Charlestown WHPA & 7 \\
\hline
\end{tabular}

Although a concern to local officials, regulating exposed tanks is difficult without legal authority to do so. Regulations governing new construction mandate that storage tanks located outdoors be protected or enclosed in a complete basement. For existing tanks, the Town needs to develop an educational strategy to inform homeowners with unprotected tanks of associated environmental risks.

\section{N. Future Growth Based on Current Zoning}

In order to best ascertain the potential for future threats to the groundwater reserves, the Planning Department prepared a build-out analysis for the groundwater protection areas based on current zoning regulations.

Base data were obtained through the Town's tax database for all developed and undeveloped parcels located within the groundwater protection district. Numbers of developed and undeveloped parcels within each zone were also identified. Not included in the analysis are those undeveloped properties that have no potential for development. Thus properties with the development rights purchased by DEM Agricultural Land Preservation Commission, the South Kingstown Land Trust, and the Audubon Society were eliminated. Additionally, properties owned 
by the State and the Town of South Kingstown were also not included. Properties currently classified under the Farm, Forest, and Open Space tax status were included, however, because the right to develop is not removed from such lands.

Following identification of potential properties, Planning Department Staff then performed a buildout scenario for the potential square footage of land to be used for commercial and industrial structures, the maximum number of residential structures and ensuing population expansion.

The following table displays the results of this buildout. Residential zones included R20, R30, R40, RR80, and RLD200 lots (one-half to five acre parcels). In 1976 and 1984, South Kingstown rezoned much of the land over the aquifers to two and five acre zoning, respectively. Existing lots, those "grandfathered in," remained at the smaller zone size, and build-out results reflect these variations in lot size. As evident in Table 12, commercial and industrial zoning exists only within the wellhead area overlying the Chipuxet aquifer. Parcels zoned for commercial development are almost completely developed, but there still exists considerable acreage yet undeveloped that could be used for manufacturing uses.

Table 12: Potential for Growth Based on Current Zoning within GPOD

\begin{tabular}{|c|c|c|c|}
\hline Zone & Chipuxel & Factory Pond & Mink Brook \\
\hline $\begin{array}{l}\text { Residential } \\
\text { Number of units } \\
\text { Population* }\end{array}$ & $\begin{array}{r}873 \\
2,296\end{array}$ & $\begin{array}{l}106 \\
279\end{array}$ & $\begin{array}{l}276 \\
726\end{array}$ \\
\hline $\begin{array}{l}\text { Commercial } \\
\text { Structures }\end{array}$ & 0.12 Acres & 0 & 0 \\
\hline $\begin{array}{r}\text { Manufacturing } \\
\text { Structures }\end{array}$ & 30.4 Acres & 0 & 0 \\
\hline
\end{tabular}

\section{O. Wells at Greatest Risk for Contamination}

Based on the inventory of threats to groundwater, the wells most at risk for contamination are those drawing from the Chipuxet Aquifer in the Kingston and West Kingston areas of town. This is true for the following reasons:

1. The interconnected nature of the aquifers in this area, all are part of the Pawcatuck Watershed, make this a fragile and penetrable system.

2. Although recently sewered, the industrial activities in West Kingston increase the likelihood of contamination of the reserves. This might be through routine operation of industries or a spill. Also, as indicated in the zoning buildout, the area overlaying the aquifer could potentially experience an increase of thirty-nine acres for manufacturing use.

3. More than twenty sites at The University of Rhode Island were identified as housing activities that could affect the quality of local groundwaters.

4. Route 138 carries significant volumes of traffic and hazardous materials. Road runoff and the possibility of chemical spills threaten local water supplies.

5. The areas outside of Kingston and West Kingston are not sewered, therefore requiring residences and other uses to rely on septic systems for household waste disposal.

6. Several agricultural parcels, such as commercial produce and turf farms employing pesticides and fertilizers in production, are also located in this region.

7. Residential growth in the area, up to 2,300 residents under existing zoning, increases the potential for groundwater contamination. Groundwater pollution stemming from septic systems and from residential use of lawncare products pose the greatest risks. 
These potential sources of contamination threaten no single well in the area. Rather, because of the region's hydrology, community suppliers, non-community suppliers, and private wells are all threatened. Included among these are Kingston Water District, the University system, Camp Hoffman, DEM Fish and Wildlife, and private wells located on residential parcels. The Town's recommendations for future actions (Section VII) will address needs concentrated in the West Kingston area in particular. 


\section{STRATEGIES FOR WELLHEAD PROTECTION}

Effective strategies for groundwater protection currently exist in South Kingstown. A variety of programs and regulations are in effect at the Federal, State and local levels. The following inventory and discussion is designed to acknowledge those programs already in place and to identify the key components of each that pertain to groundwater protection. As such, the inventory of existing strategies serves two purposes: It helped to identify weaknesses in groundwater legislation and programs and thus assisted staff in developing recommendations that will strengthen yet not duplicate current efforts.

As is the case with the Wellhead Protection Program, the Federal Government oftentimes takes the lead in developing legislative policy relating to groundwater protection. Congress has the authority to establish programs to be adopted by the fifty states. In turn, state governments transform federal policies into rules and regulations applicable both to state residents and to the municipal governments. State legislation can take the form of enabling legislation, which allows towns to adopt particular strategies, or mandated legislation, which requires local governments to conform to state standards.

\section{A. Federal Regulations}

Federal laws passed by the United States Congress during the past several decades have addressed the need to protect ground water. However, no single law protects groundwater supplies. Rather, a variety of laws contain components that can be applied to groundwater protection efforts.

The following section describes these federal laws and identified the key elements of each that aid in protecting water supplies. As shall become evident, some laws are preventive in nature, others are remedial. However, none are comprehensive.

Comprehensive Environmental Response, Compensation, and Liability Act (CERCLA) (more commonly referred to as "Superfund") 42 USC 96011980 Substantial modification by Superfund Amendment and Reauthorization Act of 1986 (SARA).

Purpose: To address health and environmental threats posed by abandoned hazardous waste sites.

Components relevant to groundwater protection:

1. Hazardous Substance Superfund - Through development of the a mechanism, Congressional writers hoped to establish monies for the cleanup of hazardous sites. The fund was formed to provide federal and state sharing of response costs. Additionally, responsible parties and past users of the site are responsible for cleanup costs.

2. Cleanup Standards - The legislation set norms to be followed in remedial action cleanups. This includes protection of local populations within cleanup strategies.

3. Emergency Planning and Community Right to Know SARA Title III 42 USC 11001 - This clause within the SARA Amendments of 1986 was enacted to raise public awareness regarding use of hazardous materials nationwide. The legislation requires each state form a state emergency response commission and this entity to, in turn, create local emergency planning committees (LEPC)for local districts. The Right-to-Know component of the law mandates owners and operators of facilities handling toxic chemicals to submit an inventory of such substances to government authorities.

Federal Insecticide, Fungicide, and Rodenticide Act 7 USC 136h 1947 substantial amendments in 1972 with the Federal Environmental Pesticide Control Act and the FIFRA amendments of 1975 , 1978,1980 , and 1988. 
Purpose - Regulates pesticides and prohibits the production or distribution of any pesticide not registered with the EPA or an EPA-approved facility. The law is administered primarily by states.

Components relevant to groundwater protection:

1. Registration process: The EPA classifies pesticides into categories of "general use" and "restricted use." The latter category requires special procedures to avoid health and environmental risks. This includes application by certified professionals only.

Federal Water Pollution Control Act (The Clean Water Act) 33 USC 125I 1972: Amended in 1977 and again in 1987 as the Water Quality Act.

Purpose: To restore and maintain the chemical, physical, and biological integrity of the Nation's waters.

Components relevant to groundwater protection:

1. National Pollution Discharge Elimination System (NPDES) -- Permitting procedure to control industrial pollution discharge into public waterways. Permits issued on the condition that any discharge will meet statutory standards. The Federal law encourages states to adopt own permitting programs, provided that standards are as strict as CWA requirements. 1987 Amendments to the Act increased the likelihood of state adoption of permitting programs. Rhode Island Pollution Discharge Elimination (RIPDES) program was adopted in 19.

2. Nonpoint Source Management Program -- Requires states to prepare a report identifying significant sources of nonpoint pollution for a given body of water and the likelihood of compliance with federal guidelines based on nonpoint source pollution. Each state must obtain EPA approval of a management program designed to address and control nonpoint sources as well as best management practices to reduce pollution.

3. Publicly Owned Treatment Works (POTWs) -- Authorization for EPA to disburse grant monies to fund construction of public sewage plants. The legislation also empowers the EPA to determine suitability of an area for a POTW and to set effluent limitations.

Hazardous Materials Transportation Act 49 USC 1801

Purpose: To regulate the transportation of hazardous materials. The law preempts inconsistent state law.

Components relevant to groundwater protection:

1. Handling Requirements - The law sets standards for the minimum number of personnel required to handle hazardous materials. Also establishes minimum training and qualifications that such handlers must possess.

National Environmental Policy Act (NEPA) 42 USC 43211969

Purpose: To require federal agencies to consider environmental impacts of activities.

Components relevant to groundwater protection:

1. Environmental Impact Statement (EIS) - Federal agencies must prepare an EIS for any action with the potential of significantly altering the environment. Necessary components are a detailed description of effects from the proposed activity and alternative courses to prevent such effects. 
Resource Conservation and Recovery Act (RCRA) 42 USC 6901 1976, amended in 1984 with the Hazardous and Solid Waste Amendments (HSWA).

Purpose: To protect public health and the environment from problems associated with hazardous and solid wastes including treatment, storage, and disposal.

Components relevant to groundwater protection:

1. Hazardous Waste Management -- The law authorizes the EPA to impose health and safety standards on generators, transporters and disposal operators of hazardous wastes. EPA also established criteria for the listing of any material as "hazardous." As of 1991, 700 wastes were listed as hazardous.

2. Underground Storage Tanks -- The 1984 amendments included provisions for the regulation of USTs. Provisions include registration of USTs containing hazardous substances, leak prevention and detection measures, and remediative actions for leaking USTs. Exempt from RCRA are USTs containing fuel for on-site residential use or farm use.

Safe Drinking Water Act (SDWA) 42 USC 300f - 330j - 11 1974; amended in 1986

Purpose: To protect the quality of the Nation's drinking water supplies.

Components relevant to groundwater protection:

1. Maximum Contaminant Levels (MCLs) -- Requirement that the EPA establish contaminant levels not to be exceeded in public water supplies. Each MCLG must be fixed at a level that is known to produce no adverse health effects. Prior to the amendments in 1986, 22 of 700 known contaminants were regulated in this manner. The amendments added an additional 61 contaminants to the regulated list. This provision applies only to public water suppliers. There is no monitoring mechanism for residences or businesses drawing from private wells.

2. Underground Injection Control regulation (UIC) -- EPA must establish criteria for development and regulation of state UIC programs. Minimum state requirements and permitting system criteria are included in the law. States with EPA approved programs must act on known violations within thirty days of receiving notice. If a state regulatory agency does not move to remediate known UIC violations, the Federal EPA may intervene.

3. Sole Source Aquifers (SSA) -- The SDWA provides specific provisions to protect SSAs, groundwater sources supplying the only viable means of potable water to an area. The Wood Pawcatuck Watershed was designate a Sole Source Aquifer by the EPA through such provision in the SDWA.

4. Wellhead Protection Program -- As discussed in the introductory section of this plan, the SDWA amendments in 1986 established the EPA as the entity responsible for creating criteria for state wellhead protection programs. The statute also authorizes federal assistance for program development and implementation.

Toxic Substances Control Act 15 USC 26011976

Purpose: Regulates the distribution of toxic substances in commerce.

Components relevant to groundwater protection:

1. Restrictive use and disposal procedures - The legislation enables the EPA to restrict disposal of certain toxic chemicals in order to protect the public health and safety. 
2. Reporting requirements - Manufacturers of chemicals must report specific information to the government which is to include a description of by-products and data on the environmental and health effects of each substance.

\section{B. State Regulations and Programs}

The State of Rhode Island, primarily through various divisions and offices within the Department of Environmental Management, has established a variety of programs to address groundwater issues at the local level. DEM is the primary entity charged with overseeing groundwater protection, primarily through the Divisions of Groundwater and ISDS, Agriculture, Waste Management, and Site Remediation. Another state agency with an essential role is the Department of Health.

As at the Federal level, many laws pertaining to groundwater have been passed, and a variety of programs designed to prevent groundwater pollution, in addition to the Wellhead Protection Program, exist. This section is intended to provide an overview of some of the programs at the State level that pertain most specifically to wellhead protection in South Kingstown. This is not intended to be a comprehensive discussion. Instead, it will provide local residents and officials with information on the many different ways that drinking water is being protected in Rhode Island.

\section{ISDS Permitting Regulations}

The rules regulating individual sewage disposal systems were most recently amended by DEM in 1992. DEM's guidelines establish minimum standards for location, design, construction, and maintenance of ISDS. Siting requirements address water table elevations, establishes minimum setbacks for coastal ponds, private wells, watersheds, and surface water reservoirs.

\section{Pesticide Control Act of 1976 (RIGL 23-25-1)}

The State of Rhode Island and DEM Division of Agriculture require all agricultural producers to keep two-year records of restricted pesticides used in production. Restricted pesticides are defined by Federal standards according to composition. No record of unrestricted pesticides is required according to state law. In order to purchase any restricted pesticides, a user must receive certification and a permit, both which require periodic renewal. Suppliers must also be certified.

Rhode Island General Law mandates that all regulation of pesticide, herbicide, and fertilizer use by commercial users will be monitored by DEM. The State is currently preparing $A$ Management Plan for the Protection of Ground Water from Pesticides and Nitrogenous Fertilizer. This will serve as a means of raising awareness among local farmers and can provide a framework for future herbicide, fertilizer, and pesticide monitoring.

In addition to State efforts, URI Cooperative Extension and the Agriculture Experiment Station are working in conjunction with local turf farmers to establish best management practices.

\section{Public Drinking Water Act}

Passed in 1987, the Public Drinking Water Act provides funding for water suppliers statewide to further protection efforts. No less than 55 percent of funds may be used for land purchases, a maximum of 10 percent may cover administrative expenses, and the remaining 35 percent of funds can be employed in other protection projects.

Funds are provided via a surcharge of several cents for every 100 gallons of water sold to retail and wholesale users of public water. The Rhode Island Water Resources Board, developed via this law, is responsible for administering the funds. 
In addition to financing secured through a surcharge, the 1987 legislation established a $\$ 10$ million grant fund to be used as matching funding for systems that exceed the 55 percent for land purchases.

According to the law, commercial agricultural producers are exempt from the charge provided that they have a conservation plan on file with the local Soil Conservation District.

\section{Rhode Island Water Pollution Act RIGL 46-12}

This act provides for the general protection of Rhode Island's waters, both surface and groundwaters. Specific provisions of the Act, which complies with the Clean Water Act and the Safe Drinking Water Act, include program development to prevent water pollution, permit issuance for pollution discharge, septic treatment oversight to ensure compliance with Federal pretreatment regulations, and establishment of water quality standards.

Elements of the law that relate directly to groundwater protection are the following. 46-12-25.1 Regulates well siting in proximity to solid waste disposal areas. Location of Wells or on-site drinking water supplies within 1,000 feet is by special permitting only.

46-12-28 Provisions for in-ground and surface disposal of industrial and commercial pollutants. Subsurface disposal units must comply with Federal requirements for underground injection control units as established in SDWA,

46-12-30 Established the UST replacement revolving loan fund administered by DEM. Provides funding for owners of residential and commercial property requiring UST replacement.

46-12-38 Established guidelines for UST tank testers.

\section{Rhode Island Groundwater Protection Act of 1985 RIGL 46-13.1}

This law was passed to protect the critical groundwater supplies in the state. The legislation provides for groundwater classification, mandated a DEM study of the groundwater reserves statewide, and the most recent amendments include Wellhead Protection (46-13.1-9).

\section{Underground Injection Control}

State laws regulating UICs were promulgated pursuant to the requirements in the RI Water Pollution Act and the state legislation that established the Department of Environmental Management (DEM). Rhode Island law prohibits Class I-IV wells and places restrictions on the Class $\mathrm{V}$ disposal wells. The legislation contained in the State laws establishes conditions for siting approval of UICs as well as tank registration requirements. DEM Division of Water Resources oversees the State UIC program.

\section{Underground Storage Tanks}

According to Rhode Island State Law Sections 23-9, 46-12, and 42-35, underground storage tanks are regulated by and must be registered with the Department of Environmental Management. DEM adopted its first comprehensive UST regulations in 1985, and since that time they have been revised to incorporate new federal requirements. The purpose of the State legislation is to prevent groundwater contamination that could result from leaking underground storage tanks.

Tanks exempt from these DEM regulations include:

- Storage tanks holding less than 1,100 gallons of No. 2 home heating oil for 1,2 or 3 family residential dwellings;

- USTs of 1,100 gallons or less storing No. 2 heating oil for farm or residential use;

- Tanks connected to floor drains serving 1,2, or 3 family residential units;

- USTs located on an impervious floor or base within an underground area that is not a basement or cellar; 
- Flow through process tanks;

- Propane or liquefied natural gas tanks.

Since adopting the regulations in 1985, DEM has developed records on approximately 12,000 USTs located at 3,000 facilities statewide.

A second purpose of the legislation is to serve as enabling legislation for Rhode Island communities wishing to pass local regulatory ordinances for USTs. Municipal laws must be at least as strict as existing State law. South Kingstown's GPOD Ordinance supplements these State standards by prohibiting all underground storage tanks from the overlay districts except tanks that store less than 300 gallons of home heating oil.

\section{Hazardous Waste Collection}

DEM Division of Waste Management had at one time coordinated annual hazardous waste collection days for state residents. The program has since been disbanded and area residents must now initiate proactive steps to properly dispose of hazardous materials. A household waste drop-off site is located at Fields Point in Providence.

Disposal of hazardous materials used in commercial establishments is by means of Stateapproved transporters to permitted hazardous waste facilities.

\section{Signage}

DEM Office of Water Resources and RIDOT are undertaking a pilot project for signage over wellhead protection areas. As part of the project, two signs will be placed on the north and southbound lanes of Route 1, near the South Shore well system. This will alert both local residents and visitors of the aquifer recharge area.

\section{Town Regulatory Measures}

A variety of strategies for wellhead protection at the local level have been identified. Common techniques center around regulatory measures such as overlay districts and subdivision regulations. Such strategies are oftentimes granted to local governments through adoption of laws at the federal and state levels, as is apparent in the overlap between state and local regulations.

Non-regulatory measures can involve such techniques as land donation, tax incentives, and public education. Such approaches to protection require municipalities to develop strategies with local conservation groups and water suppliers, and to incorporate other key players within the region.

The Town has implemented a series of regulations to ensure the quality of the potable drinking water supply that is obtained through the Town South Shore Wells and the aquifer recharge areas, which supply the suppliers in town. Many of these measures have been undertaken within the past several years.

\section{Subdivision Regulations}

In addition to the zoning ordinance, Town subdivision regulations have proven to be an effective regulatory device in groundwater protection. According to the South Kingstown Subdivision and Land Development Regulations, the Town Planning Board may require a developer to prepare an environmental impact statement (EIS) for major subdivisions being constructed in close proximity to natural systems. The definition of natural system includes groundwater resources. However, development within a delineated wellhead protection area or within the overlay district does not necessarily obligate a developer to prepare an EIS. 
Waste Water Management Program

The Town of South Kingstown is currently in the process of developing a comprehensive waste water management program. The program will include the following elements:

- A waste water management study to identify specific relevant issues relating to past and future practices

- Development of an ISDS inspection and maintenance program

- Establishment of a Community Assistance Program to identify and administer available loan/grant programs to assist homeowners with the repair and/or replacement of failed systems

- Development of a GIS base mapping system to be coordinated with data pertaining to various waste water management functions

- Creation of a public education program to develop and disseminate information regarding pertinent waste water issues

Adoption of this legislation could have significant impacts on preservation of groundwater reserves.

Zoning

The Town of South Kingstown has begun to address the issue of groundwater protection in the past through the use of zoning regulations. Specific articles within the ordinance, such as the Groundwater Protection Overlay District, and components within other articles have been adopted because they can serve as effective tools to help maintain drinking water quality.

- Large-lot zoning: Adopted in 1976 and 1984 as a means of protecting groundwater aquifers, rural low density zones are the predominant zoning within the wellhead and recharge areas. The adopted zones consist of two-acre rural residential zones (RR80) and five-acre rural low density zones (RLD200).

Table 13 provides a summary of large lot zoning over each of the aquifers and within the Groundwater Protection Overlay District. As indicated, the majority of the land in each area is designated as two or five acre residential lots.

Table 13: Large lot Zoning over Groundwater Recharge Areas

\begin{tabular}{lcccc}
\hline Aquifer/Zoning & Number of Lots & As \% of Total Lots & Acreage & As \% of Total Lots \\
\hline \hline Chipuxet & & & & \\
R80 & 1 & $1 \%$ & 6 & $1 \%$ \\
RR80 & 448 & $37 \%$ & 2469 & $38 \%$ \\
RLD200 & 62 & $5 \%$ & 1741 & $26 \%$ \\
Total Large Lot & 511 & $42 \%$ & 4216 & $64 \%$ \\
\hline Mink Brook & & & & \\
R80 & - & - & - & - \\
RR80 & 137 & $79 \%$ & 715 & $54 \%$ \\
RLD200 & 25 & $14 \%$ & 309 & 23 \\
Total Large Lot & 162 & $93 \%$ & 1024 & $78 \%$ \\
Factory Pond & & & & \\
R80 & - & - & - & \\
RR80 & 89 & $15 \%$ & 295 & $24 \%$ \\
RLD200 & 73 & $12 \%$ & 602 & $48 \%$ \\
Total Large Lot & 132 & $28 \%$ & 897 & $72 \%$ \\
Source: Town of South Kingstown Database & & &
\end{tabular}


- Performance Standards: Article 13 of the South Kingstown Zoning Ordinance defines performance standards for commercial and industrial uses. The regulations cite limits not to be exceeded as they relate to toxic emissions, including liquid waste. The standards were established in accordance with those recommended at the state and national levels. There are no performance standards specific to recharge areas or the overlay district. A complete copy of Article 13 is included as Appendix B of this document.

- Water Bodies/Wetlands: Section 308 of the Zoning Ordinance requires that no sewage disposal system, disposal trench, disposal bed, cesspool, seepage pit or other facility designed to leach liquid wastes into the soil shall be located within 150 feet of a freshwater wetland or coastal wetland, except by the granting of a special use permit from the Zoning Board of Review. This requirement is more strict than the State regulation that provides for a minimum 50 foot setback between disposal systems and wetlands.

Section 308 also requires that there be a minimum three foot separation between the bottom of the septic system and the seasonal high water table. The Zoning Ordinance requires that detailed soil morphological characteristics be submitted to document existing conditions. An applicant may deviate from the three foot separation only if granted a special use permit from the Zoning Board of Review.

All applications seeking relief under Section 308 must submit detailed information documenting existing site conditions. These include: location of all drinking wells within 200 feet of the proposed ISDS; detailed soil morphology to a depth of four feet; presence or absence of fragipan; depth to water table; surveyed wetland edge within 175 feet of a proposed leach field; and location of coastal features, if applicable.

- Development Pacing and Phasing, Article 23 of the Zoning Ordinance, was adopted in July 1996 and addresses groundwater protection through the goal of minimizing burdens on natural resources. The provisions within the legislation become effective once the 320 dwellings threshold is exceeded by 10 percent in a 24 month period.

The quota will assist in groundwater protection by limiting the effects of new residential development on groundwater. Such provisions will be in place until the Town can take remediative or mitigative steps. Such actions will entail the best means of servicing growing populations with potable water while ensuring the availability of such water supplies.

During periods of rapid town growth, permit applications for developments other than those comprising residential dwelling units will be required to document town-wide effects of the proposed development. Documentation must include the effects on town water supplies and on the nitrogen and phosphorous assimilative capacity of groundwater if the development will not be serviced by public sewers.

- The Soil Erosion control measures were adopted in July 1996 as an amendment to Article 3 of the Zoning Ordinance. The legislation requires sediment control plans for construction of new single, duplex, or multi-family detached structures. Expansion of any existing structure of more than 1,000 feet in ground coverage also requires a sediment control plan. Additionally, new earth removal operations must submit a soil erosion and sediment control plan to the Zoning Board of Review before a permit will be issued. 
The plan must comply with the standards provided in the Rhode Island Soil Erosion and Sediment Control Handbook. The components of the plan must include four central components that will establish the extent of soil erosion and sedimentation resulting from proposed activities and mitigative/restorative efforts to be undertaken by the developer.

- Groundwater Protection Overlay District: By far the most effective and progressive tool adopted by the Town to preserve groundwater quality is the Groundwater Protection Overlay District (GPOD). Adopted in 1991 as Article 20 of the Zoning Regulations, the overlay district places increased restrictions on land uses and activities within parcels of land located over the groundwater recharge areas. The regulations established through the GPOD Ordinance apply in addition to the regulations of the underlying zoning district.

The overlay districts correspond directly with the groundwater aquifer and recharge areas for the Queen and Chipuxet aquifers, the Mink Brook area, and a 1,994 acre area around Factory Pond.

The GPOD Ordinance limits activities and uses of potential threat to the quality of the town's potable water supply. In response to the need to monitor and regulate such activities, the ordinance establishes site design standards for residential and commercial construction. Specific uses are also prohibited from the overlay districts. The legislation also provides guidelines for aboveground and underground storage of hazardous wastes, stormwater runoff, ISDS installation, and earth removal.

Drainage requirements as established through the GPOD Ordinance apply to paved parking areas, public and private streets, loading and storage areas, and other impervious surfaces. However, single lot one- and two-household residences as well as streets serving residential compounds and minor subdivisions are exempt from these requirements.

To assess the impacts of these exempt developments, the newly constructed residential compounds and minor subdivisions, the Planning Department conducted an inventory of new construction within the GPOD since 1991. Of the subdivisions completed in the past five years, residential compounds and minor subdivisions comprised less than one percent of all development town-wide and a minute fraction of development over the groundwater protection area. Exemption of these two types of developments from the zoning regulations therefore has not posed a threat to groundwater resources during the past five years.

Each of the above requirements for management techniques over recharge areas follow state and national guidelines for best management practices.

\section{Town Non-Regulatory Measures}

The Town of South Kingstown also sponsors and has become involved in programs that seek groundwater protection efforts through non-regulatory measures. For each of the following the Town actively encourages local citizen involvement.

\section{Conservation Easements}

The South Kingstown Land Trust is the most proactive organization in securing conservation easements in the town. As of November 1996, the Land Trust owned thirty-eight properties town-wide, thirteen of which lie within or border an overlay district. The total acreage of land owned by Land Trust is more than 600 acres, 300 of which were secured through easements. 


\section{Emergency Response}

The Town of South Kingstown developed a Hazardous Materials Emergency Response Plan to meet statutory federal requirement (SARA Title III). The plan is an annex to the Town's Emergency Operations Plan. It identifies responsible parties, outlines various emergency condition scenarios, identifies control centers and coordinators, and details protective response procedures.

Members of the South Kingstown Police Department also receive training in hazardous materials management while in the State Police Academy. This instruction is supplemented by attendance at State-sponsored workshops while active officers. Officers also have continuous access to the FEMA-prepared Guide to Hazardous Materials.

Such a plan is imperative to protecting water supplies in South Kingstown because portions of Route 1, Route 108, and Route 138 overlay groundwater aquifers and serve as transportation routes for hazardous materials. The South Kingstown Water Supply Board, comprised of representatives from South Kingstown Water Department, United Water and Kingston Water, is responsible for determining possible effects of a spill contaminating public water supplies. This joint coordination supplements the individual suppliers' plans for emergency management, as shall be discussed below.

\section{Farm, Forest, Open Space Program}

The Farm, Forest, and Open Space tax status is part of a State program prepared by the State under RIGL Chapter 44-27. The program's intent is to maintain Rhode Island's agriculture and forest land by allowing for use value assessment. Such assessment is based on the undeveloped value of a given parcel rather than its "highest and best" use possible.

DEM is the entity charged with administering the program at the state level, and the Town tax assessor oversees the program in South Kingstown. Once an individual applies for and receives designation in this tax status, the individual is responsible for maintaining the property or parts thereof as undeveloped for fifteen years. Failure to meet this requirement results in a penalty fee.

The assessors office distributes information about the program in the annual tax bills and at the ten-year property revaluation. To date, twenty-seven (27) lots located over the recharge areas and within the overlay district are enrolled in the program. This comprises a total of 621 acres, or nine percent $(9 \%)$ of the total land overlying the town's three groundwater aquifers.

\section{Land Acquisition}

Acquisition of land near wellheads and over groundwater aquifers involves several local entities. Included among these are the Town, local water suppliers, the Nature Conservancy, and the South Kingstown Land Trust. During the past several years, concerted efforts on the part of all aforementioned parties has resulted in acquisition of land overlying groundwater reserves.

In December 1991, the Town and the Nature Conservancy purchased a 24 acre parcel within the Factory Pond wellhead protection area. Funding for the property was secured through the DEM administered Water Quality Protection Fund.

More recently, in May 1996, the South Kingstown Land Trust in cooperation with United Water, acquired a 47 acre parcel over the Mink Brook Aquifer. The purchase agreement conveys title of the property to the South Kingstown Land Trust and a conservation easement to United Water. Funding made available through the Public Drinking Water Act served as the financing mechanism. 


\section{E. Water Supplier Protection Efforts}

Each of the four water suppliers in town have instituted programs geared to protect the water provided to local residents. Some of the programs target water protection at the wellhead level, as in acquisition of properties over wellhead and recharge areas, whereas other programs ensure that water supplies do not become contaminated in distribution. Augmented by state and local strategies, the following programs currently are and can be effective at ensuring future quality of local water supplies.

\section{Kingston Water District}

Kingston Water District is protecting the potable water supply through several different strategies. The company's Water Quality Protection Plan, included as Appendix K of the District's Water Management Plan, outlines future land purchases by means of the Water Quality Protection Fund. Most of the parcels overlaying the South well recharge area are owned by the State, Kingston Water, or United Water. Such ownership will preclude future contamination resulting from incompatible uses in these tracts. Several lots are homesites and others are wetlands. However, two parcels in the recharge area are privately owned and are not yet developed. Kingston Water intends to purchase the parcels at a future date.

A second strategy for water protection to which Kingston Water District has been a party is the installation of sewer and public water to the West Kingston Industrial area. As discussed in Section II, the Industrial Area overlays the Chipuxet Aquifer. Kingston Water has cooperated with the Town to provide water to this area. Expected completion date of the project is December 1996.

As with all the suppliers in South Kingstown providing 50 millions gallons or more of water annually, KWD prepared an Emergency Response Action Plan in accordance with State regulations. The plan outlines procedures staff should follow in the event of an emergency or a disaster. Included are components applicable to water contamination, equipment failure, and storms. KWD completed the plan in 1994.

\section{South Kingstown South Shore Wells}

South Kingstown Utilities Department is the primary entity charged with overseeing protection of the Factory Pond wellfields. Central to their efforts is the ownership and management of 13 acres of land around the wells. The Town purchased an additional 47 acre parcel in 1994 to further increase the Town's ability to regulate uses around the wellfield.

The wells' close proximity to Route 1 is of concern because of the potential for contamination from a hazardous waste spill and non-point source contamination stemming from highway stormwater runoff. The Town's Emergency Response Plan, as discussed previously, addresses appropriate responses in the event of a highway spill. In addition to this plan, the Utilities Department prepared a separate guidance document for emergency response for the South Shore system.

To mitigate contamination from stormwater runoff, the Town Utilities Department is working in conjunction with the Rhode Island Department of Transportation to conduct a study and preliminary design for a highway stormwater management system. Funding was provided through the Federal Highway Administration and plan completion date is Fall 1997.

\section{United Water Rhode Island}

United Water outlined the following strategies for groundwater protection in their Water Supply Management Plan. Both past efforts and future intentions were included in the plan.

United Water owns and controls large parcels of land around the Tuckertown and Howland wellfields. These lots under their control amount to 30 acres in total. In addition, United recently 
acquired 47 acres of prime agricultural land in the vicinity of their wells. The sale was secured through the involvement of the Town and the South Kingstown Land Trust.

A key component of the company's protection strategies entails public education and the company has actively engaged in customer education for several years. Most efforts strive to increase customer awareness of simple conservation strategies as well as the role of United Water in providing safe water. The primary means of outreach has been through notices enclosed in customer bills.

\section{University of Rhode Island}

The University of Rhode Island installed backflow preventors, which prohibit reverse flow of water from receptacle and tanks into the distribution lines. Most backflow preventors were installed since 1990. Device installation is particularly important at URI because of the many laboratories on campus where toxic chemicals are commonly used. Without appropriate measures, such as the backflow preventors, chemicals could easily contaminate water supplies. According to the Water Systems Operations and Maintenance Manual guide for the University Facilities Department, all backflow preventors are tested immediately upon installation and at least once annually thereafter.

The South Kingstown Comprehensive Plan outlined the Town's commitment to preventing future contamination of groundwater reserves. Part of this is the creation of the Chipuxet Aquifer Authority, of which each of the water suppliers is a member. The organization is advancing groundwater protection strategies over the Chipuxet Aquifer. An important component of their efforts is the identification of other sources of supply to the Chipuxet as a means of preventing unknown contamination of this source.

The University's Emergency Response Plan is incorporated in the Facilities and Operations Manual. It outlines appropriate procedures and responses in the event of an emergency involving the water system. 


\section{RECOMMENDATIONS FOR FUTURE ACTION}

\section{A. Education}

Policy: The Town should undertake a comprehensive public education program to develop and disseminate information regarding protection of ground water resources and related sensitive environmental receptors to ensure long-term potability of South Kingstown water supplies.

Actions: Develop a variety of programs and strategies to reach district groups in town. Central to effective education will be inclusion of homeowners, business owners, and professional farmers.

1. Homeowners

Develop an outreach strategy to increase awareness among local homeowners of the threats to groundwater resulting from failing or improperly operated septic systems.

Essential components should the include provision of literature explaining the need for ISDS inspection and maintenance, particularly in close proximity to wetlands, surface water, and groundwater resources. The DEM Division of Groundwater and ISDS provided the Town with an information packet for use in educating local residents about groundwater issues. The Town should develop a strategy to effectively distribute the information to residents. Materials should also include items that will remind residents to check the individual sewage disposal system to prevent system failure. An effective means might be through the use of refrigerator magnets with a printed message.

Responsible Parties: Planning Department, Conservation Commission

Identify funding sources to provide workshops for homeowners to attend the URI Cooperative Extension Services On-site Wastewater Training Center. The Center offers programs designed to educate homeowners on the importance of and procedures for ISDS maintenance and includes a component on alternative, nitrogen-reducing systems.

The Public Drinking Water Act of 1987 provides funding for water suppliers to engage in protection efforts. Approximately 35 percent of funds gained through the assessed surcharge may be used for efforts other than land purchase. The Town should consult local water suppliers to develop a strategy for educational funding.

Responsible Parties: Planning Department, Conservation Commission, Community Water Suppliers

Cooperate with DEM Division of Agriculture to develop strategies to reach homeowners concerning unmanaged use of chemicals in residential grounds maintenance. A primary focus must entail education of homeowners of the best management practices for fertilizer application.

DEM Division of Agriculture is undertaking an ambitious campaign to curb the overuse of fertilizers and lawn chemicals by homeowners. Division staff have already met with South 
Kingstown Planning Department staff and representatives from several of the public water suppliers. The Division is actively encouraging Town and supplier cooperation in these efforts.

Responsible Parties: Planning Department, Conservation Commission

Work with URI Cooperative Extension to involve local residents and neighborhood associations in the pilot Home*A*Syst Program.

The Home*A*Syst program (Home Assessment System) was designed by the Cooperative Extension to train Rhode Island residents to minimize pollution threats to the environment from sources in and around the home. Past participants have created wellhead protection areas around private wells, learned about proper septic system maintenance, inspected underground storage tanks on the property for leaks, and determined appropriate use, storage, and disposal of lawn chemicals. A wide variety of local and state organizations partner with Cooperative Extension in the program. The program poses an ideal means of resident education and will enable the Town to establish closer connections with other parties concerned with groundwater protection.

Responsible Parties: Planning Department, Conservation Commission

Household Hazardous Wastes

In conjunction with DEM Division of Waste Management, educate local residents about proper disposal of common household articles such as mothballs, flea collars, household cleaners, and medicines. All are considered hazardous waste and improper disposal can adversely affect groundwater quality. Inform of Fields Point disposal site in Providence and work with DEM to reinitiate drop-offs at Rose Hill Transfer Station.

Responsible Parties: Public Utilities Department

2. Businesses

Expand educational efforts to reach business owners of best management practices they can employ to protect groundwater supplies. Of importance will be to define and encourage compliance with the standards required by the Town's Groundwater Protection Overlay District legislation. The town should focus on all businesses located within the wellhead protection areas, with particular attention to industrial and commercial operators in West Kingston.

Responsible Parties: Planning Department, Planning Board

3. Professional Farmers

Cooperate with DEM Division of Agriculture and URI Cooperative Extension in promoting groundwater education and best management practices (BMPs) for local agricultural operations.

Responsible Parties: Conservation Commission

4. General Public 
Place signs in strategic locations overlaying groundwater aquifers to inform local residents and visitors of the natural resource. Follow design guidelines as established by DEM and Rhode Island Department of Transportation.

The State is installing signs on Route 1 within the Factory Pond recharge and wellhead protection area. Signs should also be placed in areas that overlay both the community and noncommunity wellhead protection areas.

Responsible Parties: Public Works Department

\section{B. Legislation}

Policy: The Town should use its regulatory power to ensure continued quality of South Kingstown water supplies.

Actions: Supplement non-regulatory strategies and existing legislation with regulations to alleviate currently unaddressed problems:

Adopt a Waste Water Management District. The legislation should incorporate the following programs:

- Mandatory inspection to prevent failure of systems

- Financial assistance for homeowners with failing systems

- Educational components for residents within the WWMD

- GIS mapping to maintain an inventory of properties within the WWMD

Responsible Parties: Planning Department, Conservation Commission, Town Council

Investigate the possibility of a nutrient loading ordinance for new residential developments within the Groundwater Protection Overlay District (GPOD) and other environmentally sensitive area (e.g. Salt Pond region). Restrict new development that surpasses the nutrient loading levels until the developer and/or the Town has determined steps to mitigate the effects of such proposed development.

The Town of Falmouth, Massachusetts has regulations to control nutrient loading (the process of compounds entering waters from non-point sources such as septic systems, lawn fertilizers, and road drainage) into the town's fresh and coastal waters. As part of Falmouth's subdivision and review process, the planning board requires developers to determine the nutrient loading of the proposed subdivision compared to the carrying capacity or critical levels of receiving waters. The developer is required to determine the probable impacts of the subdivision on water systems, either surface or groundwater.

Responsible Parties: Planning Department, Conservation Commission, Town Council

Examine existing industrial performance standards and consider a requirement for more stringent standards for industrial users seeking building permits for new or expanded structures in any site overlaying a groundwater aquifer. This is particularly important in the West Kingston Industrial Area. 
Explore the feasibility of mandatory alternative technologies for septic systems (ISDS) in fragile ecosystems, including in wellhead protection areas.

The Coastal Resources Management Council recently amended their regulations to require alternative septic systems within 200 feet of coastal areas. The legal basis for such action exists and needs further research and documentation by the Town.

Responsible Parties: Planning Department, Conservation Commission, Town Council

Continually evaluate the ability of current regulations to protect groundwater supplies, particularly in consideration of contemporary research and findings regarding natural resource protection.

In addition to reviewing current regulations and/or strategies regarding CONSERVATION EASEMENTS, CLUSTER ZONING, PURCHASE OF DEVELOPMENT RIGHTS, and LARGE-LOT ZONING, a thorough assessment of alternative tools for groundwater protection should also incorporate consideration of TRANSFER OF DEVELOPMENT RIGHTS (TDR). TDR programs typically permit owners of land in development-restricted areas, called "sending districts," to sever the development rights form their property and sell those rights to owners in specified "receiving districts." The Town of South Kingstown could consider designation of specific areas within groundwater recharge areas as sending districts and encourage growth in the denser villages of Kingston, Wakefield, and Peace Dale, and other less sensitive regions of town. This strategy would be in accordance with the core-periphery pattern of desired development identified in the Comprehensive Plan (Land Use Element, page 43; Goal 4, page 79).

Responsible Parties: Planning Department, Conservation Commission, Planning Board

\section{Cooperation}

Policy: The Town recognizes the need to coordinate protection efforts with other entities because of the interdependent nature of the groundwater reserves in the Pawcatuck Watershed.

Actions: Expand Town involvement with State agencies, neighboring municipalities, water suppliers and non-profit organizations to promote long-term preservation of groundwater supplies.

1. Regional Cooperation

Work with The Pawcatuck Watershed Partnership to expand regional cooperation efforts among the towns within the Pawcatuck Watershed. Efforts should focus on questions of land use and development within the Watershed and educational strategies for each of the communities. 
The Partnership is an evolving entity of diverse groups and interests. So far, participating organizations include Rhode Island DEM, Connecticut Department of Environmental Protection, Wood-Pawcatuck Watershed Association, US Fish and Wildlife Service, and local conservation districts. The underlying goals of the Partnership are to identify new ways to use, manage, and protect the natural resources of the Watershed. This entity provides an ideal vehicle through which the Town of South Kingstown can develop innovative approaches in partnership with the other localities dependent upon the Watershed for present and future needs.

Responsible Parties: Planning Department, Conservation Commission

2. Cooperation and dialogue with water suppliers

Remain informed of issues facing suppliers in town through increased dialogue, particularly with non-community suppliers. Encourage joint protection strategies and a forum to voice shared concerns.

In addition to communication among the primary providers of water in town, another appropriate mechanism for dialogue will be the regional forum discussed above. This will provide simultaneous discussions regarding town concerns within the regional context.

Responsible Parties: Planning Department, Conservation Commission, Water Suppliers 


\section{IMPLEMENTATION}

According to the DEM Wellhead Protection Program Guidelines, the implementation component of the plan must cover a period of five years. Because the Town has already made headway in the arena of groundwater protection through the passage of the Groundwater Protection Overlay District, extension of sewers to the West Kingston Industrial area, and has already incorporated necessary regulations, such as of USTs, into existing laws, the following actions predominantly focus on educational efforts. Although questions of funding for education are a legitimate concern and can prolong initial efforts at implementation, strategies designed to educate will generally take lesser time to accomplish than will those requiring legislative adoption. Thus, many of the following programs can be adopted and implemented within a year or two.

South Kingstown is particularly fortunate to have the University of Rhode Island in close proximity. University scientists and educators have historically assisted the Town in various matters. The Town should capitalize on this asset in developing the educational programs.

\begin{tabular}{|c|c|}
\hline Year & Strategy \\
\hline 1997 & $\begin{array}{l}\text { Adopt the Wellhead Protection Plan } \\
\text { Advance regional cooperation efforts for wellhead protection (on-going) } \\
\text { Increase discussions with and among local water suppliers (on-going) } \\
\text { Arrange for household waste drop-off site in town (on-going) }\end{array}$ \\
\hline 1998 & $\begin{array}{l}\text { Adopt a Waste Water Management District } \\
\text { Establish elements for educational outreach to homeowners to include the } \\
\text { following (on-going): } \\
\text { Homeowner outreach for septic-related issues } \\
\text { Workshops at On-site Wastewater Training Center } \\
\text { Residential lawncare education with DEM } \\
\text { Home*A*Syst Program } \\
\text { Cooperate with DEM to promote BMPs for professional agriculture } \\
\text { Evaluate current regulations for effectiveness; assess opportunities to revise } \\
\text { and/or adopt additional strategies (e.g. TDR program) }\end{array}$ \\
\hline 1999 & $\begin{array}{l}\text { Signage in wellhead protection areas } \\
\text { Advocate best management practices for business owners } \\
\text { Review options for industrial loading ordinances } \\
\text { Examine feasibility of alternative ISDS regulations in recharge areas. }\end{array}$ \\
\hline 2000 & $\begin{array}{l}\text { Examine existing Industrial Performance Standards within WHPAs. Adopt new } \\
\text { standards for new or expanding industrial uses }\end{array}$ \\
\hline 2001 & \\
\hline 2002 & \\
\hline
\end{tabular}

Although many of the strategies can be implemented in the first several years following adoption of this plan, these educational efforts will be on-going. Programs must be tailored in future years to reflect the changing needs of the town's populations, any alterations in groundwater supplies and availability, and most importantly, to best educate the local populations.

Programs should be evaluated following implementation to ensure that educational goals are being addressed. As such, the educational programs will require concrete evaluative criteria. 


\section{REFERENCES}

Case Studies in Wellhead Protection: Ten Examples of Innovative Wellhead Protection Programs. 1992. United States Environmental Protection Agency Office of Ground Water and Drinking Water.

Code of Ordinances of the Town of South Kingstown. As amended through November 27, 1995.

Gold, Arthur J., William R. DeRagon, W. Michael Sullivan, and Jerrell L. Lemunyon. 1990. Nitratenitrogen Losses to Groundwater from Rural and Suburban Land Uses. Journal of Soil and Water Conservation. 45:2 (March-April) 305-310.

Haviland, Robert. 1996. Department of Health Division of Water Quality. Personal Communication, 26 November.

Kingston Water District Water Management Plan. 1993. Prepared by Wiley Archer P.E. Water System Consulting, Providence.

McCann, Alyson and Arthur J. Gold. 1991. The Pawcatuck Watershed Project. University of Rhode Island, Department of Natural Resources. Cooperative Extension Fact Sheet, No. 90-25.

Morin, Stephen and Jacquline McGrath. A Citizen's Guide: Farm, Forest and Open Space Act. Rhode Island Department of Environmental Management and URI Cooperative Extension.

Rhode Island's Management Plan for the Protection of Ground Water from Pesticides and Nitrogenous Fertilizer, Draft Copy. 1996. RIDEM Division of Agriculture.

Rhode Island Wellhead Protection Program Biennial Report. 1995. RIDEM Division of Groundwater and ISDS.

Stoloff, Neil. 1991. Regulating the Environment: An Overview of Federal Environmental Lan: Dobbs Ferry, NY: Oceana Publications.

Sullivan, W. Michael. 1996. Associate Professor Plant Science, University of Rhode Island. Personal Communication. 3 December.

The Pawcatuck Watershed Partnership. Project description. 1997.

Town of South Kingstown Comprehensive Plan, 1992. As amended through December 11, 1995.

Town of South Kingstown Utilities Dept. South Shore and Middlebridge Systems Water Supply Management Plan. 1994. Prepared by Camp, Dresser, and McKee.

Town of South Kingstown Zoning Ordinance. Adopted May 1994, with revisions through July 22, 1996.

Town of South Kingstown Subdivision and Land Development Regulations. Adopted February 1995, with amendments through August 13, 1996.

United Water Rhode Island Water Supply Management Plan. 1996. Prepared by Pare Engineering Corp. Lincoln, RI.

University of Rhode Island Facilities and Operations Manual. 1994. Department of Facilities and Operations.

USTs: A Guide for Local Officials. 1988. Town of South Kingstown Planning Department.

Wellhead Protection Programs: Tools for Local Governments. 1989. United States Environmental Protection Agency Office of Water.

Witten, Jon, and Scott Horsley. 1995. A Guide to Wellhead Protection. Chicago: American Planning Association Planning Advisory Service Report Number 457/458. 
Appendix B: The Groundwater Protection Overlay District, Article 20 of the South Kingstown Zoning Ordinance 


\section{ARTICLE 20 \\ GROUIDWATER PROTECIION OVERTAY DISTRICT}

\section{Section 2010 - EBtablisbment of District}

There is hereby established a Groundwater Protection overlay District (GPOD) which shall be the area defined as lots of record which are indicated as the GPOD on the Official Zoning Map of the Town of South Kingstown. The GPOD is superimposed over any other zoning district established by this ordinance. The regulations imposed by the GPOD shall apply in addition to the regulations of the underlying zoning district. In the event of a conflict of inconsistency between the regulations imoosed by the GPOD and those imposed by the undezlying zoning district, the regulations imposed by the GPOD shall govern.

\section{Section 2011 - Puppose}

The purposes of this Atticie are to protect, preserve and maintain the quality and supply of cercain groundwater reservoirs in the Town of south kingstown tinrougin regulation of land use and certain activicies in the areas over the groundwater reservoirs and critical portions of their groundwater recharge area. It is furcher the intent of this Arvicle to permit the use of Iand within the GDOD for agricultural purposes, and to encourage the use of farmiand in a manner which is consistent with protection of surface and grounowater resources.

\section{Section 2012 - Delineation of Disteicts}

The Groundwater Protection Overlay Distzict is intended =0 regulate uses within the following areas:

A. Groundwater reservoirs are the highest yielding portions of the state's stratified arift aquifers (saturated thickness greater than 40 feet ano transmissivity greater than 4000 feet souared per day) that are capable of serving as a significant source of public suppiy; and,

B. Critical portions of the recharge areas to the above groundwater Ieseryoirs, as defined by the Rhode Island Department of Environmental Management (RIDEM) as groundwater classified as GAA; and that porcion of the Beaver-Pasquiset recharge area within South Kingstown; anc,

C. Area acjacent to Factory Pond defined by RI DEM as the area of contziburion to existing public water supplies. 


\section{Section 2013 - References}

Identification of areas witing the GPOD have been made by reference to maps and studies prepared by the following:

A. Ground-Hater Resources of the Ringston Ouadrangle, Rhode Island, by the Rhode Island Development Council, Geological Bulletin No. 9, 2956.

B. Availability of Ground Water, Opper Pawcatuck River BaBin, Rhode Island, Geological Survey Water-Supply Paper 1821 , prepared in cooperation with the Rhode Island Development Council and the Rhode Island Water Resources Coordinating Board, 1966.

C. Groundwater Ouality Reculations, materials used in the development of the RI DEM groundwater regulations, pursuant to Chapters $46-13.1,46-12,42-17.1$ and $42-35$ of the General Laws of Rhode Island, as amended.

D. Bydrology, Water Ouality, and Groundwater Development Aterpatives in the Chipuxet Groundwater ReservoiI, R. I., U.S.G.S. Water Resources Investigation Report 84-4254, by Herdert E. Johnston and David C. Dickerman, 1985.

Section 2020 - Permitted Useg

All uses indicated in Section 220 or Article II as permitted uses $(Y)$ and special permit uses (S) in the underlying zoning isstrict are permitzed or conditionally permitsed in the Groundwater Protection Overlay District, with the exception of prohibited uses and activities as further provided in section. 2021. Also permitced are uses or stzuctures accessory to any permitzed use.

\section{Section 2021 - Probibited Uses and Activities}

The following principal uses and activities are prohibiced in the GPOD :

1. Any use prohibited (N) in the underlying zoning districts;

2. General automotive service and repair shops, including repair to motorcycle, marine, aircraft, recreational vehicles, farm or lawnmowing equipment, or other similar vehicles and equipment. Included among these uses are establishments which sell, store, lease or rent such equipment and wilch include service and repair as accessory acrivities. Non-commercial repair work, or repair work incidental to a permitted use, is not prohibited.

3. Gasoline service stations (minor repairs only); 
4. Automobile body siops;

5. Lawn \& garden supply stores;

6. Welding shops; sheet metal shops; machine shops;

7. Aucomobile junk yards; junk and salvage yards of any Iype;

8. Fuel dealers, oil a bottled gas sales and service; and oper lot storage of suci iuels;

9. Metal plating, finishing and polishing, including jeweiry manufacturing;

10. Dry cleaning plant (not including pick-up);

I1. Beautician, barber or cosmetologist, except if serviced by public sewe=s;

12. Commercial wood preserving and Eurnizure painting or zefinishing;

i3. On site photographic processing or printing;

14. Incinerators, sanivary landfill sites, solid waste disposal łacilities, solid waste tzansfer stations, resource recovery or recycling facilities, injection wells, and hazarcious waste management Eacilities;

13. Iand disposal of seprage or sewage sludge, inclucing composted industrial sludge. Not prohibited is the application of wastewatez Ereatment facilizy composted sludge, appiied according to the RI Department of Envizonmental Management "Rules and Regulations Pertaining to the Treatment, Disposal, Utilizarion, \& Transportation of Wastewater Treatment Facility Slucge," 1991.

16. All uses which involve the use, storage or generation of hazarcious or coxic waste or materials or other toxic pollutants as defined herein. Provided, however, that minor or insignificant ouanticies of such materials may be stored on the premises of any lawful use, if, in the opinion of the Building Official, the presence of such substance does not constitute a potential for degradation of surface or groundwater resources in the area and such substance is contained in a suitable storage area. In making a determination of the presence of significant quantities of such materials, the Building Ofiicial shall obtain the written opinions of the RI Department of Environmental Management (DEM) Division of Air and Hazarcous Materials, the RI DEM Division of Agriculture, or the RI Pesticide Coordinator, as applicable. Insignificant quantities of hazardous materials may be construed as tinat 
which is necessary for the operation of a farm, residence, office, or business including the operation of equipment, vehicles or other mechanical systems necessary for the operation of a permitted use;

17. Underground storage tanks as defined in Secrion 1772 are prohibited. However, storage tanks used for storing home hearing oil (No. 2 fuel oil) and serving a one or twohousehold dwelling are permitted if the following conditions are met:

a) the tank capacity does not exceed 300 gallons (per dwelling unit); and,

b) the tark is located in a basement or cellar, is above the surface of the basement floor and the basement floor is constructed of concrete or contains a membrane liner capable of́ containing spills;

- or -

c) the tank is located above ground or in a basement having a dirt floor provided the following criteria are met:

- grovision is made to protect the tank Erom the elements. Rustproofing sinall be applied to all tank surfaces;

- the tank shall be securely anchored; and, - the tank shall be placed onto a concrete foundation capable of supporting the rank. The foundation must be larger than the size of the lank in length and width to prevent leaks onto pervious surzaces.

All storage tanks of 300 gallons capacity or greater and which are located above ground shali be governed by the provisions of Section $2030(2)$. Above ground storage tanks which exceed 10,000 gallons per lot are permicted only by the granting of a special use permit by the zoning Board of Review. In reviewing said special use permit the Zoning Board shall require an applicant to submit a detailed report by a gualified specialist on the design and construction of storage tanks and containment devices, and shall consider the potential impact on groundwater in the event of leaks, spilis, fires, maintenance, deliveries and other such activities and events.

18. Storage of road salt and deicing materials which are not covered by a roof and located on an impermeable base;

19. The parking of venicles for the storage or delivery of fueI oil or other hazardous or toxic materials for a period exceeding two (2) hours in any twenty-four (24) hour 
period. This shall not prohibit the use of vehicies for delivery of fuels or for application of fercilizers, pesticides, or herbicides to any use permitted by this ordinance ;

20. Vehicie washing shop (inciuding automatic);

21. Motor freight terminal;

22. Eish hatcheries.

23. Textile Mill Products - Use Code 22 (Amended 12/I3/93)

\section{Section 2030 - Site Desion StandaIds}

The following site design and construction standards shall be reouired for all new and substantially reconstructed uses, otiner than one or two household residential uses within the GPOD, established after the effective date of this Article. "Substantial reconstuction" shall mean the improvement, alterazion or replacement of more than 30 per cent of the floor area or land area of the existing use. Site design and construction standaras shall follow, where apolicable, the zecommendations and guidelines as provided in the following documents: (1) The Rhode Island Soil Erosion and Sediment Control Handbook, 1989, as amended; (2) The Rhode Island Department of Environmental Management's Recommendations of the Stormwater Management and Erosion Control Committee Regarding tine Development and Implementation of Technical Guidelines for Stormwater Management, 1988, as amended; and (3) Controlling Urban Runoj̇: À Practical Manual for Planning and Designing Urban B.M.P.s, by the Metropolitan Wasinington Council of Governments, 1987, as amended.

2. Storage of hazardous or toxic waste or materials, where permitted, shall be located within a building having roofing, walls, and floor(s) constructed of such materials as to render said building weather tight, so as to prevent leakage of such products or materials inco or onto the ground.

2. Storage tanks for petroleum produces or hazardous or toxic materials excluding portable Euel tanks for farm uses may be located outdoors provided they are located within a containment structure that has an impermeable base and surrounding dike. Such base and dikes shall be constructed of marerial which is both impermeable and compatible with the material being contained. At minimum, the scructure shall be designed to contain 110 per cent of total tank capacity.

Such containment structures shall be covered to procec= ine tanks and prevent accumulation of precipisation witin the dike. Where roofing is not practical, the concainment structure shall be designed with an additional capaci=y 
sufficient to contain precipitation from a 25 -year 24 hour rainfall event. Runoì Erom the containment sinal be controlled by means of pumps, siphons or piping designed to eliminate discharge of contaminated water into the environment in the event of a spill, or have a drain valve which will allow clear stormwater to be manually released as needed.

3. Interior floor drains designed to permit fluid from any interior space to be disciarged into or onto the ground shall be prohibited. Provided, however, that such interior floor drains may be permitted if designed to empty into an above-ground storage tank, capable of completely containing anticipared flows. Such tanks, if provided, shall also be subject to containment provisions specified in Section 2030, subsection 2, above.

4. Dumpsters which are used to store solid wastes shall be covered or located within a roofed area and have drain plugs intact. No washing or rinsing of dumpsters on-site shall ocsur.

5. Rainwater collected upon permanent roofing over 1500 sq. ft. in total area per lot shall be directed into dry wells, injection welis, or underground leaching galleys or otherwise diverted to a permeable ground surłace, so as to encourage recharge of the ground water. Provided, however, that such rainwater shall not be mixed with stormwater runoff from any parking area, roadway, or area subject to contamination from any hazardous or toxic waste or material or petroleum product prior to discharge into or onto the ground.

6. Stormwarer runoff Erom paved parking lots, public and private streets, loading areas, storage and operating areas, and other impervious surfaces subject to contamination from road de-icing materials or petroleum products, shall be:

a) collected and diverted through an oil/water separator prior to disciarge to the environment; and/or,

b) coliected and discharged into "wet" stormwater detention basins capable of achieving water quality enhancement of the Iunorit; and/or,

c) collected and discharged into extended detention dry basins; and/or,

d) civerted toward vegetated filter strips, swales, or riprap lined channels; and/or,

e) diverced inco sand bed Eilcers; and/or,

E) discharged or diverted to other stormwater management facility(s) designed to attenuate runoff and provide 


\section{pollutant removal capabilities.}

The procedure for review of stormwater runoff controls shall be as specified in Section 333 of this ordinance. Provided, however, that said site plans shall also be submitted to the Conservation Commission for their site zeview and advisory opinion. The planning Board shall have the authoricy co approve the design of all such stormwater runoff controls reguired under this Section.

The above stormwater management recuirements shall incorporate best management practices, as that term is used in "Controlling Orban Runoff: A Practical Manual for Planning and Designing Jrban B.M.P.S", and be designed to be effective in poliutant removal sufficient to minimize harmful impacts to groundwate anc surface water resources. They shall be commensurate with the size and nacure of the proposed use.

Provided, however, that the following shall not be required to provide said stormwater management facilities:

a) single or two-household residential uses on a single lot; and

b) streets serving a residential compound or minor subdivision approved by the Planning Board.

7. Garbage disposal systems (in sinks) shall be prohibited in areas not serviced by public sewers.

8. At least twenty (20) percent of the area oi each lot shal I be covered with existing or introduced vegetation.

9. Commercial earth removal, as defined in section 1401 oi this ordinance, excluding construction necessary for new farm ponds, new drainage structures, and new farm roads, shall be subject to the following restrictions in the GPOD:

a) a minimum separation distance of three (3) feet between the bottom of the excavation and the seasonal high water table, as verified by RIDEM, shall be maintained;

b) Tine installation and regular maintenance of permanent soil erosion and sediment control measures, as outlined in the Rhode Island Soil Erosion and Sediment Control Handbook, I989, as revised, shall be required, inclucing permanent revegetation of the land surface upon cessation ö earth removal operations;

c) The provisions of items $a$. and b. Of this subsection as set forth above shall also be deemed to apply to earth removal activilies conducted as part of an approved suodivision. 
10. Any use which would utilize an individual sewage disposal system, or multiple systems, serving the same use, or comination of uses on a lot for which the total maximum daily design sewage flow exceeds two thousand $(2,000)$ gallons per day shali be permitsed, only upon the granting of a special use permit for such ISDS by the Zoning Board of Review. In reviewing said special use permit the Zoning Board shall require an applicant to submit a detailed report by a gualified specialist on the present water quality conditions and the potential impact to ground and surface waters from the proposed use, including the cumlative impacts of sewage discharge over an exrended period of time.

Section 2031 - Maintenance of Facilitieg

All facilities constructed in accordance with section 2030 shall be maincained by the owner so as to assure their ability to function as designed. Failure to properly maintain said Eacilities shall constitute a violation of this ordinance, and is subject to enforcement action by the Town as provided in Article 6 . As a condition of granting a building permit for any such facility, the Building Official is empowered to enter onto the premises in order to inspect said facilivies for the purpose of determining their functionality. 

